\title{
75 years of scientific and technological advances in pastoral agriculture - what will it take to continue to deliver?
}

\author{
J.R. CARADUS \\ Grasslanz Technology Ltd, PB 11008, Palmerston North \\ john.caradus@grasslanz.com
}

\begin{abstract}
Scientific and technological advances are important for any industry to ensure continued improvement in productivity - achieving more output of value per unit of input. Since the majority of New Zealand's pastoral produce is traded internationally we need to ensure that we are the most efficient at growing and producing this produce, whether it is traded as a commodity or as a value added product. The requirement for continued $R$ \& D investment in our agricultural knowledge economy is a prerequisite for continued improvements in pastoral agricultural productivity. In reflection, the major scientific and technological advances that have improved on-farm productivity over the last 75 years are described and the challenge is given to determine how this might continue into the future.
\end{abstract}

Keywords: pastoral agriculture, research and development, technologies

\section{Introduction}

Pastoral agriculture continues to be the major driver of new wealth creation for New Zealand. This is despite the enthusiasm from decision makers and politicians of the 1990s who suggested we should 'surf the knowledge wave' to prosperity. The point they missed was that pastoral agriculture has always been New Zealand's knowledge industry. Our success in international markets has been due to the rapid and effective use of new technologies and innovations by farmers. Over the past 75 years the synergistic interaction between researchers, extension specialists, rural professionals, and innovative farmers has ensured that New Zealand pastoral agriculture production is world leading. Some of this innovation has been lead by farmers but often researchers provided the insight to ensure the most effective use of new technologies.

A recent working paper published by New Zealand Treasury underscores not only the importance of the agricultural sector to overall growth and productivity in New Zealand, but also demonstrates that investment in domestic agricultural $\mathrm{R} \& \mathrm{D}$ has generated an annual rate of return of $17 \%$ over the past 75 years (Hall \& Scobie
2006). They conclude that "our findings typically support the argument that the stocks of domestic knowledge are positively associated with productivity growth. The very existence of foreign knowledge may be a necessary condition for achieving productivity growth in a small open economy. However, in no way could it be argued that it is sufficient. Having a domestic capability that can receive and process the spill-ins from foreign knowledge is vital to capturing the benefits."

While there is no single, widely-accepted measure of innovation, growth of Multi-Factor Productivity (MFP) provides a broad indication. ${ }^{1}$ Table 1 shows that the agricultural sector has outperformed the rest of the New Zealand in terms of productivity growth over the past quarter century $(1978-2001)$.

Table 1 Compound growth rates in Multi-Factor Productivity.

\begin{tabular}{lcc}
\hline & New Zealand (\%) & Agriculture (\%) \\
\hline Value added basis & & \\
1978 to 1992 & 1.1 & 3.7 \\
1992 to 2001 & 1.3 & 2.1 \\
$\begin{array}{l}\text { Output basis } \\
1992 \text { to } 2001\end{array}$ & - & 0.7 \\
\hline
\end{tabular}

Source - Statistics NZ, NZ Treasury

\section{Agriculture - New Zealand's Knowledge Industry}

New Zealand's international competitive advantage in producing agricultural products will be maintained through the ongoing application of innovative technologies and smart business practices leading to increased on-farm efficiencies, productivity, and added value. Much of this accumulated knowledge and technological advance has occurred over the last 75 years.

Proceedings of the New Zealand Grassland Association provide a valuable resource that captures advances both great and small in acquired and applied knowledge and technologies that have ensured that New Zealand agriculture is world leading. The Proceedings also show that the industry has continually sought to improve its productivity. These are detailed in Appendix 1.

${ }^{1}$ MFP measures the increase in output not accounted for by increases in measured inputs such as labour and capital. For national economies, MFP is usually measured on a value-add basis (defined as the net returns to labour and capital after deducting the cost of other inputs), whereas industry-level comparisons across time are often based on output produced. The economics literature notes that MFP measures not only the rate of technological change but also the associated "free lunches" arising from scale economies and externalities between firms, industries and countries. 
The following are some of the more significant advances (details of advances since 1930 are given in Appendix 1):

- Understanding of pasture grazing management

- Animal improvement - high fertility sheep, improved feed conversion efficiency in dairy, development of the first full "New Zealand" breed of dairy cattle based on elite animal genetics

- Plant improvement - use of non-toxic grass endophytes, effective rhizobium strains, improved cultivars

- Subdivision - including the use of electric fencing

- Product harvesting technologies - herringbone and rotary dairies, and electric sheep shears

- Understanding of plant nutrition and the use of fertilisers - aided by aerial topdressing

- Identification of nutrient deficiencies affecting animal health

- Use and adoption of H1 short rotation ryegrass by farmers

- Use of mineral nitrogen

- Nitrification inhibitors

- Animal vaccines

- DNA testing to simplify calf identification

- Electronic identification (ID) ear tags on cows to automate audio alerts, automatically draft cows

- Software for predicting soil response to a range of fertiliser applications so as to minimise nitrate runoff

- Indirect pasture measurement techniques - plate meters, satellite images

\section{The dairy sector}

In the dairy industry, labour productivity measured as cows managed per labour unit has increased by $45 \%$ over the last decade and, when measured as milksolids harvested per labour unit by $65 \%$ (Table 2). Over the last decade the dairy industry has substantially increased milksolids produced per ha and per cow (Table 2).

In the 1940s, the leading dairy farmers were achieving 250-300 lb milkfat/acre. This is equivalent to about 500 $\mathrm{kg}$ milksolids/ha. The average was approximately $140 \mathrm{lb}$ milkfat/acre (Hunger 1951), compared with the average now of $860 \mathrm{~kg}$ milksolids/ha. This is approximately a two-fold increase over 60 years. Today some leading farmers are achieving close to $2000 \mathrm{~kg}$ milksolids/ha.
The Lincoln University dairy farm which uses little supplementary feed achieves approximately $1700 \mathrm{~kg}$ milksolids/ha; this is a three- to four-fold increase on what was possible 60 years ago.

\section{The meat and wool sectors}

In the sheep industry there has been increased production occurring at a time when labour numbers have decreased (Bray 2004). Sheep farming performance, based on lamb and mutton carcass weights, lambing percentages and wool weights, has improved $35-55 \%$ per labour unit/1000 stock units. This indicates improvements in efficiency of labour through increased use of technology.

The substantial growth in financial returns from sheep in recent years has occurred in spite of the large drop in sheep numbers. It is due not only to increased market demand but to impressive increases in sheep performances that have offset the impact of declining sheep numbers. Remarkable gains that have been made include:

- A $25 \%$ increase in lambing percentage and carcass weight since the 1980s.

- Increased lamb meat production with carcasses which are more suited to high value markets, despite sheep numbers decreasing. Furthermore, this has happened without changes in stocking rate, lambing date, or use of new pastures and only a small change in seasonal slaughter pattern.

- An increase in lamb growth rates by $50 \mathrm{~g} / \mathrm{d}$ since the 1980s - a major change that has not been identified before.

- An outstanding achievement of a $3.5 \mathrm{~kg}$ increase in carcass weight without an increase in fatness.

\section{Grassland Improvement and Management - Our Legacy}

Before 1930, there were no certified cultivars of ryegrass or white clover; fertiliser topdressing was ineffective because of the absence of a good pasture legume; expansion of grassland into difficult areas and soils was impeded by lack of knowledge and know how (Saxby 1954).

A meeting was called by A.H. Cockayne (Assistant DG of Agriculture) on the 19/20 January 1931 with the

Table 2 Changes in on-farm productivity (using both partial and total measures) over the last decade (Caradus 2005).

\begin{tabular}{lccc}
\hline Criteria & $1994 / 95$ & $2003 / 04$ & Change (\%) \\
\hline Cows per ha & 2.48 & 2.75 & +10.9 \\
Milksolids per hectare (kg/ha) & 671 & 889 & +32.4 \\
Milksolids per cow (kg/cow) & 271 & 322 & +18.8 \\
Cows per labour unit & 96 & 140 & +45.8 \\
Milksolids per labour unit & 26016 & 42981 & +65.2 \\
\hline
\end{tabular}


aim of "the betterment of research, investigation, demonstration or instruction in grassland management generally". Twenty one people attended from the Department of Agriculture, Canterbury Agricultural College (now Lincoln University), Massey University, Cawthron Institute and the fertiliser industry (Saxby 1954). In his address, Cockayne called for "a grassland caucus which will dominate grassland research and improvement". This lead to the establishment of the New Zealand Grassland Association and the first meeting was held in Palmerston North on 5 August 1931. It was attended by 28 people.

The Association had a faltering beginning. The depression meant that meetings were planned and then cancelled, and finances were strained; the second meeting did not occur until April 1933. This was a conference in which the President made his address by radio broadcast from his hospital bed, and where there was acrimonious debate over seed certification and the formation of the seed industry. At this conference the first farmer paper was presented and, other than during the war years (1940 to 1946), we have held successful conferences annually ever since. By 1954 we had 784 full members and 127 conference members, a total of 911 which is not very different from today. Interestingly, farmers made up about half the membership (Saxby 1954) then as they do today.

Over the past 75 years the New Zealand Grassland Association has been a focal point for introducing new knowledge and technologies, providing an opportunity for debate and refinement of knowledge, and then uptake by consultants and farmers to improve the productivity of our grassland farming operations. Many of these are summarised in Appendix 1.

Perusal of NZGA conference proceedings indicates that many of the challenges and opportunities facing us today are not new. For example:

- Effective technology transfer and adoption of new knowledge and technologies has always been a challenge. In 1933, Connell commented that there was a need for the social science research to be used to assist with increasing the uptake and adoption of new knowledge and technologies. Callaghan (1935) and Hamblyn (1947) also expressed concerns about extension methodology. Robertson (1980) suggested that the language used by scientist in communicating their results was not conducive to rapid understanding. The effectiveness of discussion groups in raising on-farm production was described by McKenzie (1980). The recurring theme of improving uptake of technologies by farmers was reiterated by Webby \& Sheath (1991), McRae (1992), Garland (1993), MacClean et al. (1997), Manson (1999), Webby (2002), van der Geest (2002), Prewer
\& van Bysterveldt (2004), and Savage \& Lewis (2005).

- National production targets are not new. In 1947 there was an espoused target to "double our production in the immediate future" (Levy 1948). And again in the early 1960 s a target to increase dairy production by 40 to $50 \%$ was articulated (Smith 1964).

- The need to manage a farm as both a cash flow and capital asset business was identified by Candy in 1934

- The use of fertiliser nitrogen as a means of getting better growth from ryegrass pastures was first proposed by Holford (1934) and mentioned as a passing trend by Harris (1968), Ball (1969), O'Connor \& Gregg (1971), Sherlock \& O'Connor (1973), Ball et al. (1975), Luscombe (1979), Luscombe \& Fletcher (1981), and Thomson \& Roberts (1981). Buxton (1981) noted that use of more than $80 \mathrm{~kg} \mathrm{~N} /$ ha would be uneconomic on dairy farms and suggested its best use was in late autumn to allow more on-farm wintering of cows. Again it was reported that $\mathrm{N}$ use on dairy farms in the Waikato (Bryant et al. 1981) and Taranaki (Thomson et al. 1991) would not be economic; Morris \& McRae (1990) also suggested that $\mathrm{N}$ use in beef production would not be economic. Further reporting indicated that winter $\mathrm{N}$ applications did not give economic returns for early lambing systems (Sheath et al. 1991). However, since the mid-1990s many papers have demonstrated the benefits of $\mathrm{N}$ use. This change has been due more to the increase in returns for dairy (1990 onwards) and for sheep/beef (2000 onwards) than a reduction in the cost of $\mathrm{N}$ and its application. Management decisions to lift annual feed demand (and hence production) above what can traditionally be supplied even from a well fertilised (P, K, S) grass/ clover pasture heavily favours the use of $\mathrm{N}$ as the most cost effective feed source.

- The importance of pasture quality over simply the quantity of dry matter was first mentioned by Riddet (1938)

- Rates of pasture re-sowing have been low for decades. Connell (1938) estimated that at the pasture renewal rates then, it would take 35 to 40 years to resow the farmland being used. Today it is little better with a 30 year timeframe required for re-sowing all farmland. Lancashire (1985) also challenged the industry to enlarge and diversify the demand for New Zealand bred cultivars.

- Quality feed supply was identified as being of equal importance with cow pedigree (Hunger 1951).

- That labour supply limits pastoral agricultural production was indicated by Moore (1953).

- Illegible slide presentations were identified as a 
challenge from the start. Saxby (1954) commented that "a scheme had been devised whereby the bane of all audiences, the illegible slide can be banished forever".

- Debate on the appropriate level of phosphatic fertilisation of productive dairy pasture began in the 1950s (Elliott \& Karlovsky 1954).

- That having reliable and consistent measures of pasture production is a challenge has been a repeated theme (e.g. Lynch 1959; Wallace 1961; Devantier et al. 1998).

- Growing more grass per hectare, that is then efficiently utilised, as a means of continuing to improve animal production was identified by Wallace in 1961.

- In 1968 it was acknowledged that the ability of the New Zealand farmer to remain economically viable in the face of the continuous decline in his terms of trade has been based on technical and management progress (Stewart 1968).

- Adoption of basic management techniques as a requirement for effective pasture establishment was reported by Brougham (1969), Baker (1969), Cullen (1969), and Brock \& Kane (2003).

- Difficulty in translating large differences in herbage production levels (caused by grazing management) into differences in animal production was indicated by Brougham (1970).

- Ceiling pasture yields have challenged agronomists, and yet increases in animal production per unit area were reported by Brougham (1976).

- The use of satellites to measure pasture growth appeared in the 1970s (Cochrane 1976; Ellis 1977)

- The knowledge wave was heralded under the guise of information to continue to improve New Zealand's competitiveness by Trim (1980)

- The development of a large range of models for understanding farm systems and to assist with decision making on-farm began to occur in the 1980s (e.g. McCall et al. 1986; Baars 1990; Marshall et al. 1991; Lewis \& Garrity 1993; Barker \& Baars 1993; Rollo et al. 1996; Metherell et al. 1997; Barioni et al. 1997; Martins da Silva et al. 1997; Wheeler \& Thorrold 1997; Davis et al. 1998; Barker et al. 1998; Ledgard et al. 1999; Woodward et al. 2000; Ogle et al. 2000; Ogle \& Tither 2000; Ridler et al. 2001; Fiorelli et al. 2001; Webby 2002; Wheeler et al. 2003; Thorrold et al. 2004; Monaghan et al. 2004; Zhang et al. 2004; Beukes et al. 2005).

- The potential impact of plant genomic technologies on pastoral agriculture has been discussed since the 1980s (e.g. White 1988; Woodfield \& White 1996;
Scott et al. 1996; Willocks 1999; Barrett et al. 2001; Bryan 2001; Flaville et al. 2003; Barrett et al. 2004).

An interesting commentary on labour productivity was made in the early 1950 s - that "the New Zealand farm worker produces $50 \%$ more than his opposite number in Australia, twice that in Argentina, five times as much as in Britain, and 20 times as much as in Japan" (Moore 1953). Does the same still apply?

At a number of conferences we had speakers from overseas updating us on technologies and information from their pastoral systems, e.g. 1956 (South Africa, UK, USA and the Netherlands), and 1970 (UK, USA and South Africa).

\section{Primary Sector Targets 2015}

Both the dairy (Anon. 2005a), and meat and wool (Anon. 2005b) sectors have identified goals and targets for their industry to be achieved in the next decade.

\section{For the dairy sector the goal is:}

The dairy industry will increase dairy farmer profit and create wealth for the New Zealand economy, through achieving by 2015:

- $50 \%$ total productivity ${ }^{2}$ gain (4\% per year)

- 35\% growth of milksolids (3\% per year)

- Continued 'freedom to operate' through embracing the following imperatives

- growth and productivity goals must not compromise economic, environmental and animal welfare imperatives

\section{For the meat and wool sector the goal is:}

The sheep, beef, and goat industries to increase progressively until 2015 farmer profit and wealth for the New Zealand economy by:

- A 35\% total productivity ${ }^{2}$ gain (3\% per year)

- Successfully addressing industry imperatives and ensuring that society increases its recognition of the meat and fibre sector as a driver of economic national well-being

Each has a specific objective for Feed:

For dairy it is -

1. To profitably increase the metabolisable energy utilised per ha by $50 \%$ from grazed forage

2. To improve pasture feed quality

3. To develop and apply measurements and systems so that supplementary feed is profitably used on dairy farms

For meat and wool it is -

1. To cost effectively and sustainably increase by $35 \%$

\footnotetext{
${ }^{2}$ Productivity is defined as the level of production (output) per unit of effort (input)
} 
the metabolisable energy available from grazed pasture

2. To develop and apply measurements and systems to ensure optimal on-farm use of supplementary feed

The challenge for the research, extension/consultant and farming communities is how to achieve these targets. Can we identify the knowledge and technologies required to achieve either a $50 \%$ or $35 \%$ increase in metabolisable energy available from grazed forage or pasture?

\section{R \& D priorities}

Both the dairy and meat and wool sectors have endorsed Strategic Frameworks to provide direction for future onfarm research, development, extension and education. Both sectors have identified similar priorities for increased R \& D effort based on these Frameworks - they are:

- Supply of high metabolisable energy forage (includes pasture)

- Environmental integrity and sustainability

- Technology integration to deliver improved farm systems

- Improved adoption of current technologies and knowledge

- Biosecurity - pre-border, post-border and traceability

- Labour supply - quality and capacity

What must be done to ensure our pastoral research community is positioned and resourced to deliver these priorities? This question remains to be answered.

\section{New Zealand's R \& D innovation system}

Continued advances in on-farm productivity will rely on both Government and industry supported R \& D. In conjunction with this, to continue to ensure innovation is delivered we need:

- Acknowledged and respected leaders who can inspire a vision for the future of pastoral agriculture in New Zealand, and provide a unified voice into Wellington

- Practitioners who can deliver that vision

- An infrastructure that permits researchers to respond efficiently to farmer issues

- A process for attracting the best and brightest of our young people into pastoral agricultural research and the innovation cycle
- A consolidated and unified approach to solving problems and developing new technologies where industry, R \& D providers and investors are equal partners, and each is respected for their contribution in working towards common and agreed goals

- An enlightened regulatory process that allows facts to overcome emotion and opinion; and common sense to prevail over political agendas

Funding of R \& D has always been an issue. Even back in 1931, Hudson commented that "something like $6 \mathrm{~d}$ to $1 /$ - per $£ 100$ value (i.e. $0.05 \%$ ) of our grassland exports is being spent in grassland research. When the importance of grassland is considered and the small amount compared with what is being spent on research into other primary industries, it is obvious that there is enormous scope for development of grassland research."

Today the R \& D investment is somewhat larger, but over the past 15 years, the Government has reduced the proportion of its on-farm pastoral R \& D investment aimed at 'sustaining and extending competitive and comparative advantage' (FRST 2004). Table 3 shows that dairy farmers contribute significantly to $\mathrm{R} \& \mathrm{D}$ in their sector, with on-farm R \& D funded by industry and industry levy organisations (totalling $1.5 \%$ of sector GDP). This is about three times higher than the average business investment in R \& D for NZ as a whole (estimated at $0.44 \%$ of GDP). Public funding of onfarm R \& D is only $65 \%$ of business-funded R \& D, considerably less than the $1.7: 1$ ratio applying at the aggregate level.

\section{The Future}

The pastoral sectors have been working hard to ensure that decision makers in Wellington understand that pastoral agriculture is New Zealand's knowledge economy and is the major existing and new wealth creator for our economy.

Furthermore the pastoral sectors have set ambitious productivity goals - these are efficiency goals, rather than value propositions. Achieving these goals will mean that we continue to seek ways to produce more output, primarily milk and meat, for less effort or input. Should this really be the way forward? New Zealand's

Table 3 The funding of on-farm and pastoral R\&D relative to comparators

\begin{tabular}{lcc}
\hline R\&D investment & Government & Dairy industry \\
\hline On-farm dairy RD\&E* $^{*}$ & NZD $31 \mathrm{~m}$ & NZD $49 \mathrm{~m}$ \\
- as \% of farmer revenue (i.e. payout) & $0.59 \%$ & $0.92 \%$ \\
- as \% of direct contribution to GDP* & $0.98 \%$ & $1.5 \%$ \\
NZ overall R\&D investment as \% of GDP** & $0.76 \%$ & $0.44 \%$ \\
\hline
\end{tabular}

* 2003/04 ** 2005 Economic Development Indicators Report 
wealth is created from exporting products that others will buy. The New Zealand Institute published a report (2006), "Dancing with the Stars", which states that over the period 1971 to 2002 New Zealand's exports grew $7.8 \%$ in value compared with the world trade growth of $9.5 \%$ a year. This means that our economic well being is declining relative to the rest of the world.

\section{Environment}

As production and productivity increases are sought, continued and improved environmental sustainability will be needed. Pastoral sector leaders are committed to improving the environment and taking a proactive stance, on the basis that:

- It is the 'right' and responsible action to take for the country

- It ensures 'freedom to operate' for the industry

- Resources are finite and must be used effectively and efficiently.

This will also require assistance from the research community and will simply not be a case of isolated technologies but rather a more integrated solution that seeks new systems and ways of managing waste and utilising inputs.

Environmental issues may be the biggest threat to future productivity targets. The $4 \%$ p.a. productivity target is legitimate and needed, but it is not the sole answer. The industry strategies equate these productivity targets to increases in pasture production rather than in the value of each kg of dry matter produced. The proposed increases in pasture production will, without a management change, cause unacceptable environmental damage. Despite some success with the Clean Streams Accord, nutrient management aspects appear to be seriously lagging. At a conference this year, 'Good for Growing ', organised by NZIAHS in Napier, a 10 person representative panel of environmentalists, dairy sector, farmers, MAF policy makers, and fertiliser industry agreed that current farming practices do not meet the needs of current and future generations of New Zealanders. A middle path is going to be very difficult to achieve because, as land values continue their inexorable rise, a viable return is only possible by using more and more unsustainable practices, without a radical change in approach.

\section{Added value}

More added value products have been proposed as the answer to provide adequate returns for on-farm investment for many years. Yet very little changes. Fonterra's shareholders council recently voiced their displeasure with the company's performance in this area. So is it just too hard? Do the strategies of maintaining our competitive international selling position through processing efficiencies simply lead to continued commodity production rather than adding value? Is there a lack of appropriate research and have we completely failed to improve "quality" in pasture feeding and thus raise the value of each $\mathrm{kg}$ of dry matter

On the basis of what has happened over the past 25 years it cannot simply be more of the same. We must find ways to increase the value of what we export. Much of this must be market lead innovation and not simply science and research driven innovation. The issue is that the research community is not receiving clear messages that would inspire them to provide innovative value added products for our major exporting companies. This is unlikely to be resolved until exporters and scientists agree on common goals. However, when resolution is reached, the legacy we have achieved in supporting our pastoral export industries to create value through commodities will continue to play out through increased value added products.

There is much before us to do. Our legacy as grassland researchers, extension specialists and farmers is impressive, but opportunities to improve our performance, and that of the industry, exist. The future of grassland farming will require continued innovation and knowledge creation to remain not just competitive but also capable of creating new wealth.

\section{REFERENCES}

Anon. 2005a. Strategic Framework for New Zealand's Future Dairy Farming and Industry 2005-2015.

Anon. 2005b. Strategic Framework for New Zealand's Future Meat and Fibre Production Research 20052015.

Baars, J.A. 1990. A rational approach to feed planning on farm. Proceedings of the New Zealand Grassland Association 51: 75-78.

Baker, C.J. 1969. The present methods of pasture establishment. Proceedings of the New Zealand Grassland Association 31: 52-59.

Ball, R. 1969. Legume and fertiliser nitrogen in New Zealand pastoral farming. Proceedings of the New Zealand Grassland Association 31: 117-126.

Ball, R.; Inglis, J.A.H.; Mauger, J.H. 1975. Tactical application of fertiliser nitrogen to offset a season feed shortage on a heavily stocked sheep farm in southern Hawke's Bay. Proceedings of the New Zealand Grassland Association 37: 166-181.

Barioni, L.G.; Dake, C.J.; Parker, W.J. 1997. A stochastic model to study the control of grazing systems. Proceedings of the New Zealand Grassland Association 59: 73-78.

Barker, D.J.; Baars, J.A. 1993. Comparing the seasonal productivity of cocksfoot and resident pastures in hill country farms using a system model. Proceedings of the New Zealand Grassland Association 55: 81-85. 
Barker, D.J.; Clark, D.A.; Thom, E. R.; Couchman, J.N.; Burton, R.N.; Dymock, N. 1998. Pasture species and drought impacts on milk yield 2. Predicted farm milk yield at four sites. Proceedings of the New Zealand Grassland Association 60: 45-50.

Barrett, B.A.; Griffiths, A.; Mercer, C.; Ellison, N.; Faville, M.; Easton, S.; Woodfield, D.R. 2001. Markerassisted selection to accelerate forage improvement. Proceedings of the New Zealand Grassland Association 63: 241-245.

Barrett, B.A.; Baird, I.J.; Woodfield, D.R. 2004. Genetic tools for increased white clover seed production. Proceedings of the New Zealand Grassland Association 66: 119-126.

Beukes, P.C.; Palliser, C.C.; Prewer, W.E.; Levy, G.; Folkers, C.; Meal, M.; Wastney, M.E.; Thorrold, B.S. 2005. Comparing risk for different dairy farm management systems in Taranaki using the Dexcel Whole Farm Model. Proceedings of the New Zealand Grassland Association 67: 103-107.

Bray, A. 2004. More lamb from less. Journal of Primary Industry Management 7: 32-33.

Brock, J.L.; Kane, G.J. 2003. Variability in establishing white clover in pastures on farm. Proceedings of the New Zealand Grassland Association 65: 223-228.

Brougham, R.W. 1969. Present position of pasture establishment research in New Zealand. Proceedings of the New Zealand Grassland Association 31: 4351.

Brougham, R.W. 1970. Frequency and intensity of grazing and their effects on pasture. Proceedings of the New Zealand Grassland Association 32: 137-144.

Brougham, R.W. 1976. Some aspects of pasture development and management in New Zealand. Proceedings of the New Zealand Grassland Association 38: 38-46.

Bryan, G.T. 2001. Biotechnology in forage crops capturing our potential. Proceedings of the New Zealand Grassland Association 63: 235-239.

Bryant, A.M.; MacDonald, K.A.; Clayton, D.G. 1981. Effects of nitrogen fertiliser on production of milk solids from grazed pasture. Proceedings of the New Zealand Grassland Association 43: 58-63.

Buxton, D.A.L. 1981. Economics of nitrogen use in dairying. Proceedings of the New Zealand Grassland Association 43: 70-75.

Callaghan, F.R. 1935. The probable utilisation of New Zealand grassland. Proceedings of the New Zealand Grassland Association 4: 78-83.

Candy, R.A. 1934. The economic use of pastures in dairying. Proceedings of the New Zealand Grassland Association 3: Paper 18.

Caradus, J. R. 2005. Productivity - What is it? Pp 110112 In: Proceedings of 2nd International Large Herds
Conference - Dairying towards 2020..

Cochrane, G.R. 1976. Remote sensing applications in pasture analysis. Proceedings of the New Zealand Grassland Association 38: 226-245.

Connell, R.P. 1933. Some aspects of problems relative to increased application of knowledge of grassland farming. Proceedings of the New Zealand Grassland Association 2: Paper 9.

Connell, R.P. 1938. Some features of current land use. Proceedings of the New Zealand Grassland Association 7: Paper 5.

Cullen, N.A. 1969. Oversowing grasses and clovers. Proceedings of the New Zealand Grassland Association 31: 110-116.

Davis, K.L.; Thomson, N.A.; McLean, N.R.; McCallum, D.A.; Hainsworth, R.J.; Wards, A.J.; Barton, R.G. 1998. Pasture growth on dairy farms in the Golden Bay and West Coast of the South Island. Proceedings of the New Zealand Grassland Association 60: 9-4.

Devantier, B.P.; Lambert, M.G.; Brookes, I.M.; Hawkins, C.L. 1998. Measuring production of continuously grazed hill pasture. Proceedings of the New Zealand Grassland Association 60: 157-160.

Elliott, I.L.; Karlovsky, J. 1954. The use of phosphates on some major Waikato soil types. Proceedings of the New Zealand Grassland Association 16: 176-185.

Ellis, P.J. 1977. Remote sensing data from spacecraft and aircraft: their processing and application. Proceedings of the New Zealand Grassland Association 39: 174-189.

Fiorelli, C.F.; Woodward, S.J.R.; Wasteny, M.E.; Thom, E.R.; Bahmani, I. 2001. Modelling factors affecting reproductive development of perennial ryegrass in Waikato dairy pastures. Proceedings of the New Zealand Grassland Association 63: 165-170.

Flaville, M.; Barrett, B.; Griffiths, A.; Schreiber, M.; Mercer, C.; Baird, I.; Ellison, N.; Bryan, G.; Woodfield, D.; Forster, J.; Ong, B.; Sawbridge, T.; Spangenberg, G.; Easton, H.S. 2003. Implementing molecular marker technology in forage improvement. Proceedings of the New Zealand Grassland Association 65: 229238.

FRST 2004. Investing in Our Future, Progress and Achievements Report, FRST, 2004, Table 2.2, p.23.

Garland, C. 1993. Technology transfer: systems used by a Wairarapa farm consultancy firm. Proceedings of the New Zealand Grassland Association 55: 7-9.

Hall, J.; Scobie, G.M. 2006. The role of R \& D in productivity growth: the case of agriculture in New Zealand: 1927 to 2001. New Zealand Treasury Working Paper 06/01.

Hamblyn, C.J. 1947. A critical review of present day trends in grasslands farming. Proceedings of the New Zealand Grassland Association 9: 28-30. 
Harris, W. 1968. Pasture seeds mixtures, competition and productivity. Proceedings of the New Zealand Grassland Association 30: 143-153.

Holford, G.H. 1934. Five years' experience in the use of nitrogen on pastures in New Zealand. Proceedings of the New Zealand Grassland Association 3: Paper 22.

Hudson, A.W. 1931. The use of fertilizers on grassland and the technique and scope of experimental work. Proceedings of the New Zealand Grassland Association 1: 21-23.

Hunger, W.C. 1951. Higher production on dairy farms. Proceedings of the New Zealand Grassland Association 13: 98 - 100.

Lancashire, J.A. 1985. Some factors affecting the rate of adoption of new herbage cultivars. Using Herbage Cultivars. Grassland Research and Practice Series 3: 79-87.

Ledgard, S.F.; Edgecombe, G.A.; Roberts, A.H.C. 1999. Application of the nutrient budgeting model OVERSEER ${ }^{\mathrm{TM}}$ to assess management options and regional council consent requirements on a Hawke's Bay dairy farm. Proceedings of the New Zealand Grassland Association 61: 227-231.

Levy, E.B. 1948. Developments in grassland farming. Proceedings of the New Zealand Grassland Association 10: 35-44.

Lewis, C.A.; Garrity, B. 1993. Application of a computer dairy model on farm. Proceedings of the New Zealand Grassland Association 55: 217-218.

Luscombe, P.C. 1979. Nitrogen fertilizer responses on hill country pastures. Proceedings of the New Zealand Grassland Association 41: 155-162.

Luscombe, P.C.; Fletcher, R.H. 1981. Nitrogen fertiliser on grazed hill pasture. Proceedings of the New Zealand Grassland Association 43: 171-181.

Lynch, P.B. 1959. Pasture production estimates by measures other than cutting. Proceedings of the New Zealand Grassland Association 21: 99-107.

MacClean, J.; Penno, J.; Howse, S. 1997. Current information and technology priorities of dairy farmers. A challenge for agricultural researchers. Proceedings of the New Zealand Grassland Association 59: 215220.

Manson, P. 1999. The McRae Trust sustainable land management project: A community based approach to sustainable hill country farming. Proceedings of the New Zealand Grassland Association 61: 185-188.

Marshall, P.R.; McCall, D.G.; Johns, K.L. 1991. STOCKPOL: A decision support model for livestock farms. Proceedings of the New Zealand Grassland Association 53: 137-140.

Martins da Silva, J.A.; Parker, W.J.; Shadbolt, N.M.; Dake, C.K. 1997. Pasture development revisited: A model to analyse the physical and financial risk of developing pastures on sheep and beef cattle farms. Proceedings of the New Zealand Grassland Association 59: 67-72.

McCall, D.G.; Townsley, R.J.; Bircham, J.S.; Sheath, G.W. 1986. The interdependence of animal intake, preand post-grazing pasture mass ad stocking density. Proceedings of the New Zealand Grassland Association 47: 255-261.

McKenzie, S.A. 1980. The changing pattern of advisory work. Proceedings of the New Zealand Grassland Association 42: 191-193.

McRae, A.F. 1992. Farmers' needs for management, research and extension, and policy - findings of a farmers' workshop and their implications. Proceedings of the New Zealand Grassland Association 54: 7-10.

Metherell, A.K.; Thorrold, B.S.; Woodward, S.J.R.; McCall, D.G.; Marshall, J.D.; Morton, J.D.; Johns, K.L. 1997. A decision support model for fertiliser recommendations for grazed pasture. Proceedings of the New Zealand Grassland Association 59: 137-140.

Monaghan, R.M.; Smeaton, D.; Hyslop, M.G.; Stevens, D.R.; de Klein, C.A.M.; Smith, L.C.; Drewry, J.J.; Thorrold, B.S. 2004. A desktop evaluation of the environmental and economic performance of model dairy farming systems within four New Zealand catchments. Proceedings of the New Zealand Grassland Association 66: 57-67.

Moore, A.B. 1953. Increasing production from Northland hill country. Proceedings of the New Zealand Grassland Association 15: 68-78.

Morris, S.T.; McRae, A.F. 1990. Evaluation of nitrogen fertiliser in a beef production system. Proceedings of the New Zealand Grassland Association 51: 89-92.

O'Connor, M.B.; Gregg, P.E.H. 1971. Nitrogen fertilizer trials on pastures. Proceedings of the New Zealand Grassland Association 33: 26-34.

Ogle, G.I.; Tither, P. 2000. An analysis of the risks and benefits of beef intensification. Proceedings of the New Zealand Grassland Association 62: 25-29.

Ogle, G.I.; Allan, B.E.; Campbell, A.; Bates, J.R. 2000. Financial analysis of pasture improvement on Earnscleugh Station. Proceedings of the New Zealand Grassland Association 62: 167-172.

Prewer, W.E.; van Bysterveldt, A. 2004. The Pasture Quality Poster - a learning tool for farmers. Proceedings of the New Zealand Grassland Association 66: 183-186.

Riddet, W. 1938. The relation of pasture species to quantity and quality of milk. Proceedings of the New Zealand Grassland Association 7: Paper 11.

Ridler, B.J.; Rendel, J.M.; Baker, A. 2001. Driving innovation: Application of linear programming to improving farm systems. Proceedings of the New Zealand Grassland Association 63: 295-298. 
Robertson, B.T. 1980. The effective publication of grassland research. Proceedings of the New Zealand Grassland Association 42: 194-200.

Rollo, M.D.; McCall, D.G.; Boom, C.J.; Sheath, G.W. 1996. Evaluation of a beef growth model for use in beef finishing decisions. Proceedings of the New Zealand Grassland Association 57: 95-99.

Savage, J.; Lewis, C. 2005. Applying science as a tool for dairy farmers. Proceedings of the New Zealand Grassland Association 67: 61-66.

Saxby, S.H. 1954. The New Zealand Grassland Association. Proceedings of the New Zealand Grassland Association 16: 24 - 34 .

Scott, A.; Woodfield, D.R.; Allan, A.; Maher, D.; White D.W.R. 1996. Inheritance and expression of transgenes in white clover. White Clover: New Zealand's Competitive Edge. Agronomy Society of New Zealand Special Publication 11/ Grassland Research and Practice Series 6: 131-135.

Sheath, G.W.; Boom, C.J.; Webby, R.W. 1991. Nitrogen fertiliser use in early lambing systems. Proceedings of the New Zealand Grassland Association 53: 123-128.

Sherlock, R.R.; O'Connor, M.B. 1973. The use of nitrogen on hill country. Proceedings of the New Zealand Grassland Association 35: 52-62.

Smith, B.A.J. 1964. Pasture management for high production on dairy farms. Proceedings of the New Zealand Grassland Association 26: 129-136.

Stewart, J.D. 1968. Profitability and economics of cropping. Proceedings of the New Zealand Grassland Association 30: 72-80.

Thomson, N.A.; Roberts, A.H.C. 1981. Response to nitrogen fertiliser applied to dairy pastures in autumn and spring in Taranaki. Proceedings of the New Zealand Grassland Association 43: 44-52.

Thomson, N.A.; Roberts, A.H.C.; Judd, T.G.; Clough, J.S. 1991. Maximising dairy production by using nitrogen fertiliser and calving early. Proceedings of the New Zealand Grassland Association 53: 85-90.

Thorrold, B.S.; Bright, K.P.; Palmer, C.A.; Wastney, M.E. 2004. Modelling the effects of irrigation reliability on pasture growth in a dairy system in Canterbury. Proceedings of the New Zealand Grassland Association 66: 31-34.

Trim, P.N. 1980. Agricultural information: New Zealand's forgotten fuel. Proceedings of the New
Zealand Grassland Association 42: 201-204.

van der Geest, C. 2002. Sources and uses of information on a West Coast dairy farm. Proceedings of the New Zealand Grassland Association 64: 31-32.

Wallace, L.R. 1961. Modern trends in grassland farming. Proceedings of the New Zealand Grassland Association 23: 75-84.

Webby, R.W. 2002. The value of decision support models for farmer learning. Proceedings of the New Zealand Grassland Association 64: 45-47.

Webby, R.W.; Sheath, G.W. 1991. Group monitoring, a basis for decision making and technology transfer on sheep and beef farms. Proceedings of the New Zealand Grassland Association 53: 13-16.

Wheeler, D.M.; Thorrold, B.S. 1997. Pasture yield response to different sulphur fertiliser strategies and its application to modelling. Proceedings of the New Zealand Grassland Association 59: 39-43.

Wheeler, D.M.; Ledgard, S.F.; de Klein, C.A.M.; Monaghan, R.M.; Carey, P.L.; McDowell, R.W.; Johns, K.L. 2003. OVERSEER ${ }^{\circledR}$ nutrient budgets moving towards on-farm resource accounting. Proceedings of the New Zealand Grassland Association 65: 191-194.

White, D.W.R. 1988. Use of cell and molecular genetic manipulation to improve pasture plants. Proceedings of the New Zealand Grassland Association 49: 6772.

Willocks, M.J. 1999. Commercialisation of genetically modified crops in New Zealand. Proceedings of the New Zealand Grassland Association 61: 117-119.

Woodfield, D.R.; White, D.W.R. 1996. Breeding strategies for developing transgenic white clover cultivars. White Clover: New Zealand's Competitive Edge. Agronomy Society of New Zealand Special Publication 11/ Grassland Research and Practice Series 6: 125-130.

Woodward, S.J.R.; Webby, R.W.; Johnstone, L.J.C. 2000. A decision tool for calculating herbage mass and metabolisable energy requirements of growing cattle and sheep. Proceedings of the New Zealand Grassland Association 62: 13-18.

Zhang, B.S.; Valentine, I.; Kemp, P.D. 2004. Modelling hill country pasture production: a decision tree approach. Proceedings of the New Zealand Grassland Association 66: 195-201. 
APPENDIX 1

\section{Technological advances impacting on grassland farming}

\begin{tabular}{|c|c|c|}
\hline Technology/advance & Impact/significance & Date - NZGA Proceedings \\
\hline $\begin{array}{l}\text { Strain development in } \\
\text { herbage plants }\end{array}$ & Elite cultivars & Levy 1931 - NZGA Vol. 1 \\
\hline $\begin{array}{l}\text { Economic value of } \\
\text { phosphatic fertilisers }\end{array}$ & $\begin{array}{l}\text { Improved productivity and } \\
\text { production }\end{array}$ & Hudson 1931 - NZGA Vol. 1 \\
\hline $\begin{array}{l}\text { Grazing management } \\
\text { systems - rotational grazing } \\
\text { for dairy farms }\end{array}$ & $\begin{array}{l}\text { Better utilisation of grown } \\
\text { pasture }\end{array}$ & Connell 1931 - NZGA Vol. 1 \\
\hline Seed certification & Quality seeds assurance & Hadfield 1933 - NZGA Vol. 2 \\
\hline Use of irrigation & $\begin{array}{l}\text { Increase the area of } \\
\text { economically viable agricultural } \\
\text { land }\end{array}$ & Tennent 1933 - NZGA Vol. 2 \\
\hline $\begin{array}{l}\text { Using social sciences to } \\
\text { improve uptake and adoption } \\
\text { of new knowledge }\end{array}$ & $\begin{array}{l}\text { Use of best knowledge and } \\
\text { technologies by farmers }\end{array}$ & Connell 1933 - NZGA Vol. 2 \\
\hline $\begin{array}{l}\text { Improved grazing } \\
\text { management of hill country }\end{array}$ & $\begin{array}{l}\text { Reduce reversion back to weeds } \\
\text { and scrub - maintain or improve } \\
\text { productivity }\end{array}$ & McCulloch 1933 - NZGA Vol. 2 \\
\hline $\begin{array}{l}\text { Importance of trace elements } \\
\text { in animal nutrition }\end{array}$ & Stopped "bush sickness" & $\begin{array}{l}\text { Riggs \& Askew } 1933 \text { - NZGA } \\
\text { Vol. } 2\end{array}$ \\
\hline Concept of grass as a crop & Better utilisation of pasture & Callaghan 1933 - NZGA Vol. 2 \\
\hline $\begin{array}{l}\text { Aligning production to } \\
\text { market needs, including the } \\
\text { need for diversification }\end{array}$ & Improved profitability & Williams 1933 - NZGA Vol. 2 \\
\hline $\begin{array}{l}\text { Use of heterosis in forage } \\
\text { plant breeding }\end{array}$ & Improved pasture production & Frankel 1934 - NZGA Vol. 3 \\
\hline Soil surveys & $\begin{array}{l}\text { Understanding soil impacts on } \\
\text { pasture production }\end{array}$ & $\begin{array}{l}\text { Grand \& Taylor } 1934 \text { - NZGA } \\
\text { Vol. } 3\end{array}$ \\
\hline $\begin{array}{l}\text { Interaction between pasture } \\
\text { nutritional value and animal } \\
\text { metabolism }\end{array}$ & $\begin{array}{l}\text { Realisation that not all pasture } \\
\text { feed is equal }\end{array}$ & Franklin 1934 - NZGA Vol. 3 \\
\hline $\begin{array}{l}\text { Differing palatability of } \\
\text { pasture species }\end{array}$ & $\begin{array}{l}\text { Animals have different } \\
\text { preferences for different pasture } \\
\text { types }\end{array}$ & $\begin{array}{l}\text { Cunningham } 1934 \text { - NZGA Vol. } \\
3\end{array}$ \\
\hline $\begin{array}{l}\text { Adapting farm business to } \\
\text { economic adversity }\end{array}$ & $\begin{array}{l}\text { Balancing farming as a cash } \\
\text { flow business and land asset } \\
\text { business }\end{array}$ & Candy 1934 - NZGA Vol. 3 \\
\hline $\begin{array}{l}\text { Impact of stocking rate on } \\
\text { pasture composition and } \\
\text { production }\end{array}$ & Improved productivity & Levy 1934 - NZGA Vol. 3 \\
\hline $\begin{array}{l}\text { Use of } \mathrm{N} \text { fertiliser to improve } \\
\text { pasture production }\end{array}$ & Improved productivity & Holford 1934 - NZGA Vol. 3 \\
\hline Use of lime & $\begin{array}{l}\text { Improved pasture production and } \\
\text { seasonality of production }\end{array}$ & Woodcock 1935 - NZGA Vol. 4 \\
\hline Supplementary feed crops & $\begin{array}{l}\text { Aid to pasture improvement and } \\
\text { management }\end{array}$ & Connell 1935 - NZGA Vol. 4 \\
\hline $\begin{array}{l}\text { Need for better extension } \\
\text { methods for adopting } \\
\text { knowledge }\end{array}$ & Improved productivity & Callaghan 1935 - NZGA Vol. 4 \\
\hline Use of fluorescents and & Uniform seed lines & Foy \& Hyde 1935 - NZGA Vol. \\
\hline
\end{tabular}




\begin{tabular}{|c|c|c|}
\hline Technology/advance & Impact/significance & Date - NZGA Proceedings \\
\hline $\begin{array}{l}\text { cyanogenesis to identify } \\
\text { germplasm types }\end{array}$ & & 4 \\
\hline $\begin{array}{l}\text { Lucerne breeding for NZ } \\
\text { begins }\end{array}$ & Lucerne cultivars & Calder 1935 - NZGA Vol. 4 \\
\hline $\begin{array}{l}\text { White and red clover cause } \\
\text { feed flavour effects in milk }\end{array}$ & $\begin{array}{l}\text { Understanding of impact of feed } \\
\text { on milk flavour and probably } \\
\text { composition }\end{array}$ & $\begin{array}{l}\text { Riddet et al. } 1936 \text { - NZGA Vol. } \\
5\end{array}$ \\
\hline $\begin{array}{l}\text { Indication of mineral } \\
\text { deficiencies in NZ pasture on } \\
\text { animal health and production }\end{array}$ & Importance of $\mathrm{Co}, \mathrm{I}$, and $\mathrm{Fe}$ & Hopkirk 1936 - NZGA Vol. 5 \\
\hline $\begin{array}{l}\text { Investigation of paspalum as } \\
\text { a forage }\end{array}$ & $\begin{array}{l}\text { Impact of } \mathrm{C}_{4} \text { grasses in } \mathrm{NZ} \\
\text { pasture }\end{array}$ & Hamblyn 1936 - NZGA Vol. 5 \\
\hline $\begin{array}{l}\text { Investigation of the use of } \\
\text { subterranean clover cultivars } \\
\text { in pasture }\end{array}$ & $\begin{array}{l}\text { Impact of annual clovers in NZ } \\
\text { pastures }\end{array}$ & $\begin{array}{l}\text { Levy \& Gorman } 1936 \text { - NZGA } \\
\text { Vol. } 5\end{array}$ \\
\hline $\begin{array}{l}\text { Identification of excessive } \\
\text { protein levels in NZ pastures }\end{array}$ & Impact on animal fertility & Webster 1936 - NZGA Vol. 5 \\
\hline $\begin{array}{l}\text { Lack of demonstration and } \\
\text { research stations in the South } \\
\text { Island }\end{array}$ & $\begin{array}{l}\text { Missed opportunities to adopt } \\
\text { advances in the South Island }\end{array}$ & Macassey 1936 - NZGA Vol. 5 \\
\hline $\begin{array}{l}\text { Acknowledgement of seed } \\
\text { mixture differences for wet } \\
\text { and dry areas of NZ }\end{array}$ & $\begin{array}{l}\text { Seed mixtures tailored to need } \\
\text { and climate }\end{array}$ & $\begin{array}{l}\text { Stuart 1937; } \\
\text { Flay } 1937 \text { - NZGA Vol. } 6\end{array}$ \\
\hline $\begin{array}{l}\text { Seed sold to legislated } \\
\text { standard in Australia, but not } \\
\text { NZ }\end{array}$ & Free market alive in $\mathrm{NZ}$ & Foy 1937 - NZGA Vol. 6 \\
\hline $\begin{array}{l}\text { Irrigation expands in the } \\
\text { South Island }\end{array}$ & $\begin{array}{l}\text { Improved production and } \\
\text { productivity }\end{array}$ & Stafford 1937 - NZGA Vol. 6 \\
\hline $\begin{array}{l}\text { Link of root health and } \\
\text { vigour to leaf growth in } \\
\text { pasture }\end{array}$ & $\begin{array}{l}\text { Acknowledgment of importance } \\
\text { of root systems }\end{array}$ & Jacques 1937 - NZGA Vol. 6 \\
\hline $\begin{array}{l}\text { Link between condition of } \\
\text { grassland and internal } \\
\text { parasite prevalence }\end{array}$ & $\begin{array}{l}\text { Management of internal } \\
\text { parasites through management of } \\
\text { pastures }\end{array}$ & Cole 1937 - NZGA Vol. 6 \\
\hline $\begin{array}{l}\text { I deficiency in domesticated } \\
\text { animals grazing on alluvial } \\
\text { soils }\end{array}$ & Need for supplementation & Day-us 1937 - NZGA Vol. 6 \\
\hline $\begin{array}{l}\text { Critical analysis of phosphate } \\
\text { fertiliser use and place of } \\
\text { rock phosphate }\end{array}$ & $\begin{array}{l}\text { Understand the long term } \\
\text { impacts of phosphate } \\
\text { fertilisation and technologies for } \\
\text { using rock phosphate }\end{array}$ & $\begin{array}{l}\text { Hudson \& Woodcock } 1937 \text { - } \\
\text { NZGA Vol. } 6\end{array}$ \\
\hline $\begin{array}{l}\text { Impact of shelter trees on } \\
\text { farm production }\end{array}$ & $\begin{array}{l}\text { Concerns about shelter belt } \\
\text { removal, particularly on the } \\
\text { South Island. Recognition of } \\
\text { importance of on-farm shelter } \\
\text { for animal production }\end{array}$ & Dolamore 1937 - NZGA Vol. 6 \\
\hline $\begin{array}{l}\text { Understanding the link } \\
\text { between forest removal and } \\
\text { increased erosion }\end{array}$ & $\begin{array}{l}\text { Impact of replacing forest with } \\
\text { grassland on soil erosion }\end{array}$ & Taylor 1938 - NZGA Vol. 7 \\
\hline $\begin{array}{l}\text { The importance of feed value } \\
\text { rather than feed amount }\end{array}$ & $\begin{array}{l}\text { Impact of feed quality on animal } \\
\text { product quality and composition }\end{array}$ & Riddet 1938 - NZGA Vol. 7 \\
\hline $\begin{array}{l}\text { Pasture re-sowing rates are } \\
\text { too low }\end{array}$ & $\begin{array}{l}\text { At rates used it would take } 35 \text { to } \\
40 \text { years to re-sow the farmland }\end{array}$ & Connell 1938 - NZGA Vol. 7 \\
\hline
\end{tabular}




\begin{tabular}{|c|c|c|}
\hline Technology/advance & Impact/significance & Date - NZGA Proceedings \\
\hline & being used & \\
\hline $\begin{array}{l}\text { Seed certification and purity } \\
\text { assurance schemes }\end{array}$ & $\begin{array}{l}\text { Farmers are assured of getting a } \\
\text { quality seed product }\end{array}$ & Gorman 1947 - NZGA Vol. 9 \\
\hline $\begin{array}{l}\text { Pasture management affects } \\
\text { on sward composition }\end{array}$ & $\begin{array}{l}\text { Importance of managing } \\
\text { pastures to keep white clover } \\
\text { content high }\end{array}$ & Long 1947 - NZGA Vol. 9 \\
\hline $\begin{array}{l}\text { Importance of mechanisation } \\
\text { to increase on-farm } \\
\text { productivity, e.g. replacing } \\
\text { horses with tractors, aerial } \\
\text { topdressing }\end{array}$ & $\begin{array}{l}\text { Improved on-farm productivity- } \\
\text { more output per effort of input }\end{array}$ & Saxby 1947 - NZGA Vol. 9 \\
\hline $\begin{array}{l}\text { Replacing set stocking with } \\
\text { mob grazing on hill country }\end{array}$ & $\begin{array}{l}\text { Improved sward composition } \\
\text { and production }\end{array}$ & Linklater 1947 - NZGA Vol. 9 \\
\hline $\begin{array}{l}\text { Importance of effective } \\
\text { technology transfer }\end{array}$ & $\begin{array}{l}\text { Realisation that uptake of } \\
\text { current knowledge on pasture } \\
\text { development and utilisation by } \\
\text { farmers is slow }\end{array}$ & Hamblyn 1947 - NZGA Vol. 9 \\
\hline Subdivision & $\begin{array}{l}\text { Improved control of stock } \\
\text { grazing pasture to improve } \\
\text { pasture yield and utilisation }\end{array}$ & Levy 1948 - NZGA Vol. 10 \\
\hline $\begin{array}{l}\text { Development of short } \\
\text { rotation }(\mathrm{H} 1) \text { ryegrass }\end{array}$ & $\begin{array}{l}\text { Increased palatability, } \\
\text { production and early spring } \\
\text { growth }\end{array}$ & Corkill 1949 - NZGA Vol. 11 \\
\hline Use of lucerne grass mixtures & $\begin{array}{l}\text { Improved seasonality of } \\
\text { production on 'light' land }\end{array}$ & Bevan 1949 - NZGA Vol. 11 \\
\hline $\begin{array}{l}\text { Survival of hard white clover } \\
\text { seed through the rumen }\end{array}$ & $\begin{array}{l}\text { Opportunity to use the animal to } \\
\text { disseminate clover around the } \\
\text { farm }\end{array}$ & Suckling 1950 - NZGA Vol. 12 \\
\hline $\begin{array}{l}\text { Use of electric fencing to } \\
\text { vary paddock size and } \\
\text { improve pasture utilisation - } \\
\text { "break grazing" }\end{array}$ & Better pasture utilisation & Allo 1951 - NZGA Vol. 13 \\
\hline $\begin{array}{l}\text { Special purpose pastures and } \\
\text { seasonal spread of production }\end{array}$ & $\begin{array}{l}\text { Improved seasonal spread of } \\
\text { feed }\end{array}$ & $\begin{array}{l}\text { Smallfield } 1951 \text { - NZGA Vol. } \\
13\end{array}$ \\
\hline $\begin{array}{l}\text { A well bred cow is only half } \\
\text { the story - pasturage must } \\
\text { equal pedigree }\end{array}$ & $\begin{array}{l}\text { Quality feed supply is as } \\
\text { important as cow pedigree }\end{array}$ & Hunger 1951 - NZGA Vol. 13 \\
\hline $\begin{array}{l}\text { The importance of draining } \\
\text { land }\end{array}$ & Improved production & Hudson 1951 - NZGA Vol. 13 \\
\hline $\begin{array}{l}\text { Integration of forage crops } \\
\text { into pastoral agriculture }\end{array}$ & $\begin{array}{l}\text { Improved winter and summer } \\
\text { feed and process for re-sowing } \\
\text { pasture }\end{array}$ & Bevin 1951 - NZGA Vol. 13 \\
\hline $\begin{array}{l}\text { Earthworms appear } \\
\text { beneficial to pasture growth }\end{array}$ & Improved ryegrass production & Water 1951 - NZGA Vol. 13 \\
\hline $\begin{array}{l}\text { The need for Mo as a trace } \\
\text { element in fertiliser }\end{array}$ & $\begin{array}{l}\text { Improved N-fixation and fodder } \\
\text { crop growth }\end{array}$ & $\begin{array}{l}\text { Davies } 1952 \text { - NZGA Vol. } 14 \\
\text { Adams } 1952 \text { - NZGA Vol. } 14\end{array}$ \\
\hline $\begin{array}{l}\text { Understanding of the role of } \\
\text { statistics in pasture trials }\end{array}$ & Reliable results and analysis & Glenday 1952 - NZGA Vol. 14 \\
\hline $\begin{array}{l}\text { Development of the roller } \\
\text { drill }\end{array}$ & $\begin{array}{l}\text { Better contact between seed and } \\
\text { fertiliser at a constant sowing } \\
\text { depth }\end{array}$ & $\begin{array}{l}\text { Blackmore } 1952 \text { - NZGA Vol. } \\
14\end{array}$ \\
\hline $\begin{array}{l}\text { Need to attract people back } \\
\text { to farming }\end{array}$ & $\begin{array}{l}\text { Labour limiting pastoral farming } \\
\text { productivity }\end{array}$ & Moore 1953 - NZGA Vol. 15 \\
\hline
\end{tabular}




\begin{tabular}{|c|c|c|}
\hline Technology/advance & Impact/significance & Date - NZGA Proceedings \\
\hline $\begin{array}{l}\text { Methods for managing } \mathrm{C}_{4} \\
\text { grasses in northern NZ }\end{array}$ & $\begin{array}{l}\text { Improved seasonal pasture } \\
\text { production }\end{array}$ & Ballinger 1953 - NZGA Vol. 15 \\
\hline $\begin{array}{l}\text { Mechanisation for draining } \\
\text { land }\end{array}$ & Improved productivity & Scott 1953 - NZGA Vol. 15 \\
\hline $19 \mathrm{t} \mathrm{DM} /$ ha produced & $\begin{array}{l}\text { Upper limit of pasture } \\
\text { production measured in NZ - at } \\
\text { Dargaville Demonstration Farm }\end{array}$ & Lynch 1953 - NZGA Vol. 15 \\
\hline Surface drains & $\begin{array}{l}\text { Used to drain land not suitable } \\
\text { for underground drains, e.g. } \\
\text { Hauraki Plains }\end{array}$ & Banfield 1953 - NZGA Vol. 15 \\
\hline $\begin{array}{l}\text { Identification of temperature } \\
\text { optima for our major pasture } \\
\text { species }\end{array}$ & $\begin{array}{l}\text { Better understanding of } \\
\text { temperature limitations to } \\
\text { pasture growth }\end{array}$ & Mitchell 1954 - NZGA Vol. 16 \\
\hline Soil and water conservation & $\begin{array}{l}\text { Realisation of the importance of } \\
\text { protecting natural resources that } \\
\text { drive agricultural production }\end{array}$ & Wilkie 1954 - NZGA Vol. 16 \\
\hline $\begin{array}{l}\text { Importance of maintaining } \\
\text { soil phosphorus levels - } \\
\text { heavy reliance of NZ pastoral } \\
\text { agriculture on fertiliser inputs }\end{array}$ & $\begin{array}{l}\text { The need for discrimination to } \\
\text { be exercised when } \\
\text { recommending fertiliser inputs, } \\
\text { but in general NZ soils need } \\
\text { increased levels of } \mathrm{P} \text { and } \mathrm{K} \text { and } \\
\text { possibly N inputs }\end{array}$ & $\begin{array}{l}\text { Elliott \& Karlovsky } 1954 \text { - } \\
\text { NZGA Vol. } 16\end{array}$ \\
\hline $\begin{array}{l}\text { Use of selective chemical } \\
\text { herbicides to manage pasture } \\
\text { weed }\end{array}$ & $\begin{array}{l}\text { Improved sward composition } \\
\text { and production }\end{array}$ & Matthews 1954 - NZGA Vol. 16 \\
\hline Pasture spelling & $\begin{array}{l}\text { Increased stocking rate and } \\
\text { production }\end{array}$ & Hamblyn 1954 - NZGA Vol. 16 \\
\hline $\begin{array}{l}\text { Bloat caused by foam from } \\
\text { natural fermentation of feed } \\
\text { in the rumen - use of anti- } \\
\text { foaming agents }\end{array}$ & $\begin{array}{l}\text { Management of bloat using } \\
\text { emulsifiers }\end{array}$ & Reid 1955 - NZGA Vol. 17 \\
\hline $\begin{array}{l}\text { Ovine rickets in winter due to } \\
\text { green feed (cereals) diet }\end{array}$ & $\begin{array}{l}\text { Mitigated using an appropriate } \\
\text { drench }\end{array}$ & Grant 1955 - NZGA Vol. 17 \\
\hline $\begin{array}{l}\text { Soils deficient in cobalt } \\
\text { characterised; use of vitamin } \\
\mathrm{B}_{12} \text { testing to determine } \mathrm{Co} \\
\text { deficiency in sheep }\end{array}$ & $\begin{array}{l}\text { Appropriate management of } \\
\text { soils and reduction in severity } \\
\text { and incidence of Co deficiency } \\
\text { in sheep }\end{array}$ & Andrews 1955 - NZGA Vol. 17 \\
\hline Over drilling of pastures & Sward rejuvenation & $\begin{array}{l}\text { Blackmore } 1955 \text { - NZGA Vol. } \\
17\end{array}$ \\
\hline $\begin{array}{l}\text { Use of effective rhizobium } \\
\text { strains to nodulate clovers }\end{array}$ & $\begin{array}{l}\text { Improved white clover survival, } \\
\text { growth and N-fixation }\end{array}$ & $\begin{array}{l}\text { Sears \& Greenwood } 1955 \text { - } \\
\text { NZGA Vol. } 17\end{array}$ \\
\hline $\begin{array}{l}\text { Trace element deficiencies } \\
\text { limited to defined soil types - } \\
\text { deficiencies of major } \\
\text { elements are more } \\
\text { widespread for } \mathrm{P}, \mathrm{K} \text { and } \mathrm{S}\end{array}$ & $\begin{array}{l}\text { Appropriate use of trace and } \\
\text { major elements as fertilisers }\end{array}$ & During 1955 - NZGA Vol. 17 \\
\hline $\begin{array}{l}\text { Link between grazing } \\
\text { behaviour and production }\end{array}$ & $\begin{array}{l}\text { Individuality of cows in relation } \\
\text { to selectivity of diet from pasture }\end{array}$ & Brumby 1955 - NZGA Vol. 17 \\
\hline Nutrition related disorders & $\begin{array}{l}\text { Understanding causes for hypo- } \\
\text { magnesaemia }\end{array}$ & Allcroft 1956 - NZGA Vol. 18 \\
\hline $\begin{array}{l}\text { Economics of irrigation of } \\
\text { "light land" in Canterbury }\end{array}$ & $\begin{array}{l}\text { Improved production and } \\
\text { profitability, but at a cost - } \\
\text { irrigation schemes are expensive }\end{array}$ & $\begin{array}{l}\text { Scott \& Stuart 1956; Hilgendorf } \\
1956 \text { - NZGA Vol. } 18\end{array}$ \\
\hline
\end{tabular}




\begin{tabular}{|c|c|c|}
\hline Technology/advance & Impact/significance & Date - NZGA Proceedings \\
\hline & to implement & \\
\hline $\begin{array}{l}\text { Deterioration of quality and } \\
\text { quantity in NZ tussock } \\
\text { grasslands }\end{array}$ & Loss of production & Hercus 1956 - NZGA Vol. 18 \\
\hline $\begin{array}{l}\text { Sowing rates for pasture seed } \\
\text { mixtures }\end{array}$ & $\begin{array}{l}40 \mathrm{lb} / \mathrm{ac} \text { was unnecessary; } 20 \\
\mathrm{lb} / \mathrm{ac} \text { was all that was needed }\end{array}$ & $\begin{array}{l}\text { Allo \& Jordan } 1957 \text { - NZGA } \\
\text { Vol. } 19\end{array}$ \\
\hline $\begin{array}{l}\text { Use of herbicides in pasture } \\
\text { re-sowing }\end{array}$ & $\begin{array}{l}\text { Direct drilling into herbicide } \\
\text { treated pasture }\end{array}$ & Matthews 1957 - NZGA Vol. 19 \\
\hline $\begin{array}{l}\text { Impact of treading damage } \\
\text { on pasture growth }\end{array}$ & $\begin{array}{l}\text { Treading reduced pasture yield } \\
\text { irrespective of soil condition - } \\
\text { exacerbated by wet conditions }\end{array}$ & Edmond 1957 - NZGA Vol. 19 \\
\hline $\begin{array}{l}\text { S deficiency in the South } \\
\text { Island }\end{array}$ & $\begin{array}{l}\text { Need for a range of fertiliser } \\
\text { with varying ratios of } S \text { and } P\end{array}$ & Walker 1957 - NZGA Vol. 19 \\
\hline $\begin{array}{l}\text { Early example of gauging } \\
\text { uptake of technology by } \\
\text { farmers - use of H1 short } \\
\text { rotation ryegrass }\end{array}$ & $\begin{array}{l}\text { Over } 90 \% \text { of farmers in some } \\
\text { regions (Otago and Southland) } \\
\text { were using H1 }\end{array}$ & Scott 1957 - NZGA Vol. 19 \\
\hline Breeding of Lotus uliginosus & $\begin{array}{l}\text { Lead to the production of Maku } \\
\text { lotus }\end{array}$ & Barclay 1957 - NZGA Vol. 19 \\
\hline $\begin{array}{l}\text { Impact of light into pastures } \\
\text { on growth rate }\end{array}$ & $\begin{array}{l}\text { Influence of defoliation height } \\
\text { on net assimilation rate and } \\
\text { therefore ability of plants to } \\
\text { 'harvest' light energy }\end{array}$ & $\begin{array}{l}\text { Brougham } 1957 \text { - NZGA Vol. } \\
19\end{array}$ \\
\hline $\begin{array}{l}\text { Commercialisation of legume } \\
\text { seed coating with rhizobia }\end{array}$ & $\begin{array}{l}\text { Improved nodulation of pasture } \\
\text { legumes }\end{array}$ & Callaghan 1958 - NZGA Vol. 20 \\
\hline $\begin{array}{l}\text { Sowing rates of perennial } \\
\text { ryegrass pastures are } \\
\text { generally too high, } \\
\text { suppressing the } \\
\text { establishment of other sown } \\
\text { species }\end{array}$ & $\begin{array}{l}\text { Sowing rates can be reduced } \\
\text { with negative effects on pasture } \\
\text { establishment }\end{array}$ & Cullen 1958 - NZGA Vol. 20 \\
\hline $\begin{array}{l}\text { Residual effect of applied } \\
\text { phosphatic fertilisers }\end{array}$ & $\begin{array}{l}\text { Residual effects can last many } \\
\text { years, but they can vary with soil } \\
\text { type and fertiliser type. Fresh } \\
\text { applications are more effective, }\end{array}$ & $\begin{array}{l}\text { Karlovsky } 1959 \text { - NZGA Vol. } \\
21\end{array}$ \\
\hline $\begin{array}{l}\text { Reviewing plant breeding } \\
\text { targets }\end{array}$ & $\begin{array}{l}\text { Identified seasonality of } \\
\text { production, water use efficiency, } \\
\text { competitive ability, and quality } \\
\text { as the main breeding targets }\end{array}$ & Barclay 1959 - NZGA Vol. 21 \\
\hline $\begin{array}{l}\text { Increased incidence of } \\
\text { animal disorders on } \\
\text { improved pasture and } \\
\text { incidence of Se deficiency }\end{array}$ & $\begin{array}{l}\text { Awareness of cause of some } \\
\text { animal disorders and need for Se } \\
\text { administration }\end{array}$ & Hartley 1959 - NZGA Vol. 21 \\
\hline $\begin{array}{l}\text { Use of the forage harvester to } \\
\text { cut and collect silage }\end{array}$ & $\begin{array}{l}\text { Improved productivity - labour } \\
\text { efficiency }\end{array}$ & Hopewell 1960 - NZGA Vol. 22 \\
\hline $\begin{array}{l}\text { Use of } \mathrm{Se}, \mathrm{Cu}, \mathrm{Co} \text { and } \mathrm{I} \text { as } \\
\text { micronutrients for sheep } \\
\text { health in Southland }\end{array}$ & $\begin{array}{l}\text { Improved production and } \\
\text { profitability }\end{array}$ & Andrews 1960 - NZGA Vol. 22 \\
\hline $\begin{array}{l}\text { Depletion and erosion of } \\
\text { pastoral tussock country - } \\
\text { remediation measures }\end{array}$ & $\begin{array}{l}\text { Improved sustainability of } \\
\text { production }\end{array}$ & Sly 1960 - NZGA Vol. 22 \\
\hline $\begin{array}{l}\text { Discovery (1959) of } \\
\text { Argentine stem weevil and }\end{array}$ & $\begin{array}{l}\text { Prairie grass suggested as an } \\
\text { alternative }\end{array}$ & Pantall 1961 - NZGA Vol. 23 \\
\hline
\end{tabular}




\begin{tabular}{|c|c|c|}
\hline Technology/advance & Impact/significance & Date - NZGA Proceedings \\
\hline \multicolumn{3}{|l|}{$\begin{array}{l}\text { its impact on ryegrass } \\
\text { survival }\end{array}$} \\
\hline $\begin{array}{l}\text { Leaching loss from high } \\
\text { concentrations of } \mathrm{N} \text { and } \mathrm{K} \text { in } \\
\text { sheep urine }\end{array}$ & $\begin{array}{l}\text { Use plant species that are } \\
\text { productive and can utilise these } \\
\text { nutrients }\end{array}$ & \begin{tabular}{|l|} 
Dale 1961 - NZGA Vol. 23 \\
\end{tabular} \\
\hline $\begin{array}{l}\text { Controlled versus } \\
\text { uncontrolled grazing in dairy } \\
\text { (McMeekan trials) }\end{array}$ & $\begin{array}{l}\text { Better pasture utilisation and per } \\
\text { cow production }\end{array}$ & Wallace 1961 - NZGA Vol. 23 \\
\hline Sheep electric fence & $\begin{array}{l}\text { More flexible and cheaper } \\
\text { subdivision }\end{array}$ & Currie 1961 - NZGA Vol. 23 \\
\hline $\begin{array}{l}\text { Integrating topdressing of } \\
\text { fertiliser with appropriate } \\
\text { subdivision }\end{array}$ & $\begin{array}{l}\text { More efficient use of additional } \\
\text { grass produced by fertiliser }\end{array}$ & \begin{tabular}{|l|} 
Currie 1961 - NZGA Vol. 23 \\
\end{tabular} \\
\hline Bulldozed tracks onto farms & $\begin{array}{l}\text { Allowed vehicles into otherwise } \\
\text { inaccessible parts of the farm - } \\
\text { improved subdivision and } \\
\text { management }\end{array}$ & Currie 1961 - NZGA Vol. 23 \\
\hline $\begin{array}{l}\text { Mg deficiency of some NZ } \\
\text { pasture soils }\end{array}$ & Improved production & Moody 1962 - NZGA Vol. 24 \\
\hline $\begin{array}{l}\text { Use of Yorkshire Fog on hill } \\
\text { country }\end{array}$ & $\begin{array}{l}\text { Breeding programme began at } \\
\text { Massey }\end{array}$ & Jacques 1962 - NZGA Vol. 24 \\
\hline $\begin{array}{l}\text { On pumice soils lucerne } \\
\text { nodulation only occurred } \\
\text { with liming }\end{array}$ & Improved N-fixation and yield & Parle 1962 - NZGA Vol. 24 \\
\hline $\begin{array}{l}\text { Significance of lucerne in dry } \\
\text { land areas for hay and } \\
\text { grazing }\end{array}$ & $\begin{array}{l}\text { Higher feed production in dry } \\
\text { land areas }\end{array}$ & Flay 1962 - NZGA Vol. 24 \\
\hline $\begin{array}{l}\text { Integration of sheep and } \\
\text { cattle grazing on hill country }\end{array}$ & $\begin{array}{l}\text { Improved productivity from } \\
\text { sheep }\end{array}$ & Ward 1962 - NZGA Vol. 24 \\
\hline $\begin{array}{l}\text { Herbicide alone will not } \\
\text { control weed problems }\end{array}$ & $\begin{array}{l}\text { Need for improved fertiliser } \\
\text { inputs ad pasture management - } \\
\text { also mentioned possible impact } \\
\text { of biocontrol }\end{array}$ & Leonard 1962 - NZGA Vol. 24 \\
\hline $\begin{array}{l}\text { Complementary nutrient } \\
\text { status of clovers and grass in } \\
\text { pasture }\end{array}$ & $\begin{array}{l}\text { Need to keep an appropriately } \\
\text { balanced grass:clover ratio }\end{array}$ & Johns 1963 - NZGA Vol. 25 \\
\hline $\begin{array}{l}\text { Widespread use of DDT to } \\
\text { control grass grub }\end{array}$ & $\begin{array}{l}\text { Potential residue issues } \\
\text { mentioned }\end{array}$ & Cottier 1963 - NZGA Vol. 25 \\
\hline $\begin{array}{l}\text { Integration of pasture } \\
\text { management and animal } \\
\text { husbandry for improved } \\
\text { pasture utilisation }\end{array}$ & $\begin{array}{l}\text { Improved pasture utilisation and } \\
\text { yield per hectare }\end{array}$ & Campbell 1963 - NZGA Vol. 25 \\
\hline $\begin{array}{l}\text { Release of Ariki - the new } \\
\text { long rotation ryegrass or } \\
\text { hybrid ryegrass }\end{array}$ & $\begin{array}{l}\text { Improved seasonal growth, } \\
\text { particularly in summer }\end{array}$ & Barclay 1963 - NZGA Vol. 25 \\
\hline $\begin{array}{l}\text { Improved pelleting of clover } \\
\text { seed with rhizobium }\end{array}$ & $\begin{array}{l}\text { Improved nodulation and } \\
\text { establishment of clover }\end{array}$ & Hastings 1964 - NZGA Vol. 26 \\
\hline $\begin{array}{l}\text { Rhizobium strain specificity } \\
\text { among pasture legume } \\
\text { species }\end{array}$ & $\begin{array}{l}\text { Requirement to use the right } \\
\text { rhizobium strain with the } \\
\text { appropriate legume species }\end{array}$ & $\begin{array}{l}\text { Greenwood } 1964 \text { - NZGA Vol. } \\
26\end{array}$ \\
\hline $\begin{array}{l}\text { Discovery of Pithomyces } \\
\text { chartarum fungus as the } \\
\text { cause of facial eczema }\end{array}$ & $\begin{array}{l}\text { Methods for reducing dead } \\
\text { matter in pasture for the fungus } \\
\text { to grow on }\end{array}$ & $\begin{array}{l}\text { Lancashire \& Keogh } 1964 \text { - } \\
\text { NZGA Vol. } 26\end{array}$ \\
\hline
\end{tabular}




\begin{tabular}{|c|c|c|}
\hline Technology/advance & Impact/significance & Date - NZGA Proceedings \\
\hline $\begin{array}{l}\text { (Thornton and Percival 1959) } \\
\text { through production of } \\
\text { sporidesmin }\end{array}$ & & \\
\hline $\begin{array}{l}\text { Identification of cellulose } \\
\text { content and leaf strength as } \\
\text { an important component of } \\
\text { pasture quality }\end{array}$ & $\begin{array}{l}\text { Indicates need for breeding } \\
\text { targets for increased grass feed } \\
\text { quality }\end{array}$ & Bailey 1964 - NZGA Vol. 26 \\
\hline $\begin{array}{l}\text { Management strategy for } \\
\text { high production from hill } \\
\text { country }\end{array}$ & Maintained improved production & Suckling 1964 - NZGA Vol. 26 \\
\hline $\begin{array}{l}\text { Use of popular trees to } \\
\text { stabilise steep land }\end{array}$ & Soil conservation & Hogg 1965 - NZGA Vol. 27 \\
\hline $\begin{array}{l}\text { Use of brassicas and cereals } \\
\text { as feed (in the North Island) }\end{array}$ & Increased production & Smith 1965 - NZGA Vol. 27 \\
\hline Sulphurised superphosphate & $\begin{array}{l}\text { Improved nutrition of pasture } \\
\text { grasses and legumes }\end{array}$ & Ludecke 1965 - NZGA Vol. 27 \\
\hline Vacuum silage & $\begin{array}{l}\text { Better silage conservation and } \\
\text { more efficient meat and wool } \\
\text { production }\end{array}$ & Monteath 1966 - NZGA Vol. 28 \\
\hline $\begin{array}{l}\text { Use of computers signalled } \\
\text { in keeping farm records and } \\
\text { decision making }\end{array}$ & Improved productivity & Banfield 1966 - NZGA Vol. 28 \\
\hline $\begin{array}{l}\text { Grasslands } 4707 \text { tetraploid } \\
\text { Westerwolds ryegrass }\end{array}$ & Improved annual ryegrass & $\begin{array}{l}\text { Barclay \& Vartha } 1966 \text { - NZGA } \\
\text { Vol. } 28\end{array}$ \\
\hline $\begin{array}{l}\text { The importance of } \\
\text { earthworms in maintaining } \\
\text { good soil structure }\end{array}$ & Improved production & Stockdill 1966 - NZGA Vol. 28 \\
\hline $\begin{array}{l}\text { Lime pelleting of legume } \\
\text { seed }\end{array}$ & Improved nodulation on acid soil & $\begin{array}{l}\text { Cullen \& Ludecke } 1966 \text { - } \\
\text { NZGA Vol. } 28\end{array}$ \\
\hline $\begin{array}{l}\text { Use of non-toxic tall fescue } \\
\text { in NZ }\end{array}$ & A safe alternative to toxic fescue & $\begin{array}{l}\text { All \& Southon } 1967 \text { - NZGA } \\
\text { Vol. } 29\end{array}$ \\
\hline $\begin{array}{l}\text { Demonstration of differing } \\
\text { nutritive value of ryegrass } \\
\text { cultivars }\end{array}$ & $\begin{array}{l}\text { Higher milk yields associated } \\
\text { with low crude fibre content and } \\
\text { high organic matter digestibility } \\
\text { of ryegrass cultivars }\end{array}$ & Wilson 1967 - NZGA Vol. 29 \\
\hline $\begin{array}{l}\text { Importance of pasture } \\
\text { utilisation }\end{array}$ & $\begin{array}{l}\text { Increased productivity per } \\
\text { hectare }\end{array}$ & Edmond 1967 - NZGA Vol. 29 \\
\hline $\begin{array}{l}\text { Economic success of NZ } \\
\text { pasture seed industry reliant } \\
\text { on export sales }\end{array}$ & $\begin{array}{l}\text { Need to get cultivars adopted to } \\
\text { overseas markets and improve } \\
\text { seed yields to improve efficiency }\end{array}$ & Shillito 1968 - NZGA Vol. 30 \\
\hline $\begin{array}{l}\text { Crown rust limiting pasture } \\
\text { production }\end{array}$ & $\begin{array}{l}\text { Need for cultivars selected for } \\
\text { rust resistance }\end{array}$ & $\begin{array}{l}\text { Lancashire \& Latch } 1968 \text { - } \\
\text { NZGA Vol. } 30\end{array}$ \\
\hline $\begin{array}{l}\text { Improved technology for } \\
\text { inoculating clover seed with } \\
\text { rhizobia }\end{array}$ & Improved nodulation & $\begin{array}{l}\text { Taylor \& Lloyd } 1968 \text { - NZGA } \\
\text { Vol. } 30\end{array}$ \\
\hline $\begin{array}{l}\text { Mangere ecotype of ryegrass } \\
\text { identified }\end{array}$ & $\begin{array}{l}\text { Higher production and drought } \\
\text { tolerance }\end{array}$ & Rumball 1969 - NZGA Vol. 31 \\
\hline $\begin{array}{l}\text { Grasslands } 4700 \text { (Pitau) } \\
\text { white clover }\end{array}$ & Improved winter growth & Barclay 1969 - NZGA Vol. 31 \\
\hline $\begin{array}{l}\text { Light rates of paraquat } \\
\text { spraying onto pasture }\end{array}$ & Improved clover content & $\begin{array}{l}\text { Williams \& Palmer } 1969 \text { - } \\
\text { NZGA Vol. } 31\end{array}$ \\
\hline $\begin{array}{l}\text { Length of recovery period } \\
\text { more important than cutting }\end{array}$ & $\begin{array}{l}\text { Improved yields and persistence } \\
\text { from lucerne }\end{array}$ & $\begin{array}{l}\text { Langer \& Keoghan } 1970 \text { - } \\
\text { NZGA Vol. } 32\end{array}$ \\
\hline
\end{tabular}




\begin{tabular}{|c|c|c|}
\hline Technology/advance & Impact/significance & Date - NZGA Proceedings \\
\hline \multicolumn{3}{|l|}{ height for lucerne survival } \\
\hline $\begin{array}{l}\text { Researchers encouraged to } \\
\text { evaluate the cost of } \\
\text { maximising production, not } \\
\text { just the likely return }\end{array}$ & $\begin{array}{l}\text { Importance of economics in } \\
\text { introducing new technologies to } \\
\text { increase production }\end{array}$ & Campbell 1970 - NZGA Vol. 32 \\
\hline $\begin{array}{l}\text { Over-drilling annual } \\
\text { ryegrasses into lucerne }\end{array}$ & $\begin{array}{l}\text { Improved total and seasonal } \\
\text { forage yields }\end{array}$ & Vartha 1971 - NZGA Vol. 33 \\
\hline $\begin{array}{l}\text { Using fertiliser } \mathrm{N} \text { to } \\
\text { overcome seasonal shortages } \\
\text { in } \mathrm{N} \text { supply from } \mathrm{N} \text {-fixation }\end{array}$ & Improved seasonal forage yields & O’Connor 1971 - NZGA Vol. 33 \\
\hline $\begin{array}{l}\text { Lucerne identified as a } \\
\text { valuable crop in the humid } \\
\text { North Island }\end{array}$ & Highly value feed & $\begin{array}{l}\text { Robinson \& Abbott } 1971 \text { - } \\
\text { NZGA Vol. } 33\end{array}$ \\
\hline Electronic capacitance meter & $\begin{array}{l}\text { Measurement of pasture yields - } \\
\text { although reliability was an issue }\end{array}$ & $\begin{array}{l}\text { Bryant et al. 1971; } \\
\text { Stephen \& Revfeim } 1971 \text { - } \\
\text { NZGA Vol. } 33 \\
\end{array}$ \\
\hline Weighted disc grass meter & Measurement of pasture yields & $\begin{array}{l}\text { Phillips \& Clarke } 1971 \text { - NZGA } \\
\text { Vol. } 33\end{array}$ \\
\hline $\begin{array}{l}\text { All grass wintering in } \\
\text { Southland }\end{array}$ & $\begin{array}{l}\text { Overcame dissatisfaction with } \\
\text { swedes }\end{array}$ & $\begin{array}{l}\text { Brown \& Harris 1972; Miller } \\
\text { 1972; Halford } 1972 \text { - NZGA } \\
\text { Vol. } 34 \\
\end{array}$ \\
\hline $\begin{array}{l}\text { Feed budgeting on dairy } \\
\text { farms }\end{array}$ & $\begin{array}{l}\text { Improved feeding, productivity } \\
\text { and production leading increased } \\
\text { economic returns }\end{array}$ & Parker 1972 - NZGA Vol. 34 \\
\hline $\begin{array}{l}\text { Use of cereal forage with } \\
\text { annual ryegrass }\end{array}$ & $\begin{array}{l}\text { Improved forage yield on } \\
\text { summer dry areas }\end{array}$ & $\begin{array}{l}\text { Vartha \& Rae } 1972 \text { - NZGA } \\
\text { Vol. } 34\end{array}$ \\
\hline $\begin{array}{l}\text { "Block" or "long rotation" } \\
\text { wintering }\end{array}$ & Improved winter production & $\begin{array}{l}\text { Parker \& Willis } 1972 \text { - NZGA } \\
\text { Vol. } 34\end{array}$ \\
\hline $\begin{array}{l}\text { Grasses are more effective in } \\
\text { obtaining soil } \mathrm{P} \text { than white } \\
\text { clover }\end{array}$ & $\begin{array}{l}\text { Better understanding of nutrition } \\
\text { requirements of white clover }\end{array}$ & $\begin{array}{l}\text { Jackman \& Mouat } 1973 \text { - } \\
\text { NZGA Vol. } 35\end{array}$ \\
\hline $\begin{array}{l}\text { Lax grazing can cause } \\
\text { browntop to be suppressed }\end{array}$ & $\begin{array}{l}\text { Means of managing browntop } \\
\text { ingress }\end{array}$ & Harris 1973 - NZGA Vol. 35 \\
\hline $\begin{array}{l}\text { Use of mineral } \mathrm{N} \text { on hill } \\
\text { country }\end{array}$ & Identified as an economic option & $\begin{array}{l}\text { Sherlock \& O’Connor } 1973 \text { - } \\
\text { NZGA Vol. } 35\end{array}$ \\
\hline $\begin{array}{l}\text { Mangere ecotype ryegrass } \\
\text { identified as superior to } \\
\text { certified strains }\end{array}$ & Improved pasture production & Ellett 1973 - NZGA Vol. 35 \\
\hline $\begin{array}{l}\text { Spring grazing management } \\
\text { of lucerne }\end{array}$ & $\begin{array}{l}\text { Improved lucerne growth on } \\
\text { light soils }\end{array}$ & Janson 1974 - NZGA Vol. 36 \\
\hline Browse shrubs & $\begin{array}{l}\text { Increase production on low } \\
\text { producing hill country }\end{array}$ & Hill 1974 - NZGA Vol. 36 \\
\hline Irrigated lucerne & $\begin{array}{l}\text { Improved feed in spring/summer } \\
\text { on irrigated light soils }\end{array}$ & Janson 1974 - NZGA Vol. 36 \\
\hline Tall fescue in dryland & Improved production & Watkins 1974 - NZGA Vol. 36 \\
\hline $\begin{array}{l}\text { Tall fescue as a companion } \\
\text { grass to lucerne }\end{array}$ & Improved production & $\begin{array}{l}\text { Allen \& Cullen } 1974 \text { - NZGA } \\
\text { Vol. } 36\end{array}$ \\
\hline $\begin{array}{l}\text { Release G4710 tall fescue } \\
\text { (Grasslands Roa) }\end{array}$ & $\begin{array}{l}\text { Better adapted tall fescue } \\
\text { germplasm }\end{array}$ & Anderson 1974 - NZGA Vol. 36 \\
\hline $\begin{array}{l}\text { Establishment of alkali and } \\
\text { leafcutter bees in NZ }\end{array}$ & Improved pollination of lucerne & Donovan 1974 - NZGA Vol. 36 \\
\hline Plant Breeders Rights & $\begin{array}{l}\text { Intellectual property protection } \\
\text { of bred cultivars }\end{array}$ & \begin{tabular}{|l} 
Lancashire 1976 - NZGA Vol. \\
37
\end{tabular} \\
\hline
\end{tabular}




\begin{tabular}{|c|c|c|}
\hline Technology/advance & Impact/significance & Date - NZGA Proceedings \\
\hline $\begin{array}{l}\text { Integrating forestry and } \\
\text { pasture grazing }\end{array}$ & Improved profitability & $\begin{array}{l}\text { Gillingham et al. } 1976 \text {; } \\
\text { Farnsworth et al. } 1976 \text { - NZGA } \\
\text { Vol. } 37\end{array}$ \\
\hline $\begin{array}{l}\text { Identification of chemical } \\
\text { deterrents in roots of lucerne } \\
\text { and lotus }\end{array}$ & $\begin{array}{l}\text { Grass grub and black beetle } \\
\text { resistance }\end{array}$ & $\begin{array}{l}\text { Sutherland } 1976 \text { - NZGA Vol. } \\
37\end{array}$ \\
\hline Over-drilled cereal forages & Improved yields & $\begin{array}{l}\text { McLeod \& Douglas } 1976 \text { - } \\
\text { NZGA Vol. } 37\end{array}$ \\
\hline Lotus for high land acid soils & Legume adapted to acid soils & $\begin{array}{l}\text { Nordmeyer \& Davis } 1977 \text { - } \\
\text { NZGA Vol. } 38\end{array}$ \\
\hline Tannins in some legume & $\begin{array}{l}\text { Reduction in incidence of bloat } \\
\text { and improved nutritive value }\end{array}$ & $\begin{array}{l}\text { Ulyatt et al. } 1977 \text { - NZGA Vol. } \\
38\end{array}$ \\
\hline $\begin{array}{l}\text { Tetraploid red clover - } \\
\text { Grasslands Pawera }\end{array}$ & $\begin{array}{l}\text { Productive late flowering red } \\
\text { clover }\end{array}$ & Anderson 1977 - NZGA Vol. 38 \\
\hline $\begin{array}{l}\text { Remote sensing to measure } \\
\text { pasture production }\end{array}$ & $\begin{array}{l}\text { Improved pasture growth } \\
\text { analysis }\end{array}$ & Cochrane 1977 - NZGA Vol. 38 \\
\hline Matua prairie grass & $\begin{array}{l}\text { Special purpose pasture grass } \\
\text { option }\end{array}$ & Rys et al. 1978 - NZGA Vol. 39 \\
\hline $\begin{array}{l}\text { Lucerne and lucerne/prairie } \\
\text { grass swards on pumice soils }\end{array}$ & High yield, high quality pasture & $\begin{array}{l}\text { Marsh \& Brunswick } 1978 \text { - } \\
\text { NZGA Vol. } 39\end{array}$ \\
\hline $\begin{array}{l}\text { Use of green feeds (cereal } \\
\text { forages) in Southland }\end{array}$ & Improved winter feed supply & $\begin{array}{l}\text { Hay \& Ryan } 1978 \text { - NZGA Vol. } \\
39\end{array}$ \\
\hline Water harvesting & $\begin{array}{l}\text { Improved water supply in } \\
\text { summer - method of } \\
\text { rationalising natural water } \\
\text { supply }\end{array}$ & $\begin{array}{l}\text { Lowe 1978; Bowler \& Turner } \\
1978 \text { - NZGA Vol. } 39\end{array}$ \\
\hline $\begin{array}{l}\text { Importance of 'safe' pasture } \\
\text { (low levels of parasitic } \\
\text { larvae) for lamb growth rates }\end{array}$ & Improved lamb growth rate & Jagger 1979 - NZGA Vol. 40 \\
\hline $\begin{array}{l}\mathrm{N} \text { provision through } \\
\text { mineralisation and } \mathrm{N} \text {-fixation }\end{array}$ & $\begin{array}{l}\text { Two major processes for } \mathrm{N} \\
\text { provision for grass growth }\end{array}$ & Carran 1979 - NZGA Vol. 40 \\
\hline Direct drilling of grasses & Cost effective pasture renovation & $\begin{array}{l}\text { Ryan et al. } 1979 \text { - NZGA Vol. } \\
40\end{array}$ \\
\hline $\begin{array}{l}\text { Association between black } \\
\text { beetle presence and paspalum }\end{array}$ & Increased pasture pest burden & $\begin{array}{l}\text { Watson \& Wrenn } 1980 \text { - NZGA } \\
\text { Vol. } 41\end{array}$ \\
\hline Forest farming & $\begin{array}{l}\text { Integration of different } \\
\text { production systems }\end{array}$ & $\begin{array}{l}\text { Hawke et al. } 1980 \text { - NZGA Vol. } \\
41\end{array}$ \\
\hline $\begin{array}{l}\text { Competitive ability of } \\
\text { naturalised rhizobium strains }\end{array}$ & $\begin{array}{l}\text { Explanation for the often poor } \\
\text { nodulation of rhizobium } \\
\text { inoculated legume seed }\end{array}$ & Hale 1980 - NZGA Vol. 41 \\
\hline Grasslands Roa tall fescue & $\begin{array}{l}\text { Improved late summer early } \\
\text { autumn production }\end{array}$ & $\begin{array}{l}\text { Goold et al. } 1980 \text { - NZGA Vol. } \\
41\end{array}$ \\
\hline $\begin{array}{l}\text { Susceptibility of white clover } \\
\text { and ryegrass to grass grub }\end{array}$ & $\begin{array}{l}\text { Option to use resistant species - } \\
\text { lucerne, lotus and fescue }\end{array}$ & $\begin{array}{l}\text { East et al. } 1980 \text { - NZGA Vol. } \\
41\end{array}$ \\
\hline $\begin{array}{l}\text { Intensity of pasture grazing } \\
\text { to manipulate paspalum } \\
\text { content }\end{array}$ & $\begin{array}{l}\text { Option to reduce paspalum } \\
\text { content }\end{array}$ & $\begin{array}{l}\text { Baars et al. } 1980 \text { - NZGA Vol. } \\
41\end{array}$ \\
\hline $\begin{array}{l}\text { Use of grazing to 'control' } \\
\text { aphid populations on lucerne }\end{array}$ & $\begin{array}{l}\text { Reduced damage from aphids } \\
\text { and viruses }\end{array}$ & $\begin{array}{l}\text { Smallfield et al. } 1980 \text { - NZGA } \\
\text { Vol. } 41\end{array}$ \\
\hline $\begin{array}{l}\text { Procedure for high grass seed } \\
\text { yields }\end{array}$ & Improved grass seed yields & $\begin{array}{l}\text { Brown 1980; Moore 1980; } \\
\text { Lancashire et al. } 1980 \text { - R\&PS } \\
\text { Vol. } 1\end{array}$ \\
\hline Amenity seed production & Improved amenity grass seed & Corkill \& Rumball 1980 - \\
\hline
\end{tabular}




\begin{tabular}{|c|c|c|}
\hline Technology/advance & Impact/significance & Date - NZGA Proceedings \\
\hline strategy & yields & GR\&PS Vol.1 \\
\hline $\begin{array}{l}\text { Procedure for high white } \\
\text { clover seed yields }\end{array}$ & $\begin{array}{l}\text { Improved white clover seed } \\
\text { yield }\end{array}$ & $\begin{array}{l}\text { Clifford 1980; Wright 1980; Lay } \\
1980 \text { - GR\&PS Vol.1 }\end{array}$ \\
\hline $\begin{array}{l}\text { Procedure for high red clover } \\
\text { seed yields }\end{array}$ & Improved red clover seed yield & $\begin{array}{l}\text { Clifford \& Anderson - GR\&PS } \\
\text { Vol.1 }\end{array}$ \\
\hline $\begin{array}{l}\text { Procedure for high lotus seed } \\
\text { yields }\end{array}$ & Improved lotus seed yields & $\begin{array}{l}\text { Lancashire et al. } 1980 \text { - GR\&PS } \\
\text { Vol.1 }\end{array}$ \\
\hline $\begin{array}{l}\text { Procedure for high lucerne } \\
\text { seed yields }\end{array}$ & Improved lucerne seed yields & $\begin{array}{l}\text { Palmer \& Donovan } 1980 \text { - } \\
\text { GR\&PS Vol.1 }\end{array}$ \\
\hline $\begin{array}{l}\text { The role of lotus as a pioneer } \\
\text { species }\end{array}$ & Better pastures on difficult soils & \begin{tabular}{|l} 
Morton 1980; Scott \& Mills \\
1981 - NZGA Vol. 42 \\
\end{tabular} \\
\hline $\begin{array}{l}\text { Legume oversowing and } \\
\text { fertiliser reduced Hieracium }\end{array}$ & Reduction of an invasive weed & $\begin{array}{l}\text { Lucas et al. } 1981 \text { - NZGA Vol. } \\
42\end{array}$ \\
\hline $\begin{array}{l}\text { High feeding value of tannin } \\
\text { containing legumes }\end{array}$ & Better quality feed & $\begin{array}{l}\text { John \& Lancashire } 1981 \text { - } \\
\text { NZGA Vol. } 42\end{array}$ \\
\hline $\begin{array}{l}\text { Reliance on overseas } \\
\text { germplasm for NZ pasture } \\
\text { improvement }\end{array}$ & Improved pasture cultivars & $\begin{array}{l}\text { Corkill et al. } 1981 \text { - NZGA Vol. } \\
42\end{array}$ \\
\hline $\begin{array}{l}\text { Selective fertiliser } \\
\text { application }\end{array}$ & $\begin{array}{l}\text { Improved efficiency of } \\
\text { superphosphate use }\end{array}$ & $\begin{array}{l}\text { Lambert et al. } 1982 \text { - NZGA } \\
\text { Vol. } 43\end{array}$ \\
\hline $\begin{array}{l}\text { Fungicide seed treatment to } \\
\text { aid grass establishment }\end{array}$ & $\begin{array}{l}\text { Improved establishment of } \\
\text { pastures }\end{array}$ & Falloon 1982 - NZGA Vol. 43 \\
\hline $\begin{array}{l}\text { Value of Grasslands Nui and } \\
\text { Ellet ryegrasses on fertile } \\
\text { soils }\end{array}$ & Improved productivity & Goold 1982 - NZGA Vol. 43 \\
\hline $\begin{array}{l}\mathrm{N} \text { cycle in pasture quantified } \\
\text { with losses from urine } \\
\text { patches identified as an } \\
\text { inefficiency }\end{array}$ & $\begin{array}{l}\text { Understanding of where } \mathrm{N} \text { losses } \\
\text { occur }\end{array}$ & $\begin{array}{l}\text { Field \& Ball } 1982 \text { - NZGA Vol. } \\
43\end{array}$ \\
\hline $\begin{array}{l}\text { MCPB and mechanical } \\
\text { topping to control } \\
\text { Californian thistle }\end{array}$ & $\begin{array}{l}\text { Improved pastures and } \\
\text { production }\end{array}$ & $\begin{array}{l}\text { Hartley \& Thomson } 1982 \text { - } \\
\text { NZGA Vol. } 43\end{array}$ \\
\hline $\begin{array}{l}\text { Hill country white clover } \\
\text { selected and released }\end{array}$ & $\begin{array}{l}\text { Improved clover content and } \\
\text { persistence in hill country }\end{array}$ & $\begin{array}{l}\text { Williams et al. } 1982 \text { - NZGA } \\
\text { Vol. } 43\end{array}$ \\
\hline $\begin{array}{l}\text { Hill country management } \\
\text { complements pasture quality }\end{array}$ & Improved production & \begin{tabular}{|l} 
Clark et al. 1982 - NZGA Vol. \\
43
\end{tabular} \\
\hline $\begin{array}{l}\text { Gorse control through } \\
\text { goat/sheep mob grazing }\end{array}$ & Improved pasture quality & $\begin{array}{l}\text { Rolston et al. } 1982 \text { - NZGA } \\
\text { Vol. } 43\end{array}$ \\
\hline $\begin{array}{l}\text { Use of phalaris, tall fescue, } \\
\text { cocksfoot and chicory in } \\
\text { dryland pastures }\end{array}$ & $\begin{array}{l}\text { Improved production in dry } \\
\text { regions }\end{array}$ & $\begin{array}{l}\text { Lancashire \& Brock } 1983 \text { - } \\
\text { NZGA Vol. } 44\end{array}$ \\
\hline Grasslands Roa tall fescue & $\begin{array}{l}\text { Improved tall fescue for dryland } \\
\text { regions }\end{array}$ & Brock 1983 - NZGA Vol. 44 \\
\hline $\begin{array}{l}\text { Grasslands Rere and } \\
\text { Grasslands Oranga lucerne }\end{array}$ & $\begin{array}{l}\text { Aphid resistant cultivars adapted } \\
\text { to NZ conditions }\end{array}$ & $\begin{array}{l}\text { Easton \& Stiefel } 1983 \text { - NZGA } \\
\text { Vol. } 44 \\
\end{array}$ \\
\hline Matua/Nui/Pawera pastures & $\begin{array}{l}\text { Improved cool season activity, } \\
\text { drought tolerance and summer } \\
\text { growth }\end{array}$ & $\begin{array}{l}\text { Hay \& Ryan } 1983 \text { - NZGA Vol. } \\
44\end{array}$ \\
\hline $\begin{array}{l}\text { Association of ryegrass } \\
\text { endophyte with ryegrass } \\
\text { staggers }\end{array}$ & $\begin{array}{l}\text { Identification of the likely cause } \\
\text { of ryegrass staggers }\end{array}$ & $\begin{array}{l}\text { Mortimer \& di Menna 1983; } \\
\text { Harvey 1983; Fletcher 1983- } \\
\text { NZGA Vol. } 44\end{array}$ \\
\hline $\begin{array}{l}\text { Endophyte in ryegrass } \\
\text { associated with resistance to }\end{array}$ & $\begin{array}{l}\text { Improved persistence and } \\
\text { production of ryegrass swards }\end{array}$ & $\begin{array}{l}\text { Gaynor \& Hunt } 1983 \text { - NZGA } \\
\text { Vol. } 44\end{array}$ \\
\hline
\end{tabular}




\begin{tabular}{|c|c|c|}
\hline Technology/advance & Impact/significance & Date - NZGA Proceedings \\
\hline \multicolumn{3}{|l|}{ Argentine stem weevil } \\
\hline $\begin{array}{l}\text { Use of fungicides to kill } \\
\text { endophytes in ryegrass plants } \\
\text { and seed }\end{array}$ & $\begin{array}{l}\text { Reduce impact of endophyte on } \\
\text { animal health }\end{array}$ & Latch 1983 - NZGA Vol. 44 \\
\hline $\begin{array}{l}\text { Breeding for staggers } \\
\text { resistance in sheep }\end{array}$ & $\begin{array}{l}\text { Reduce impact of ryegrass } \\
\text { staggers }\end{array}$ & Hewett 1983 - NZGA Vol. 44 \\
\hline $\begin{array}{l}\text { Need for testing endophyte } \\
\text { levels in ryegrass commercial } \\
\text { seed }\end{array}$ & $\begin{array}{l}\text { Prediction of impact on stock } \\
\text { health }\end{array}$ & Scott 1983 - NZGA Vol. 44 \\
\hline $\begin{array}{l}\text { Use of supplementary feed to } \\
\text { improve ewe flushing }\end{array}$ & Improved ovulation rate & $\begin{array}{l}\text { Hayman \& Munro } 1983 \text { - } \\
\text { NZGA Vol. } 44\end{array}$ \\
\hline $\begin{array}{l}\text { Lotus corniculatus for dry } \\
\text { hill and high country }\end{array}$ & Legume for dryland regions & $\begin{array}{l}\text { Scott \& Charlton } 1983 \text { - NZGA } \\
\text { Vol. } 44\end{array}$ \\
\hline $\begin{array}{l}\text { Complementary grazing of } \\
\text { sheep and goats on hill } \\
\text { country }\end{array}$ & $\begin{array}{l}\text { Improved meat and fibre } \\
\text { production }\end{array}$ & $\begin{array}{l}\text { Clark et al. } 1984 \text { - NZGA Vol. } \\
45\end{array}$ \\
\hline Sulla for soil conservation & Renovation of slips and gullies & Douglas 1984 - NZGA Vol. 45 \\
\hline $\begin{array}{l}\text { Differing rates of } \\
\text { volatilisation for } \mathrm{N} \text { fertilisers }\end{array}$ & $\begin{array}{l}\text { Less ammonia lost from } \\
\text { ammonium sulphate than urea }\end{array}$ & $\begin{array}{l}\text { Theobald \& Ball } 1984 \text { - NZGA } \\
\text { Vol. } 45\end{array}$ \\
\hline $\begin{array}{l}\text { Glyphosate herbicide as a } \\
\text { means of better pasture } \\
\text { management and } \\
\text { establishment on hill country }\end{array}$ & $\begin{array}{l}\text { Improved pasture quality and } \\
\text { animal production }\end{array}$ & $\begin{array}{l}\text { Arnst \& Park } 1984 \text { - NZGA Vol. } \\
45\end{array}$ \\
\hline $\begin{array}{l}\text { White clover stolon burial } \\
\text { peaks in early spring }\end{array}$ & $\begin{array}{l}\text { Understanding of the impact of } \\
\text { grazing on stolon damage }\end{array}$ & $\begin{array}{l}\text { Hay \& Chapman } 1984 \text { - NZGA } \\
\text { Vol. } 45\end{array}$ \\
\hline Reactive phosphate rock & $\begin{array}{l}\text { Viable option when the effective } \\
\mathrm{P} \text { cost is lower than that of } \\
\text { superphosphate }\end{array}$ & $\begin{array}{l}\text { Percival et al. } 1984 \text { - NZGA } \\
\text { Vol. } 45\end{array}$ \\
\hline $\begin{array}{l}\text { Use of fungicides and growth } \\
\text { retardants to increase grass } \\
\text { seed production }\end{array}$ & Increased grass seed yield & $\begin{array}{l}\text { Hampton et al. } 1985 \text { - GR\&PS } \\
\text { Vol. } 2\end{array}$ \\
\hline $\begin{array}{l}\text { Herbicide and fertiliser } \\
\text { recommendations for grass } \\
\text { seed crops }\end{array}$ & Increased grass seed yield & $\begin{array}{l}\text { Rolston et al } 1985 \text { - GR\&PS } \\
\text { Vol. } 2\end{array}$ \\
\hline $\begin{array}{l}\text { Relationship of leaf size to } \\
\text { seed yield in white clover }\end{array}$ & $\begin{array}{l}\text { Processes for reducing leaf size } \\
\text { in seed crops }\end{array}$ & Clifford 1985 - GR\&PS Vol. 2 \\
\hline $\begin{array}{l}\text { Process for following } \\
\text { cropping with white clover }\end{array}$ & $\begin{array}{l}\text { Successful white clovers seed } \\
\text { crop establishment }\end{array}$ & McCartin 1985 - GR\&PS Vol. 2 \\
\hline $\begin{array}{l}\text { Field heating and drying } \\
\text { damage impacts on seed } \\
\text { quality }\end{array}$ & $\begin{array}{l}\text { Need to avoid field heating and } \\
\text { drying damage }\end{array}$ & $\begin{array}{l}\text { Hill \& Johnstone } 1985 \text { - GR\&PS } \\
\text { Vol. } 2\end{array}$ \\
\hline $\begin{array}{l}\text { Process for successful } \\
\text { cultivar change for white } \\
\text { clover }\end{array}$ & $\begin{array}{l}\text { Reduced contamination of white } \\
\text { clover seed crops }\end{array}$ & $\begin{array}{l}\text { Clifford et al. } 1985 \text { - GR\&PS } \\
\text { Vol. } 2\end{array}$ \\
\hline $\begin{array}{l}\text { Ecology of forage species in } \\
\text { South Is. hill and high } \\
\text { country }\end{array}$ & $\begin{array}{l}\text { Species aligned for fitness of } \\
\text { purpose }\end{array}$ & $\begin{array}{l}\text { Scott et al. } 1985 \text { - GR\&PS Vol. } \\
3\end{array}$ \\
\hline $\begin{array}{l}\text { Process for establishing } \\
\text { pastures in high country }\end{array}$ & $\begin{array}{l}\text { Improved establishment and } \\
\text { management of high country } \\
\text { pastures }\end{array}$ & $\begin{array}{l}\text { Allan et al. } 1985 \text { - GR\&PS Vol. } \\
3\end{array}$ \\
\hline $\begin{array}{l}\text { Process for establishing } \\
\text { pastures in hill country }\end{array}$ & $\begin{array}{l}\text { Improved establishment and } \\
\text { management of hill country } \\
\text { pastures }\end{array}$ & $\begin{array}{l}\text { Chapman \& Macfarlane 1985; } \\
\text { Lambert et al. } 1985 \text { - GR\&PS } \\
\text { Vol. } 3\end{array}$ \\
\hline
\end{tabular}




\begin{tabular}{|c|c|c|}
\hline Technology/advance & Impact/significance & Date - NZGA Proceedings \\
\hline $\begin{array}{l}\text { Process for establishing } \\
\text { pastures in dryland }\end{array}$ & $\begin{array}{l}\text { Improved establishment and } \\
\text { management of dryland pastures }\end{array}$ & $\begin{array}{l}\text { Hoglund \& White 1985; Hume } \\
\text { \& Fraser } 1985 \text { - GR\&PS Vol. } 3 \\
\end{array}$ \\
\hline $\begin{array}{l}\text { Process for establishing } \\
\text { pastures on summer wet } \\
\text { finishing country }\end{array}$ & $\begin{array}{l}\text { Improved establishment and } \\
\text { management of finishing } \\
\text { pastures }\end{array}$ & $\begin{array}{l}\text { Harris \& Chu 1985; Cosgrove et } \\
\text { al. } 1985 \text { - GR\&PS Vol. } 3\end{array}$ \\
\hline $\begin{array}{l}\text { Process for establishing } \\
\text { pastures for dairying }\end{array}$ & $\begin{array}{l}\text { Improved establishment and } \\
\text { management of dairy grazing } \\
\text { pastures }\end{array}$ & $\begin{array}{l}\text { Goold et al.1985; Thom et al. } \\
1985 \text { - GR\&PS Vol. } 3\end{array}$ \\
\hline $\begin{array}{l}\text { Large N leaching losses } \\
\text { under intensive grazing }\end{array}$ & $\begin{array}{l}\text { Implications for ground water } \\
\text { quality }\end{array}$ & $\begin{array}{l}\text { Field et al. } 1985 \text { - NZGA Vol. } \\
46\end{array}$ \\
\hline $\begin{array}{l}\text { Grasslands Demand white } \\
\text { clover }\end{array}$ & White clover for southern NZ & Widdup 1985 - NZGA Vol. 46 \\
\hline $\begin{array}{l}\text { Annual cycle of white clover } \\
\text { stolon burial and re- } \\
\text { emergence }\end{array}$ & $\begin{array}{l}\text { Understanding clover growth in } \\
\text { grazed pastures }\end{array}$ & Hay 1985 - NZGA Vol. 46 \\
\hline $\begin{array}{l}\text { Increased flow rate and } \\
\text { reduced strip length improve } \\
\text { water use efficiency }\end{array}$ & Better irrigation in water use & $\begin{array}{l}\text { Taylor et al. } 1985 \text { - NZGA Vol. } \\
46\end{array}$ \\
\hline Shelter belts & Improved pasture production & Radcliffe 1985 - NZGA Vol. 46 \\
\hline $\begin{array}{l}\text { Negative relationship } \\
\text { between grazing intensity } \\
\text { and litter loss }\end{array}$ & $\begin{array}{l}\text { Increased } \mathrm{N} \text { loss with reduced } \\
\text { litter accumulation }\end{array}$ & Hoglund 1985 - NZGA Vol. 46 \\
\hline $\begin{array}{l}\text { Integrating red clover and } \\
\text { ryegrass }\end{array}$ & $\begin{array}{l}\text { Increased yield of high quality } \\
\text { pasture }\end{array}$ & $\begin{array}{l}\text { Cosgrove \& Brougham } 1985 \text { - } \\
\text { NZGA Vol. } 46\end{array}$ \\
\hline $\begin{array}{l}\text { Chemical manipulation of } \\
\text { hill country pastures }\end{array}$ & Improved clover content & $\begin{array}{l}\text { Rolston et al. } 1985 \text { - NZGA } \\
\text { Vol. } 46\end{array}$ \\
\hline $\begin{array}{l}\text { Use of Maku lotus at high } \\
\text { altitude }\end{array}$ & $\begin{array}{l}\text { Improved legume content in } \\
\text { swards }\end{array}$ & \begin{tabular}{|l|} 
Dunbar \& Costello 1985 - \\
NZGA Vol. 46 \\
\end{tabular} \\
\hline $\begin{array}{l}\mathrm{Zn} \text { dosing, avoidance of toxic } \\
\text { pastures and use of } \\
\text { fungicides to combat facial } \\
\text { eczema }\end{array}$ & $\begin{array}{l}\text { Strategy for reducing impact of } \\
\text { facial eczema }\end{array}$ & Towers 1986 - NZGA Vol. 47 \\
\hline $\begin{array}{l}\text { Peramine, the endophyte } \\
\text { alkaloid offering resistance to } \\
\text { Argentine stem weevil }\end{array}$ & $\begin{array}{l}\text { Understanding of endophyte } \\
\text { mediated resistance to the weevil }\end{array}$ & $\begin{array}{l}\text { Gaynor \& Rowan } 1986 \text { - NZGA } \\
\text { Vol. } 47\end{array}$ \\
\hline $\begin{array}{l}\text { Autumn and winter lambing } \\
\text { in Northland }\end{array}$ & $\begin{array}{l}\text { Increased flexibility in lamb } \\
\text { production }\end{array}$ & $\begin{array}{l}\text { Andrewes \& Taylor } 1986 \text { - } \\
\text { NZGA Vol. } 47\end{array}$ \\
\hline Rapid stock rotation & $\begin{array}{l}\text { Means of minimising impacts of } \\
\text { fungal toxins in pasture }\end{array}$ & Keogh 1986 - NZGA Vol. 47 \\
\hline $\begin{array}{l}\text { Earthworm activity increases } \\
\text { water soluble phosphate in } \\
\text { soil }\end{array}$ & Improved phosphate availability & $\begin{array}{l}\text { Mouat \& Keogh } 1986 \text { - NZGA } \\
\text { Vol. } 47\end{array}$ \\
\hline $\begin{array}{l}\text { Earthworm content and } \\
\text { pasture productivity } \\
\text { positively correlated in hill } \\
\text { country }\end{array}$ & $\begin{array}{l}\text { Method for increasing } \\
\text { earthworm population density }\end{array}$ & Lambert 1986 - NZGA Vol. 47 \\
\hline $\begin{array}{l}\text { Set stocking reduces grass } \\
\text { grub, but increased porina } \\
\text { and earthworm numbers }\end{array}$ & $\begin{array}{l}\text { Methods for managing pests and } \\
\text { earthworm population density }\end{array}$ & Brock 1986 - NZGA Vol. 47 \\
\hline $\begin{array}{l}\text { Distribution of clover cyst } \\
\text { and root knot nematodes in } \\
\text { pastures }\end{array}$ & $\begin{array}{l}\text { Understanding of their } \\
\text { distribution and importance in } \\
\text { clover survival and production }\end{array}$ & $\begin{array}{l}\text { Mercer \& Woodfield } 1986 \text { - } \\
\text { NZGA Vol. } 47\end{array}$ \\
\hline Significance of cricket & Cause of significant pasture & Blank 1986 - NZGA Vol. 47 \\
\hline
\end{tabular}




\begin{tabular}{|c|c|c|}
\hline Technology/advance & Impact/significance & Date - NZGA Proceedings \\
\hline $\begin{array}{l}\text { damage in Northland } \\
\text { pastures }\end{array}$ & production losses & \\
\hline $\begin{array}{l}\text { Pasture disappearance model } \\
\text { shows importance of pre- } \\
\text { grazing green pasture mass }\end{array}$ & $\begin{array}{l}\text { Means of achieving intake rate } \\
\text { targets }\end{array}$ & $\begin{array}{l}\text { McCall et al. } 1986 \text { - NZGA } \\
\text { Vol. } 47\end{array}$ \\
\hline $\begin{array}{l}\text { Pasture height as a measure } \\
\text { of pasture mass and animal } \\
\text { performance }\end{array}$ & $\begin{array}{l}\text { Assistance with management } \\
\text { decisions }\end{array}$ & $\begin{array}{l}\text { Webby \& Pengelly } 1986 \text { - } \\
\text { NZGA Vol. } 47\end{array}$ \\
\hline $\begin{array}{l}\text { Reducing paspalum content } \\
\text { and increasing grazing } \\
\text { interval increased ryegrass } \\
\text { seedling establishment }\end{array}$ & $\begin{array}{l}\text { Improved ryegrass establishment } \\
\text { when overdrilled }\end{array}$ & $\begin{array}{l}\text { Thom et al. } 1986 \text { - NZGA Vol. } \\
47\end{array}$ \\
\hline $\begin{array}{l}\text { MAF Fertiliser Advisory } \\
\text { Service }\end{array}$ & $\begin{array}{l}\text { Improved recommendation for } \\
\text { fertiliser use }\end{array}$ & $\begin{array}{l}\text { Cornforth \& Sinclair } 1986 \text { - } \\
\text { NZGA Vol. } 47\end{array}$ \\
\hline No tillage and direct drilling & $\begin{array}{l}\text { Introduction of productive } \\
\text { cultivars into old pasture }\end{array}$ & Ritchie 1986 - NZGA Vol. 47 \\
\hline $\begin{array}{l}\text { Grasslands Kopu white } \\
\text { clover }\end{array}$ & $\begin{array}{l}\text { Large leaved cultivar for } \\
\text { intensive lowland pastures }\end{array}$ & $\begin{array}{l}\text { van den Bosch et al. } 1986 \text { - } \\
\text { NZGA Vol. } 47\end{array}$ \\
\hline Browse shrubs & $\begin{array}{l}\text { Vegetation for low producing } \\
\text { sunny faces in the high country }\end{array}$ & $\begin{array}{l}\text { Wills et al. } 1987 \text { - NZGA Vol. } \\
48\end{array}$ \\
\hline Tagasaste & $\begin{array}{l}\text { Browse shrub for dryland } \\
\text { regions }\end{array}$ & $\begin{array}{l}\text { Townsend \& Radcliffe } 1987 \text { - } \\
\text { NZGA Vol. } 48\end{array}$ \\
\hline $\begin{array}{l}\text { Caucasian and Zigzag } \\
\text { clovers }\end{array}$ & $\begin{array}{l}\text { Persistent clovers in grazed } \\
\text { swards }\end{array}$ & $\begin{array}{l}\text { Daly \& Mason } 1987 \text { - NZGA } \\
\text { Vol. } 48\end{array}$ \\
\hline Yatsyn 1 & $\begin{array}{l}\text { High yielding endophyte } \\
\text { containing ryegrass cultivar }\end{array}$ & Kerr 1987 - NZGA Vol. 48 \\
\hline Lotus corniculatus & $\begin{array}{l}\text { Legume for South Island tussock } \\
\text { country }\end{array}$ & $\begin{array}{l}\text { Widdup et al. } 1987 \text { - NZGA } \\
\text { Vol. } 48\end{array}$ \\
\hline $\begin{array}{l}\text { Off farm winter grazing for } \\
\text { dairy farming }\end{array}$ & $\begin{array}{l}\text { Strategy for bridging the winter } \\
\text { feed gap }\end{array}$ & Wilson 1988 - NZGA Vol. 49 \\
\hline Microcomputers & $\begin{array}{l}\text { Pasture growth predictions to aid } \\
\text { management decisions }\end{array}$ & Baars 1988 - NZGA Vol. 49 \\
\hline $\begin{array}{l}\text { Genetic engineering of } \\
\text { animals, plants and microbes }\end{array}$ & $\begin{array}{l}\text { Potential for improved growth } \\
\text { rates and adaptation }\end{array}$ & $\begin{array}{l}\text { Forrest \& Broad 1988; White } \\
\text { 1988; Davis et al. } 1988 \text { - } \\
\text { NZGA Vol. } 49\end{array}$ \\
\hline Grasslands Puna chicory & $\begin{array}{l}\text { High quality forage giving high } \\
\text { animal growth rates }\end{array}$ & $\begin{array}{l}\text { Fraser et al. } 1988 \text { - NZGA Vol. } \\
49\end{array}$ \\
\hline $\begin{array}{l}\text { Grasslands Matua prairie } \\
\text { grass }\end{array}$ & $\begin{array}{l}\text { Grass for drier summers and } \\
\text { cooler winters }\end{array}$ & $\begin{array}{l}\text { Ridler et al. } 1988 \text { - NZGA Vol. } \\
49\end{array}$ \\
\hline $\begin{array}{l}\text { Annual growth cycle of } \\
\text { white clover plants } \\
\text { understood }\end{array}$ & $\begin{array}{l}\text { Assisting with grazing strategies } \\
\text { to enhance clover production } \\
\text { and persistence }\end{array}$ & $\begin{array}{l}\text { Hay et al. } 1988 \text { - NZGA Vol. } \\
49\end{array}$ \\
\hline Pasture probe & $\begin{array}{l}\text { Improved accuracy in measuring } \\
\text { pasture mass }\end{array}$ & $\begin{array}{l}\text { L'Huillier \& Thomson } 1988 \text { - } \\
\text { NZGA Vol. } 49\end{array}$ \\
\hline $\begin{array}{l}\text { Assessment of pasture } \\
\text { utilisation }\end{array}$ & $\begin{array}{l}\text { Framework for analysing } \\
\text { differences in productivity }\end{array}$ & $\begin{array}{l}\text { Brookes \& Holmes } 1988 \text { - } \\
\text { NZGA Vol. } 49\end{array}$ \\
\hline $\begin{array}{l}\text { Controlled release Se } \\
\text { granules }\end{array}$ & $\begin{array}{l}\text { Reduced incidence of Se } \\
\text { deficiency of sheep }\end{array}$ & $\begin{array}{l}\text { Watkinson } 1989 \text { - NZGA Vol. } \\
50\end{array}$ \\
\hline $\begin{array}{l}\mathrm{NaCl} \text { applications to Waikato } \\
\text { soils }\end{array}$ & Improved Na nutrition of cows & $\begin{array}{l}\text { O’Connor et al. } 1989 \text { - NZGA } \\
\text { Vol. } 50\end{array}$ \\
\hline $\begin{array}{l}\text { Tiller life cycle dynamics of } \\
\text { ryegrass }\end{array}$ & $\begin{array}{l}\text { Understanding ryegrass renewal } \\
\text { and implications for } \\
\text { management }\end{array}$ & $\begin{array}{l}\text { Matthew et al. } 1989 \text { - NZGA } \\
\text { Vol. } 50\end{array}$ \\
\hline
\end{tabular}




\begin{tabular}{|c|c|c|}
\hline Technology/advance & Impact/significance & Date - NZGA Proceedings \\
\hline Corvette annual ryegrass & $\begin{array}{l}\text { Able to co-exist with perennial } \\
\text { ryegrass in Northland }\end{array}$ & $\begin{array}{l}\text { Percival et al. } 1989 \text { - NZGA } \\
\text { Vol. } 50\end{array}$ \\
\hline $\begin{array}{l}\text { Grasslands Moata tetraploid } \\
\text { annual ryegrass }\end{array}$ & $\begin{array}{l}\text { Improved lamb growth in } \\
\text { Southland }\end{array}$ & $\begin{array}{l}\text { Hickey \& Baxter } 1989 \text { - NZGA } \\
\text { Vol. } 50\end{array}$ \\
\hline $\begin{array}{l}\text { Herbicide use before } \\
\text { oversowing }\end{array}$ & $\begin{array}{l}\text { Improved establishment of } \\
\text { oversown species }\end{array}$ & $\begin{array}{l}\text { Frengley \& Andersen } 1989 \text { - } \\
\text { NZGA Vol. } 50\end{array}$ \\
\hline $\begin{array}{l}\text { Grasslands Demand white } \\
\text { clover }\end{array}$ & $\begin{array}{l}\text { Improved white clover cultivar } \\
\text { bred for southern NZ }\end{array}$ & $\begin{array}{l}\text { Widdup et al. } 1989 \text { - NZGA } \\
\text { Vol. } 50\end{array}$ \\
\hline Grasslands Maru phalaris & $\begin{array}{l}\text { Increased flexibility and } \\
\text { improved production in hill } \\
\text { country }\end{array}$ & $\begin{array}{l}\text { Stevens et al. } 1989 \text { - NZGA } \\
\text { Vol. } 50\end{array}$ \\
\hline $\begin{array}{l}\text { Effects of withholding } \\
\text { phosphate application on hill } \\
\text { country }\end{array}$ & $\begin{array}{l}\text { Decline in measured pasture } \\
\text { production. Slower regrowth } \\
\text { after grazing. Less white clover } \\
\text { and more weeds. Reduced } \\
\text { liveweight gains. Possible } \\
\text { strategy for periods of low } \\
\text { product price:fertiliser cost ratio. }\end{array}$ & $\begin{array}{l}\text { Gillingham et al. 1990; } \\
\text { Rowarth \& Gillingham 1990; } \\
\text { O’Connor et al. 1990; } \\
\text { Lambert et al. 1990; } \\
\text { Clark et al. } 1990 \text { - NZGA Vol. } \\
51\end{array}$ \\
\hline Reactive rock phosphate & $\begin{array}{l}\text { Cheaper effective phosphate } \\
\text { fertiliser }\end{array}$ & $\begin{array}{l}\text { Sinclair } 1990 \text { - NZGA Vol. } 51 \\
\text { Mackay } 1990 \text { - NZGA Vol. } 51 \\
\end{array}$ \\
\hline $\begin{array}{l}\text { Trees for shelter and erosion } \\
\text { control on hill country }\end{array}$ & $\begin{array}{l}\text { Soil conservation and improved } \\
\text { animal welfare }\end{array}$ & Sturrock 1990 - NZGA Vol. 51 \\
\hline $\begin{array}{l}\text { Phalaris and tall fescue for } \\
\text { grass grub and drought prone } \\
\text { parts of Taranaki }\end{array}$ & Improved pasture production & $\begin{array}{l}\text { Judd et al. } 1990 \text { - NZGA Vol. } \\
51\end{array}$ \\
\hline $\begin{array}{l}\text { Tannins reduce bloat and } \\
\text { increase nutritive value }\end{array}$ & $\begin{array}{l}\text { Increased meat and milk } \\
\text { production }\end{array}$ & $\begin{array}{l}\text { Waghorn et al. } 1990 \text { - NZGA } \\
\text { Vol. } 51\end{array}$ \\
\hline Off - farm wintering of cows & Improved profitability & $\begin{array}{l}\text { Morton \& Jensen } 1990 \text { - NZGA } \\
\text { Vol. } 52\end{array}$ \\
\hline $\begin{array}{l}\text { Effect of spacing density and } \\
\text { grazing on seed production } \\
\text { of grasses }\end{array}$ & $\begin{array}{l}\text { Process for maximising grass } \\
\text { seed production }\end{array}$ & Hare 1990 - GR\&PS Vol. 5 \\
\hline $\begin{array}{l}\text { Efficacy of herbicides and } \\
\text { fertilisers for seed production }\end{array}$ & $\begin{array}{l}\text { Best practice for use for grass } \\
\text { seed production }\end{array}$ & Rolston 1990 - GR\&PS Vol. 5 \\
\hline $\begin{array}{l}\text { Efficacy of fungicides for } \\
\text { seed production }\end{array}$ & $\begin{array}{l}\text { Best practice for use for grass } \\
\text { seed production }\end{array}$ & Falloon 1990 - GR\&PS Vol. 5 \\
\hline Grass seed crop management & $\begin{array}{l}\text { Best practice management for } \\
\text { grass seed crops }\end{array}$ & $\begin{array}{l}\text { Brown et al. 1990a,b,c,d; Brown } \\
\text { \& McIntosh 1990; Brown \& Lill } \\
1990 \text { - GR\&PS Vol. } 5\end{array}$ \\
\hline $\begin{array}{l}\text { Potential of nil lolitrem } \\
\text { endophytes is indicated }\end{array}$ & $\begin{array}{l}\text { No staggers on ryegrass with } \\
\text { endophyte that gives resistance } \\
\text { to Argentine stem weevil }\end{array}$ & $\begin{array}{l}\text { Fletcher et al. } 1990 \text { - NZGA } \\
\text { Vol. } 52\end{array}$ \\
\hline $\begin{array}{l}\text { Serratia entomophila to } \\
\text { control grass grub }\end{array}$ & Biological control option & Jackson 1990 - NZGA Vol. 52 \\
\hline Necton sulla & A high quality non-bloating feed & $\begin{array}{l}\text { Krishna et al. } 1990 \text { - NZGA } \\
\text { Vol. } 52\end{array}$ \\
\hline Mediterranean saltbush & $\begin{array}{l}\text { Forage shrub for South Island } \\
\text { dry hill country }\end{array}$ & $\begin{array}{l}\text { Wills et al. } 1990 \text { - NZGA Vol. } \\
52\end{array}$ \\
\hline Grasslands Pacific ryegrass & $\begin{array}{l}\text { Improved summer and winter } \\
\text { growth }\end{array}$ & $\begin{array}{l}\text { Pennell et al. } 1990 \text { - NZGA } \\
\text { Vol. } 52\end{array}$ \\
\hline StockPol & $\begin{array}{l}\text { Farm scale decision support } \\
\text { model to analyse long term } \\
\text { policy changes or short term }\end{array}$ & $\begin{array}{l}\text { Marshall et al. 1991- NZGA } \\
\text { Vol. } 53\end{array}$ \\
\hline
\end{tabular}




\begin{tabular}{|c|c|c|}
\hline Technology/advance & Impact/significance & Date - NZGA Proceedings \\
\hline & feed budgets & \\
\hline $\begin{array}{l}\text { Policies for breeding beef } \\
\text { cows to improve winter feed } \\
\text { conversion efficiency }\end{array}$ & $\begin{array}{l}\text { Aim for older rather than } \\
\text { younger herd age structures, use } \\
\text { breeds of bull with high growth } \\
\text { rate and high survival rate } \\
\text { progeny, and winter only } \\
\text { pregnant heifers and cows. }\end{array}$ & $\begin{array}{l}\text { McMillan \& McCall 1991- } \\
\text { NZGA Vol. } 53\end{array}$ \\
\hline Fertiliser index & $\begin{array}{l}\text { Predictive model for economic } \\
\text { use of fertiliser }\end{array}$ & $\begin{array}{l}\text { McCall \& Thorrold } 1991 \text { - } \\
\text { NZGA Vol. } 53\end{array}$ \\
\hline $\mathrm{N}$ leaching from urine spots & $\begin{array}{l}\text { Major source of } \mathrm{N} \text { for grass } \\
\text { growth and loss to the system }\end{array}$ & $\begin{array}{l}\text { Ruz-Jerez et al. } 1991 \text { - NZGA } \\
\text { Vol. } 53\end{array}$ \\
\hline Endosafe ryegrass & $\begin{array}{l}\text { Staggers free (zero lolitrem B) } \\
\text { endophyte giving protection } \\
\text { against Argentine stem weevil }\end{array}$ & $\begin{array}{l}\text { Fletcher et al. } 1991 \text { - NZGA } \\
\text { Vol. } 53\end{array}$ \\
\hline Herbal ley & $\begin{array}{l}\text { A specialist pasture providing } \\
\text { high quality feed in summer }\end{array}$ & $\begin{array}{l}\text { Ruz-Jerez et al. } 1991 \text { - NZGA } \\
\text { Vol. } 53\end{array}$ \\
\hline Yatsyn-1 ryegrass & $\begin{array}{l}\text { Recommended for environments } \\
\text { prone to summer dryness to } \\
\text { increase annual dry matter } \\
\text { production }\end{array}$ & $\begin{array}{l}\text { Hainsworth et al. } 1991 \text { - NZGA } \\
\text { Vol. } 53\end{array}$ \\
\hline Pastoral fallow & $\begin{array}{l}\text { Improved white clover vigour } \\
\text { and N-fixation }\end{array}$ & $\begin{array}{l}\text { MacKay et al. } 1991 \text { - NZGA } \\
\text { Vol. } 53\end{array}$ \\
\hline Group farm monitoring & Improved technology transfer & $\begin{array}{l}\text { Webby \& Sheath } 1991 \text { - NZGA } \\
\text { Vol. } 53\end{array}$ \\
\hline $\begin{array}{l}\text { Pathogenic fungi and } \\
\text { parasitic wasp }\end{array}$ & $\begin{array}{l}\text { Control options for Argentine } \\
\text { stem weevil }\end{array}$ & $\begin{array}{l}\text { Prestidge et al. } 1991 \text { - NZGA } \\
\text { Vol. } 53\end{array}$ \\
\hline Strip seeder & $\begin{array}{l}\text { For introducing grasses and } \\
\text { legumes into semi-arid and } \\
\text { montane environments }\end{array}$ & $\begin{array}{l}\text { Horrell et al. 1991; Lowther et } \\
\text { al. } 1991 \text { - NZGA Vol. } 53\end{array}$ \\
\hline $\begin{array}{l}\text { Grazing management system } \\
\text { to minimise effect of } \\
\text { parasitic nematodes }\end{array}$ & $\begin{array}{l}\text { Improved lamb health and live } \\
\text { weight gains }\end{array}$ & $\begin{array}{l}\text { Thomson \& Power } 1991 \text { - } \\
\text { NZGA Vol. } 53\end{array}$ \\
\hline Deferred grazing & $\begin{array}{l}\text { Non-mechanical method of } \\
\text { pasture conservation }\end{array}$ & $\begin{array}{l}\text { McCallum et al. } 1991 \text { - NZGA } \\
\text { Vol. } 53\end{array}$ \\
\hline $\begin{array}{l}\text { Larger leaved white clover } \\
\text { germplasm with high stolon } \\
\text { densities }\end{array}$ & $\begin{array}{l}\text { Improved clover contents and } \\
\text { yields }\end{array}$ & Caradus 1991 - NZGA Vol. 53 \\
\hline Ryegrass life cycle & $\begin{array}{l}\text { Understanding management } \\
\text { impacts on yield and survival }\end{array}$ & $\begin{array}{l}\text { Brock \& Thomas } 1991 \text { - NZGA } \\
\text { Vol. } 53\end{array}$ \\
\hline $\begin{array}{l}\text { Preferential feeding of thin } \\
\text { ewes }\end{array}$ & $\begin{array}{l}\text { Reduced range of liveweights at } \\
\text { mating }\end{array}$ & Morton 1992 - NZGA Vol. 54 \\
\hline $\begin{array}{l}\text { Increased inoculation rates } \\
\text { for Lotus corniculatus } \\
\text { rhizobium inoculation }\end{array}$ & Improved nodulation & $\begin{array}{l}\text { Patrick \& Lowther } 1992 \text { - } \\
\text { NZGA Vol. } 54\end{array}$ \\
\hline $\begin{array}{l}\text { Caucasian clover, hairy } \\
\text { canary clover, birdsfoot } \\
\text { trefoil, lucerne, crown vetch }\end{array}$ & $\begin{array}{l}\text { Legumes for drought prone } \\
\text { landscapes }\end{array}$ & $\begin{array}{l}\text { Woodman et al. } 1992 \text { - NZGA } \\
\text { Vol. } 54\end{array}$ \\
\hline $\begin{array}{l}\text { Liming type and intensity to } \\
\text { ameliorate soil acidification }\end{array}$ & $\begin{array}{l}\text { Differential impact on legumes } \\
\text { and grasses }\end{array}$ & Carran 1992 - NZGA Vol. 54 \\
\hline Coating grass seed & Improved establishment & $\begin{array}{l}\text { Scott et al. } 1992 \text { - NZGA Vol. } \\
54\end{array}$ \\
\hline $\begin{array}{l}\text { Vegetative propagation of } \\
\text { rhizomes to establish some }\end{array}$ & Improved establishment & $\begin{array}{l}\text { Scott \& Mason } 1992 \text { - NZGA } \\
\text { Vol. } 54\end{array}$ \\
\hline
\end{tabular}




\begin{tabular}{|c|c|c|}
\hline Technology/advance & Impact/significance & Date - NZGA Proceedings \\
\hline \multicolumn{3}{|l|}{$\begin{array}{l}\text { legume species in high } \\
\text { country }\end{array}$} \\
\hline Grasslands Kara cocksfoot & $\begin{array}{l}\text { Improved cocksfoot with high } \\
\text { feeding value }\end{array}$ & $\begin{array}{l}\text { Stevens et al. } 1992 \text { - NZGA } \\
\text { Vol. } 54\end{array}$ \\
\hline $\begin{array}{l}\text { Summer fallowing and } \\
\text { double glyphosate spraying } \\
\text { to establish lolitrem-free } \\
\text { ryegrasses }\end{array}$ & $\begin{array}{l}\text { Methodology to reduce wild- } \\
\text { type endophyte contamination in } \\
\text { novel endophyte sown swards }\end{array}$ & $\begin{array}{l}\text { Hume \& Lyons } 1992 \text { - NZGA } \\
\text { Vol. } 54\end{array}$ \\
\hline $\begin{array}{l}\text { Nil endophyte effect in } \\
\text { Southland }\end{array}$ & $\begin{array}{l}\text { Endophyte not required in } \\
\text { ryegrass sown in Southland }\end{array}$ & $\begin{array}{l}\text { Eerens et al. } 1992 \text { - NZGA Vol. } \\
54\end{array}$ \\
\hline $\begin{array}{l}\text { High water use efficiency of } \\
\text { Grasslands Hakari brome and } \\
\text { Grasslands Maru phalaris }\end{array}$ & $\begin{array}{l}\text { Species with improved water use } \\
\text { efficiency for dryland regions }\end{array}$ & $\begin{array}{l}\text { Parry et al. } 1992 \text { - NZGA Vol. } \\
54\end{array}$ \\
\hline $\begin{array}{l}\text { Winter treading detrimentally } \\
\text { affects soil macroporosity }\end{array}$ & $\begin{array}{l}\text { Reduced drainage and increased } \\
\text { soil structural damage }\end{array}$ & $\begin{array}{l}\text { Greenwood \& McNamara } 1992 \\
\text { - NZGA Vol. } 54\end{array}$ \\
\hline $\begin{array}{l}\text { Once bred heifer and exotic } \mathrm{x} \\
\text { bull beef breeding }\end{array}$ & $\begin{array}{l}\text { Improved returns compared to } \\
\text { traditional beef breeding policies }\end{array}$ & $\begin{array}{l}\text { Morris et al. } 1992 \text { - NZGA Vol. } \\
54\end{array}$ \\
\hline $\begin{array}{l}\text { Tall fescue with clover and } \\
\text { chicory for feeding deer }\end{array}$ & $\begin{array}{l}\text { Improved carrying capacity } \\
\text { compared with ryegrass }\end{array}$ & $\begin{array}{l}\text { Stevens et al. } 1992 \text { - NZGA } \\
\text { Vol. } 54\end{array}$ \\
\hline $\begin{array}{l}\text { 'Longlife' phosphatic } \\
\text { fertiliser }\end{array}$ & $\begin{array}{l}\text { Suitable for use where } \\
\text { conditions are appropriate for } \\
\text { reactive phosphate rock use }\end{array}$ & $\begin{array}{l}\text { Ledgard et al. } 1992 \text { - NZGA } \\
\text { Vol. } 54\end{array}$ \\
\hline $\begin{array}{l}\text { Different } \mathrm{S} \text { oxidation rates on } \\
\text { sunny and shady faces }\end{array}$ & $\begin{array}{l}\text { Finer particle size of } \mathrm{S} \text { fertiliser } \\
\text { required on shady faces }\end{array}$ & $\begin{array}{l}\text { Boswell et al. } 1992 \text { - NZGA } \\
\text { Vol. } 54\end{array}$ \\
\hline $\begin{array}{l}\text { Frequency of phosphatic } \\
\text { fertiliser application on } \\
\text { developed pastures }\end{array}$ & Flexibility in rate of application & $\begin{array}{l}\text { Risk et al. } 1992 \text { - NZGA Vol. } \\
54\end{array}$ \\
\hline $\begin{array}{l}\text { Immobilisation of } \mathrm{P} \text { as } \\
\text { organic } \mathrm{P} \text { reduced } \\
\text { availability of inorganic } \mathrm{P} \text { for } \\
\text { plant use }\end{array}$ & Reduce plant available $\mathrm{P}$ & Perrott 1992 - NZGA Vol. 54 \\
\hline $\begin{array}{l}\text { Fertiliser requirements of } \\
\text { lucerne cut for hay }\end{array}$ & Maximising yields of lucerne & $\begin{array}{l}\text { Risk \& Smith } 1992 \text { - NZGA } \\
\text { Vol. } 54\end{array}$ \\
\hline $\begin{array}{l}\text { Undersowing to renovate } \\
\text { pugged pastures }\end{array}$ & $\begin{array}{l}\text { Improved pasture recovery from } \\
\text { damage }\end{array}$ & $\begin{array}{l}\text { Johnson et al. } 1993 \text { - NZGA } \\
\text { Vol. } 55\end{array}$ \\
\hline Lax spring grazing & $\begin{array}{l}\text { Increased grass tiller appearance } \\
\text { rate }\end{array}$ & $\begin{array}{l}\text { Hernandez-Garay et al. } 1993 \text { - } \\
\text { NZGA Vol. } 55\end{array}$ \\
\hline Timothy & Forage of high feeding value & $\begin{array}{l}\text { Stevens et al. } 1993 \text { - NZGA } \\
\text { Vol. } 55\end{array}$ \\
\hline $\begin{array}{l}\text { Summer fallowing to } \\
\text { establish ryegrass and tall } \\
\text { fescue in dryland } \\
\text { environments }\end{array}$ & Improved sward establishment & $\begin{array}{l}\text { Hume \& Lyons } 1993 \text { - NZGA } \\
\text { Vol. } 55\end{array}$ \\
\hline $\begin{array}{l}\text { Association of lamb } \\
\text { parasitism with species of } \\
\text { grass }\end{array}$ & $\begin{array}{l}\text { Higher rates of clinical } \\
\text { parasitism on browntop and } \\
\text { fescue than ryegrass and } \\
\text { Yorkshire fog }\end{array}$ & $\begin{array}{l}\text { Niezen et al. } 1993 \text { - NZGA Vol. } \\
55\end{array}$ \\
\hline Indicator paddocks & $\begin{array}{l}\text { Using a small sample of } \\
\text { paddocks to provide average } \\
\text { pasture cover estimates for } \\
\text { management decisions }\end{array}$ & $\begin{array}{l}\text { De Freitas et al. } 1993 \text { - NZGA } \\
\text { Vol. } 55\end{array}$ \\
\hline $\begin{array}{l}\text { Establishment protcol for } \\
\text { chicory }\end{array}$ & $\begin{array}{l}\text { Improved establishment of } \\
\text { chicory }\end{array}$ & $\begin{array}{l}\text { Moloney \& Milne } 1993 \text { - NZGA } \\
\text { Vol. } 55\end{array}$ \\
\hline
\end{tabular}




\begin{tabular}{|c|c|c|}
\hline Technology/advance & Impact/significance & Date - NZGA Proceedings \\
\hline $\begin{array}{l}\text { Zero grazing and use of } \\
\text { clovers and lotus to re- } \\
\text { vegetate slips }\end{array}$ & Protocol for re-vegetating slips & $\begin{array}{l}\text { Lambert et al. 1993; } \\
\text { Quilter } \text { et al. } 1993 \text { - NZGA Vol. } \\
55\end{array}$ \\
\hline FarmTracker & $\begin{array}{l}\text { Routines for setting stock, } \\
\text { paddock and feed targets }\end{array}$ & Butler 1993 - NZGA Vol. 55 \\
\hline UDDER & $\begin{array}{l}\text { Improves on-farm decision } \\
\text { making through modelling grass } \\
\text { growth and animal performance }\end{array}$ & $\begin{array}{l}\text { Lewis \& Garrity } 1993 \text { - NZGA } \\
\text { Vol. } 55\end{array}$ \\
\hline Monitor Farms & $\begin{array}{l}\text { Improved on-farm performance } \\
\text { through adoption of new } \\
\text { technologies and knowledge }\end{array}$ & $\begin{array}{l}\text { Rhodes \& Aspin } 1993 \text { - NZGA } \\
\text { Vol. } 55\end{array}$ \\
\hline COWPLAN and EWEPLAN & Feed budget models & $\begin{array}{l}\text { Brookes et al. } 1993 \text { - NZGA } \\
\text { Vol. } 55\end{array}$ \\
\hline Dryland pasture species & $\begin{array}{l}\text { Improved establishment of } \\
\text { pastures in dryland areas }\end{array}$ & $\begin{array}{l}\text { Milne et al. 1993; Korte \& } \\
\text { Rhodes } 1993 \text { - NZGA Vol. } 55\end{array}$ \\
\hline $\begin{array}{l}\text { Diammonium phosphate } \\
\text { (DAP) }\end{array}$ & $\begin{array}{l}\text { Associated with high animal and } \\
\text { financial performance }\end{array}$ & $\begin{array}{l}\text { Morton et al. 1993; Daniell } \\
1993 \text { - NZGA Vol. } 55\end{array}$ \\
\hline Farm Improvement Club & $\begin{array}{l}\text { Farmer improvement } \\
\text { programme }\end{array}$ & Baker 1993 - NZGA Vol. 55 \\
\hline $\begin{array}{l}\text { Late flowering subterranean } \\
\text { clover }\end{array}$ & $\begin{array}{l}\text { For improved regeneration in } \\
\text { wetter than normal seasons }\end{array}$ & $\begin{array}{l}\text { Smetham et al. } 1994 \text { - NZGA } \\
\text { Vol. } 56\end{array}$ \\
\hline $\begin{array}{l}\text { Strip seeding of Caucasian } \\
\text { clover }\end{array}$ & Improved establishment rate & $\begin{array}{l}\text { Moorhead et al. } 1994 \text { - NZGA } \\
\text { Vol. } 56\end{array}$ \\
\hline $\begin{array}{l}\text { Methodology for inoculation } \\
\text { of Caucasian clover }\end{array}$ & Improved nodulation & $\begin{array}{l}\text { Patrick et al. } 1994 \text { - NZGA Vol. } \\
56\end{array}$ \\
\hline G50 Alsike clover & $\begin{array}{l}\text { Improved yield and persistence } \\
\text { of Alsike clover for South Is. } \\
\text { high country }\end{array}$ & $\begin{array}{l}\text { Widdup \& Ryan } 1994 \text { - NZGA } \\
\text { Vol. } 56\end{array}$ \\
\hline $\begin{array}{l}\text { Complementary effects of } \\
\text { sowing phalaris and } \\
\text { cocksfoot }\end{array}$ & Improved yields & $\begin{array}{l}\text { Johnson et al. } 1994 \text { - NZGA } \\
\text { Vol. } 56\end{array}$ \\
\hline $\begin{array}{l}\text { Italian and brassicas as a } \\
\text { winter feed }\end{array}$ & $\begin{array}{l}\text { Improved hogget liveweight } \\
\text { gains }\end{array}$ & $\begin{array}{l}\text { Stevens et al. } 1994 \text { - NZGA } \\
\text { Vol. } 56\end{array}$ \\
\hline $\begin{array}{l}\text { Grasslands Advance tall } \\
\text { fescue }\end{array}$ & $\begin{array}{l}\text { Improved animal performance in } \\
\text { warm seasons }\end{array}$ & $\begin{array}{l}\text { Fraser \& Lyons } 1994 \text { - NZGA } \\
\text { Vol. } 56\end{array}$ \\
\hline $\begin{array}{l}\text { Grasslands Gala grazing } \\
\text { brome }\end{array}$ & $\begin{array}{l}\text { Desirable option for South Is } \\
\text { dryland environments }\end{array}$ & $\begin{array}{l}\text { Sutherland } 1994 \text { - NZGA Vol. } \\
56\end{array}$ \\
\hline $\begin{array}{l}\text { Double spraying and Massey } \\
\text { University bioblade drill }\end{array}$ & $\begin{array}{l}\text { Improved establishment of } \\
\text { grasses using direct drilling on } \\
\text { erosion prone dryland soils }\end{array}$ & $\begin{array}{l}\text { Fraser \& Hewson } 1994 \text { - NZGA } \\
\text { Vol. } 56\end{array}$ \\
\hline $\begin{array}{l}\text { Sclerotinia sclerotiorum } \\
\text { mycoherbicide }\end{array}$ & Control of Californian thistle & $\begin{array}{l}\text { Bourdot \& Harvey } 1994 \text { - } \\
\text { NZGA Vol. } 56\end{array}$ \\
\hline $\begin{array}{l}\text { Grazing management to } \\
\text { increase stolon density of } \\
\text { white clover }\end{array}$ & $\begin{array}{l}\text { Improved ability to withstand } \\
\text { drought }\end{array}$ & $\begin{array}{l}\text { Brock \& Kim } 1994 \text { - NZGA } \\
\text { Vol. } 56\end{array}$ \\
\hline $\begin{array}{l}\text { Parasitoid for Argentine stem } \\
\text { weevil }\end{array}$ & $\begin{array}{l}\text { Reduced impact of Argentine } \\
\text { stem weevil }\end{array}$ & $\begin{array}{l}\text { Goldson et al. } 1994 \text { - NZGA } \\
\text { Vol. } 56\end{array}$ \\
\hline $\begin{array}{l}\text { Impact of ergovaline from } \\
\text { grass endophytes on thermo- } \\
\text { regulation in lambs. }\end{array}$ & Increased heat stress & $\begin{array}{l}\text { Fletcher et al. } 1994 \text { - NZGA } \\
\text { Vol. } 56\end{array}$ \\
\hline $\begin{array}{l}\text { Risk management for tactical } \\
\mathrm{N} \text { applications }\end{array}$ & $\begin{array}{l}\text { Improved economics to the use } \\
\text { of N }\end{array}$ & $\begin{array}{l}\text { Parker et al. } 1994 \text { - NZGA Vol. } \\
56\end{array}$ \\
\hline Tall oat grass and Caucasian & Improved South Is. high country & Allan \& Keoghan 1994 - NZGA \\
\hline
\end{tabular}




\begin{tabular}{|c|c|c|}
\hline Technology/advance & Impact/significance & Date - NZGA Proceedings \\
\hline clover for high country & pastures & Vol. 56 \\
\hline $\begin{array}{l}\text { Winter feed crops for high } \\
\text { country }\end{array}$ & Improved marginal land use & $\begin{array}{l}\text { Maunsell \& Scott } 1994 \text { - NZGA } \\
\text { Vol. } 56\end{array}$ \\
\hline $\begin{array}{l}\text { Fertiliser borate FB48 to } \\
\text { control Hieracium }\end{array}$ & Control of Hieracium & Miller 1994 - NZGA Vol. 56 \\
\hline $\begin{array}{l}\text { Soil compaction to improve } \\
\text { irrigation efficiency }\end{array}$ & $\begin{array}{l}\text { Increased efficiency of irrigation } \\
\text { water use }\end{array}$ & $\begin{array}{l}\text { Paton \& Greenwood } 1994 \text { - } \\
\text { NZGA Vol. } 56\end{array}$ \\
\hline Dryland forage species & $\begin{array}{l}\text { Improved production on dryland } \\
\text { soils }\end{array}$ & $\begin{array}{l}\text { Hunter et al. } 1994 \text { - NZGA Vol. } \\
56\end{array}$ \\
\hline $\begin{array}{l}\text { Modifying stocking rates and } \\
\text { conservation policies with } \\
\text { use of high } \mathrm{N} \text { inputs }\end{array}$ & $\begin{array}{l}\text { Improved animal performance } \\
\text { on dairy farms with high } \mathrm{N} \text { use }\end{array}$ & $\begin{array}{l}\text { Harris et al. } 1994 \text { - NZGA Vol. } \\
56\end{array}$ \\
\hline $\begin{array}{l}\text { Process for establishment and } \\
\text { management of high country } \\
\text { pastures }\end{array}$ & $\begin{array}{l}\text { Improved understanding of } \\
\text { establishing and managing high } \\
\text { country pastures }\end{array}$ & $\begin{array}{l}\text { Scott et al. } 1995 \text { - GR\&PS Vol. } \\
4\end{array}$ \\
\hline $\begin{array}{l}\text { White clover cultivar change } \\
\text { seed production procedure }\end{array}$ & $\begin{array}{l}\text { 5-year break required for } \\
\text { successful cultivar change }\end{array}$ & $\begin{array}{l}\text { Clifford et al. 1996; Allen } 1996 \\
\text { - GR\&PS Vol. } 6\end{array}$ \\
\hline $\begin{array}{l}\text { Positioning of } 10 \text { current } \\
\text { white clover cultivars }\end{array}$ & $\begin{array}{l}\text { Description of agronomic } \\
\text { performance }\end{array}$ & $\begin{array}{l}\text { Caradus et al. } 1996 \text { - GR\&PS } \\
\text { Vol. } 6\end{array}$ \\
\hline $\begin{array}{l}\text { Managing grass/clover } \\
\text { associations }\end{array}$ & $\begin{array}{l}\text { Limitations and opportunities of } \\
\text { clover in grazed pastures }\end{array}$ & $\begin{array}{l}\text { Chapman et al. } 1996 \text { - GR\&PS } \\
\text { Vol. } 6\end{array}$ \\
\hline $\begin{array}{l}\text { Clonal growth process of } \\
\text { white clover }\end{array}$ & $\begin{array}{l}\text { Management strategies for } \\
\text { improved clover growth }\end{array}$ & $\begin{array}{l}\text { Brock \& Hay } 1996 \text { - GR\&PS } \\
\text { Vol. } 6\end{array}$ \\
\hline $\begin{array}{l}\text { Grassland Demand white } \\
\text { clover }\end{array}$ & Value to Southland sheep farmer & Gardyne 1996 - GR\&PS Vol. 6 \\
\hline Pastoral fallowing & $\begin{array}{l}\text { Increased white clover growth } \\
\text { post-fallow }\end{array}$ & Nie et al. 1996 - GR\&PS Vol. 6 \\
\hline $\begin{array}{l}\text { Principal environmental } \\
\text { impacts of } \mathrm{N} \text { identified }\end{array}$ & Risk of $\mathrm{N}$ fertiliser use & $\begin{array}{l}\text { Carran \& Clough } 1996 \text { - } \\
\text { GR\&PS Vol. } 6 \\
\end{array}$ \\
\hline $\begin{array}{l}\text { Cattle tend to graze white } \\
\text { clover from } 35 \text { to } 65 \% \text { of the } \\
\text { time depending on season }\end{array}$ & $\begin{array}{l}\text { Preference of cattle for white } \\
\text { clover }\end{array}$ & $\begin{array}{l}\text { Cosgrove et al. } 1996 \text { - GR\&PS } \\
\text { Vol. } 6\end{array}$ \\
\hline Mineral $\mathrm{N}$ fertiliser & $\begin{array}{l}\text { Moderate N fertiliser use (200- } \\
300 \mathrm{~kg} \mathrm{~N} / \mathrm{ha} / \mathrm{yr}) \text { give most } \\
\text { profitable outcome }\end{array}$ & Barr 1996 - GR\&PS Vol. 6 \\
\hline Mineral $\mathrm{N}$ and clover $\mathrm{N}$ & $\begin{array}{l}\text { Clover contents of } 30-40 \% \text { and } \\
\mathrm{N} \text { fertiliser rates of } 100-200 \mathrm{~kg} \\
\mathrm{~N} / \mathrm{ha} / \mathrm{yr} \text { recommended }\end{array}$ & $\begin{array}{l}\text { Clark \& Harris } 1996 \text { - GR\&PS } \\
\text { Vol. } 6\end{array}$ \\
\hline $\begin{array}{l}\text { White clover fixes } 4.5 \mathrm{~m} \\
\text { tonnes } \mathrm{N} \text { annually }\end{array}$ & $\begin{array}{l}\text { Most cost effective } \mathrm{N}-\text { need } \\
\text { only } 50 \mathrm{~kg} \text { fertiliser } \mathrm{N} / \mathrm{ha} / \mathrm{yr}\end{array}$ & Walker 1996 - GR\&PS Vol. 6 \\
\hline $\begin{array}{l}\text { Deferred grazing from } \\
\text { October to February }\end{array}$ & Improved clover content & $\begin{array}{l}\text { Watson et al. } 1996 \text { - GR\&PS } \\
\text { Vol. } 6\end{array}$ \\
\hline $\begin{array}{l}\text { Cow lifetime nutrition can } \\
\text { permanently affect calf live } \\
\text { weight }\end{array}$ & $\begin{array}{l}\text { Identification of nutrition } \\
\text { required in early life for } \\
\text { appropriate calf live weights }\end{array}$ & $\begin{array}{l}\text { Smeaton et al. } 1996 \text { - NZGA } \\
\text { Vol. } 57\end{array}$ \\
\hline BoVision & $\begin{array}{l}\text { Decision support system for beef } \\
\text { finishing }\end{array}$ & $\begin{array}{l}\text { Rollo et al. } 1996 \text { - NZGA Vol. } \\
57\end{array}$ \\
\hline $\begin{array}{l}\text { Yorkshire fog impact on } \\
\text { larval worm counts }\end{array}$ & $\begin{array}{l}\text { Lower worm counts for lambs } \\
\text { grazing Yorkshire fog }\end{array}$ & $\begin{array}{l}\text { Hodgson et al. } 1996 \text { - NZGA } \\
\text { Vol. } 57\end{array}$ \\
\hline $\begin{array}{l}\text { Importance of high stolon } \\
\text { density for drought survival } \\
\text { of white clover }\end{array}$ & $\begin{array}{l}\text { Identification of more drought } \\
\text { tolerant white clover cultivars }\end{array}$ & $\begin{array}{l}\text { Wang et al. } 1996 \text { - NZGA Vol. } \\
57\end{array}$ \\
\hline Setaria $-\mathrm{a} \mathrm{C}_{4}$ grass & Specialist pasture for use in & Boom \& Sheath 1996 - \\
\hline
\end{tabular}




\begin{tabular}{|c|c|c|}
\hline Technology/advance & Impact/significance & Date - NZGA Proceedings \\
\hline & drought conditions & Vol. 57 \\
\hline $\begin{array}{l}\text { Leaching of N significant at } \\
400 \mathrm{~kg} \mathrm{~N} / \mathrm{ha} \text { input }\end{array}$ & $\begin{array}{l}\text { Indication of potential issues at } \\
\text { high N inputs }\end{array}$ & $\begin{array}{l}\text { Ledgard et al. } 1996 \text { - NZGA } \\
\text { Vol. } 57\end{array}$ \\
\hline Seed bank surveys & $\begin{array}{l}\text { Method for assessing potential } \\
\text { changes in sward composition }\end{array}$ & Bell 1996 - NZGA Vol. 57 \\
\hline $\begin{array}{l}\text { MRDC-ANZ monitor farm } \\
\text { programme }\end{array}$ & $\begin{array}{l}\text { Improved farm productivity and } \\
\text { profitability }\end{array}$ & $\begin{array}{l}\text { Ussher et al. } 1996 \text { - NZGA Vol. } \\
57\end{array}$ \\
\hline Farm monitoring & $\begin{array}{l}\text { Improved production and } \\
\text { income }\end{array}$ & $\begin{array}{l}\text { Page et al. } 1996 \text { - NZGA Vol. } \\
57\end{array}$ \\
\hline $\begin{array}{l}\text { Lower nutritive value of } \\
\text { subtropical grasses }\end{array}$ & Decreased animal production & $\begin{array}{l}\text { Jackson et al. } 1996 \text { - NZGA } \\
\text { Vol. } 57\end{array}$ \\
\hline Split calving & Increased production and profit & Taylor 1996 - NZGA Vol. 57 \\
\hline Silage quality targets & $\begin{array}{l}\text { Most NZ silages do not achieve } \\
\text { targets }\end{array}$ & $\begin{array}{l}\text { Howse et al. } 1996 \text { - NZGA Vol. } \\
57\end{array}$ \\
\hline $\begin{array}{l}\text { Feed effects on milk } \\
\text { composition }\end{array}$ & $\begin{array}{l}\text { Manipulate milk composition by } \\
\text { changing pasture composition }\end{array}$ & $\begin{array}{l}\text { Johnson \& Thomson } 1996 \text { - } \\
\text { NZGA Vol. } 57\end{array}$ \\
\hline $\begin{array}{l}\text { Caucasian clover for irrigated } \\
\text { pastures in Canterbury }\end{array}$ & Improved sward quality & $\begin{array}{l}\text { Moss et al. } 1996 \text { - NZGA Vol. } \\
58\end{array}$ \\
\hline $\begin{array}{l}\text { Caucasian clover in dryland } \\
\text { dairying }\end{array}$ & $\begin{array}{l}\text { Once established a good legume } \\
\text { fro drought prone areas }\end{array}$ & $\begin{array}{l}\text { Watson et al. } 1996 \text { - NZGA } \\
\text { Vol. } 58\end{array}$ \\
\hline Nutrient budgets & Improved nutrient management & $\begin{array}{l}\text { O'Connor et al. } 1996 \text { - NZGA } \\
\text { Vol. } 58\end{array}$ \\
\hline $\begin{array}{l}\text { Fertiliser and seed mixture } \\
\text { recommendations for } \\
\text { conversions to dairy in } \\
\text { Canterbury }\end{array}$ & $\begin{array}{l}\mathrm{N} \text { and } \mathrm{P} \text { recommendations for } \\
\text { increased production }\end{array}$ & $\begin{array}{l}\text { Rowarth et al. } 1996 \text { - NZGA } \\
\text { Vol. } 58\end{array}$ \\
\hline Spreading red clovers & Improved persistence & $\begin{array}{l}\text { Hyslop et al. } 1996 \text { - NZGA } \\
\text { Vol. } 58\end{array}$ \\
\hline $\begin{array}{l}\text { Perennial lupin, tall oat grass } \\
\text { and cocksfoot }\end{array}$ & $\begin{array}{l}\text { Best suited species for drought } \\
\text { prone soils of the MacKenzie } \\
\text { Basin }\end{array}$ & $\begin{array}{l}\text { Woodman et al. } 1996 \text { - NZGA } \\
\text { Vol. } 58\end{array}$ \\
\hline G27 red clover & $\begin{array}{l}\text { Low formononetin red clover } \\
\text { that does not affect reproductive } \\
\text { performance of ewes }\end{array}$ & $\begin{array}{l}\text { Keogh et al. } 1996 \text { - NZGA Vol. } \\
58\end{array}$ \\
\hline Red clover & $\begin{array}{l}\text { Increased ewe milk production } \\
\text { and lamb growth rates compared } \\
\text { to ryegrass/white clover pastures }\end{array}$ & $\begin{array}{l}\text { Keogh \& Thomson } 1996- \\
\text { NZGA Vol. } 58\end{array}$ \\
\hline Selcote Ultra prills & $\begin{array}{l}\text { Supply of Se for wethers for } 24 \\
\text { months }\end{array}$ & $\begin{array}{l}\text { Metherell et al. } 1996 \text { - NZGA } \\
\text { Vol. } 58\end{array}$ \\
\hline $\begin{array}{l}\text { Decision support system for } \\
\text { predicting rainfall in semi } \\
\text { arid environments }\end{array}$ & $\begin{array}{l}\text { Assist with management } \\
\text { decisions }\end{array}$ & $\begin{array}{l}\text { Hutchinson } 1996 \text { - NZGA Vol. } \\
58\end{array}$ \\
\hline $\begin{array}{l}\text { Feed quality more important } \\
\text { than intake alone }\end{array}$ & Improved animal performance & $\begin{array}{l}\text { Fraser \& Rowarth } 1996 \text { - NZGA } \\
\text { Vol. } 58\end{array}$ \\
\hline Multi-species pastures & $\begin{array}{l}\text { Improved performance in } \\
\text { dryland conditions }\end{array}$ & $\begin{array}{l}\text { Daly et al. } 1996 \text { - NZGA Vol. } \\
58\end{array}$ \\
\hline $\begin{array}{l}\text { Pure chicory effects on } \\
\text { internal parasite populations }\end{array}$ & $\begin{array}{l}\text { Reduces gastro-intestinal } \\
\text { nematode larvae }\end{array}$ & $\begin{array}{l}\text { Knight et al. } 1996 \text { - NZGA Vol. } \\
58\end{array}$ \\
\hline Plantain & Component of mixed swards & Stewart 1996 - NZGA Vol. 58 \\
\hline Willow & Possible fodder tree & $\begin{array}{l}\text { Oppong et al. } 1996 \text { - NZGA } \\
\text { Vol. } 58\end{array}$ \\
\hline Maize & $\begin{array}{l}\text { Supplementary feed to overcome } \\
\text { feed limitations of pasture }\end{array}$ & $\begin{array}{l}\text { Penno et al. } 1996 \text { - NZGA Vol. } \\
58\end{array}$ \\
\hline
\end{tabular}




\begin{tabular}{|c|c|c|}
\hline Technology/advance & Impact/significance & Date - NZGA Proceedings \\
\hline Urea & $\begin{array}{l}\text { Most economical form of } \mathrm{N} \text { for } \\
\text { pasture growth }\end{array}$ & $\begin{array}{l}\text { Rogers \& Putt } 1997 \text { - NZGA } \\
\text { Vol. } 59\end{array}$ \\
\hline $\begin{array}{l}\text { Nitrate leaching similar for } \\
\text { mineral and biologically } \\
\text { fixed } \mathrm{N}\end{array}$ & $\begin{array}{l}\mathrm{N} \text { source has no impact on } \\
\text { amount of nitrate-N leached }\end{array}$ & $\begin{array}{l}\text { Sprosen et al. } 1997 \text { - NZGA } \\
\text { Vol. } 59\end{array}$ \\
\hline $\begin{array}{l}\text { Grasslands Challenge white } \\
\text { clover }\end{array}$ & $\begin{array}{l}\text { Large leaved clover with cool } \\
\text { season growth }\end{array}$ & $\begin{array}{l}\text { Cooper et al. } 1997 \text { - NZGA } \\
\text { Vol. } 59\end{array}$ \\
\hline $\begin{array}{l}\text { Pugging reduces feed } \\
\text { available and re-growth rates }\end{array}$ & $\begin{array}{l}\text { Management systems need to } \\
\text { reduce impact of pugging on wet } \\
\text { soils }\end{array}$ & $\begin{array}{l}\text { Sheath \& Boom } 1997 \text { - NZGA } \\
\text { Vol. } 59\end{array}$ \\
\hline Fertiliser S response model & $\begin{array}{l}\text { Calculation of effective } \mathrm{S} \\
\text { fertiliser rate }\end{array}$ & $\begin{array}{l}\text { Wheeler \& Thorrold } 1997 \text { - } \\
\text { NZGA Vol. } 59\end{array}$ \\
\hline $50 \%$ white clover content & $\begin{array}{l}\text { Target for maximum milk yield } \\
\text { from pasture }\end{array}$ & \begin{tabular}{|l} 
Harris et al. 1997 - NZGA Vol. \\
59
\end{tabular} \\
\hline Aries HD ryegrass & Improved lamb live weight gains & $\begin{array}{l}\text { Bluett et al. } 1997 \text { - NZGA Vol. } \\
59\end{array}$ \\
\hline $\begin{array}{l}\text { National Forage Variety } \\
\text { Trials }\end{array}$ & $\begin{array}{l}\text { Objective means of rating } \\
\text { cultivars }\end{array}$ & $\begin{array}{l}\text { Easton et al. } 1997 \text { - NZGA Vol. } \\
59\end{array}$ \\
\hline Financial risk model & $\begin{array}{l}\text { Provide insights into financial } \\
\text { consequences of pasture } \\
\text { development }\end{array}$ & $\begin{array}{l}\text { Martins et al. } 1997 \text { - NZGA } \\
\text { Vol. } 59\end{array}$ \\
\hline Grazing system model & Decision support model & $\begin{array}{l}\text { Barioni et al. } 1997 \text { - NZGA } \\
\text { Vol. } 59\end{array}$ \\
\hline $\begin{array}{l}\text { Model for determining } \mathrm{P} \text { and } \\
\mathrm{S} \text { inputs }\end{array}$ & $\begin{array}{l}\text { Decision support for fertiliser } \\
\text { recommendations }\end{array}$ & $\begin{array}{l}\text { Metherell et al. } 1997 \text { - NZGA } \\
\text { Vol. } 59\end{array}$ \\
\hline $\begin{array}{l}\text { Double spraying in autumn } \\
\text { to resow with novel } \\
\text { endophyte grasses }\end{array}$ & $\begin{array}{l}\text { Effective means of reducing } \\
\text { contamination from wild type } \\
\text { endophyte }\end{array}$ & $\begin{array}{l}\text { Van Vught \& Thom } 1997 \text { - } \\
\text { NZGA Vol. } 59\end{array}$ \\
\hline $\begin{array}{l}\text { Management package for } \\
\text { winter milk production }\end{array}$ & $\begin{array}{l}\text { Maximising profit from winter } \\
\text { milk production }\end{array}$ & \begin{tabular}{|l} 
Jones et al. 1997 - NZGA Vol. \\
59
\end{tabular} \\
\hline $\begin{array}{l}\mathrm{N} \text { fertiliser for increases } \\
\text { summer feed }\end{array}$ & More profitable milk production & $\begin{array}{l}\text { Shaw et al. } 1997 \text { - NZGA Vol. } \\
59\end{array}$ \\
\hline GrassView & $\begin{array}{l}\text { Computer programme that } \\
\text { demonstrates the form and } \\
\text { function of a grass plant }\end{array}$ & $\begin{array}{l}\text { Ashley et al. } 1997 \text { - NZGA Vol. } \\
59\end{array}$ \\
\hline $\begin{array}{l}\mathrm{AgFACT} \text { - pastoral } \\
\text { agriculture information base }\end{array}$ & Relevant information for farmers & $\begin{array}{l}\text { Ogle et al. } 1997 \text { - NZGA Vol. } \\
59\end{array}$ \\
\hline Tall fescue & $\begin{array}{l}\text { Recommended for dairying areas } \\
\text { where summer growth and } \\
\text { quality of ryegrass is low }\end{array}$ & $\begin{array}{l}\text { Milne et al. } 1997 \text { - NZGA Vol. } \\
59\end{array}$ \\
\hline Pine for agroforestry & Most profitable tree species & $\begin{array}{l}\text { Thorrold et al. } 1997 \text { - NZGA } \\
\text { Vol. } 59\end{array}$ \\
\hline $\begin{array}{l}\text { Conservation trees on hill } \\
\text { soils }\end{array}$ & $\begin{array}{l}\text { Reduced soil loss and improved } \\
\text { land stability }\end{array}$ & $\begin{array}{l}\text { Wall et al. } 1997 \text { - NZGA Vol. } \\
59\end{array}$ \\
\hline Lotus corniculatus & $\begin{array}{l}\text { Increased milk production and } \\
\text { protein yield per kg eaten }\end{array}$ & $\begin{array}{l}\text { Harris et al. } 1998 \text { - NZGA Vol. } \\
60\end{array}$ \\
\hline Sulla silage & High quality silage & $\begin{array}{l}\text { Niezen } \text { et al. } 1998 \text { - NZGA Vol. } \\
60\end{array}$ \\
\hline $\begin{array}{l}\text { N \& P applications by aspect } \\
\text { on hill country }\end{array}$ & $\begin{array}{l}\text { Maximising production from } \\
\text { fertiliser inputs }\end{array}$ & $\begin{array}{l}\text { Gillingham et al. } 1998 \text { - NZGA } \\
\text { Vol. } 60\end{array}$ \\
\hline $\begin{array}{l}\text { High cattle to sheep ratio for } \\
\text { chemical free farming } \\
\text { systems }\end{array}$ & Parasite free pastures & $\begin{array}{l}\text { Mackay et al. } 1998 \text { - NZGA } \\
\text { Vol. } 60\end{array}$ \\
\hline
\end{tabular}




\begin{tabular}{|c|c|c|}
\hline Technology/advance & Impact/significance & Date - NZGA Proceedings \\
\hline Clover nutrient ratios & $\begin{array}{l}\text { Accurate indicator of nutrient } \\
\text { fertiliser needs }\end{array}$ & $\begin{array}{l}\text { Morton et al. } 1998 \text { - NZGA } \\
\text { Vol. } 60\end{array}$ \\
\hline $\begin{array}{l}\text { Modelling animal treading } \\
\text { effects on infiltration rate }\end{array}$ & $\begin{array}{l}\text { Impacts of soil compaction on } \\
\text { catchment water movement }\end{array}$ & $\begin{array}{l}\text { Tian et al. } 1998 \text { - NZGA Vol. } \\
60\end{array}$ \\
\hline $\begin{array}{l}\text { Forages with condensed } \\
\text { tannins }\end{array}$ & $\begin{array}{l}\text { Improved animal productive } \\
\text { performance }\end{array}$ & $\begin{array}{l}\text { Waghorn et al. } 1998 \text { - NZGA } \\
\text { Vol. } 60\end{array}$ \\
\hline S input into high country & Related to sheep performance & Scott 1998 - NZGA Vol. 60 \\
\hline $\begin{array}{l}\text { Annual herbage } \\
\text { accumulation rate }\end{array}$ & Best predictor of farm milk yield & $\begin{array}{l}\text { Barker et al. } 1998 \text { - NZGA Vol. } \\
60\end{array}$ \\
\hline $\begin{array}{l}\text { Chicory supplemented with } \\
\text { pasture }\end{array}$ & $\begin{array}{l}\text { High quality summer-autumn } \\
\text { crop for dairying }\end{array}$ & $\begin{array}{l}\text { Waugh et al. } 1998 \text { - NZGA } \\
\text { Vol. } 60\end{array}$ \\
\hline $\begin{array}{l}\text { Predictive relationship } \\
\text { between pasture } \mathrm{Cu} \text { and liver } \\
\mathrm{Cu} \text { concentrations }\end{array}$ & $\begin{array}{l}\text { Recommendations for } \mathrm{Cu} \\
\text { fertiliser inputs }\end{array}$ & $\begin{array}{l}\text { Knowles et al. } 1998 \text { - NZGA } \\
\text { Vol. } 60\end{array}$ \\
\hline $\begin{array}{l}\text { Effect of closure time and } \\
\text { post grazing residuals on } \\
\text { silage quality }\end{array}$ & Improved silage quality & $\begin{array}{l}\text { McGrath et al. } 1998 \text { - NZGA } \\
\text { Vol. } 60\end{array}$ \\
\hline $\begin{array}{l}\text { Tall fescue and chicory in } \\
\text { summer dry areas }\end{array}$ & $\begin{array}{l}\text { Production advantages in dry } \\
\text { years }\end{array}$ & $\begin{array}{l}\text { Rollo et al. } 1998 \text { - NZGA Vol. } \\
60\end{array}$ \\
\hline $\begin{array}{l}\text { Wheat grass for dryland } \\
\text { agriculture }\end{array}$ & $\begin{array}{l}\text { Potential for increased } \\
\text { production }\end{array}$ & $\begin{array}{l}\text { Wills et al. } 1998 \text { - NZGA Vol. } \\
60\end{array}$ \\
\hline Tagasaste & $\begin{array}{l}\text { Drought tolerant shrub/tree } \\
\text { legume }\end{array}$ & $\begin{array}{l}\text { Douglas et al. } 1998 \text { - NZGA } \\
\text { Vol. } 60\end{array}$ \\
\hline $\begin{array}{l}\text { Copper topdressing onto } \\
\text { pastures and copper capsules } \\
\text { elevated liver Cu levels at } \\
\text { slaughter }\end{array}$ & $\begin{array}{l}\text { Increased } \mathrm{Cu} \text { uptake by } \\
\text { ruminants }\end{array}$ & $\begin{array}{l}\text { West \& Sargison } 1998 \text { - NZGA } \\
\text { Vol. } 60\end{array}$ \\
\hline $\begin{array}{l}\text { Osmia coerulescens an } \\
\text { alternative pollinator for } \\
\text { forage legumes }\end{array}$ & $\begin{array}{l}\text { A bee that is resistant to varroa } \\
\text { mite }\end{array}$ & $\begin{array}{l}\text { Purves et al. } 1998 \text { - NZGA Vol. } \\
60\end{array}$ \\
\hline $\begin{array}{l}\text { Maintaining adequate pasture } \\
\text { allowance for dairy cows }\end{array}$ & $\begin{array}{l}\text { Positive impact on milk yield } \\
\text { and processing for cheese }\end{array}$ & $\begin{array}{l}\text { Auldist et al. } 1998 \text { - NZGA } \\
\text { Vol. } 60\end{array}$ \\
\hline $\begin{array}{l}\text { Restricting beef cows for } \\
\text { first } 65 \text { days of lactation }\end{array}$ & $\begin{array}{l}\text { Better integration of beef and } \\
\text { sheep breeding operations }\end{array}$ & $\begin{array}{l}\text { Peachey \& Morris } 1998 \text { - NZGA } \\
\text { Vol. } 60\end{array}$ \\
\hline Ryegrass endophytes & Protection against insect pests & Easton 1999 - GR\&PS Vol. 7 \\
\hline Endophyte toxicoses & $\begin{array}{l}\text { Adverse effects on animal health } \\
\text { and production }\end{array}$ & $\begin{array}{l}\text { Fletcher et al. 1999; Watson et } \\
\text { al. } 1999 \text { - GR\&PS Vol. } 7\end{array}$ \\
\hline $\begin{array}{l}\text { Animal genetic component to } \\
\text { ryegrass staggers }\end{array}$ & $\begin{array}{l}\text { Potential for selecting for } \\
\text { tolerance to ryegrass staggers }\end{array}$ & $\begin{array}{l}\text { Morris et al. } 1999 \text { - GR\&PS } \\
\text { Vol. } 7\end{array}$ \\
\hline $\begin{array}{l}\text { Negative correlation between } \\
\text { ergovaline containing } \\
\text { pastures and milksolids } \\
\text { production in Northland }\end{array}$ & $\begin{array}{l}\text { Need to use low ergovaline } \\
\text { producing endophytes in humid } \\
\text { environments }\end{array}$ & $\begin{array}{l}\text { Blackwell \& Keogh } 1999 \text { - } \\
\text { GR\&PS Vol. } 7\end{array}$ \\
\hline $\begin{array}{l}\text { Chemical complexity of } \\
\text { endophyte metabolites }\end{array}$ & $\begin{array}{l}\text { Requirement to consider more } \\
\text { than just lolitrem, peramine and } \\
\text { ergovaline for biological activity } \\
\text { from endophytes }\end{array}$ & $\begin{array}{l}\text { Lane 1999; Lane et al. } 1999 \text { - } \\
\text { GR\&PS Vol. } 7\end{array}$ \\
\hline $\begin{array}{l}\text { Identification and } \\
\text { inoculation of endophytes } \\
\text { that reduce/eliminate grazing } \\
\text { animal toxicoses }\end{array}$ & $\begin{array}{l}\text { Use of these endophytes in } \\
\text { pastoral agriculture }\end{array}$ & $\begin{array}{l}\text { Tapper \& Latch 1999; Fletcher } \\
1999 \text { - GR\&PS Vol. } 7\end{array}$ \\
\hline $\begin{array}{l}\text { Insect resistances associated } \\
\text { with various endophyte }\end{array}$ & Toxin free endophytes identified & $\begin{array}{l}\text { Popay et al. } 1999 \text { - GR\&PS Vol. } \\
7\end{array}$ \\
\hline
\end{tabular}




\begin{tabular}{|c|c|c|}
\hline Technology/advance & Impact/significance & Date - NZGA Proceedings \\
\hline \multicolumn{3}{|l|}{ strains } \\
\hline $\begin{array}{l}\text { Process for maintaining a } \\
\text { toxin free pasture }\end{array}$ & Reduced risk of animal toxicoses & Hume 1999 - GR\&PS Vol. 7 \\
\hline $\begin{array}{l}\text { Proposed commercialisation } \\
\text { of AR1 }\end{array}$ & $\begin{array}{l}\text { Reduced animal toxicoses and } \\
\text { persistent pastures }\end{array}$ & $\begin{array}{l}\text { Green \& McKenzie } 1999 \text { - } \\
\text { GR\&PS Vol. } 7\end{array}$ \\
\hline $\begin{array}{l}\text { Ryegrass seed and endophyte } \\
\text { can survive longer than } 12 \\
\text { months in soil }\end{array}$ & $\begin{array}{l}\text { Likely contamination of } \\
\text { endophyte free pastures with } \\
\text { wild type endophyte seedlings }\end{array}$ & $\begin{array}{l}\text { Hume et al. } 1999 \text { - GR\&PS Vol. } \\
7\end{array}$ \\
\hline $\begin{array}{l}\text { Wide spaced poplars on hill } \\
\text { country farms }\end{array}$ & Improved soil conservation & $\begin{array}{l}\text { McGregor et al. } 1999 \text { - NZGA } \\
\text { Vol. } 61\end{array}$ \\
\hline Pre-lamb shearing & Increased lamb survival at birth & $\begin{array}{l}\text { Morris et al. } 1999 \text { - NZGA Vol. } \\
61\end{array}$ \\
\hline Land Management Units & $\begin{array}{l}\text { A means of evaluating } \\
\text { sustainability of land use } \\
\text { practices }\end{array}$ & $\begin{array}{l}\text { Rhodes et al. } 1999 \text { - NZGA } \\
\text { Vol. } 61\end{array}$ \\
\hline Se application to pastures & $\begin{array}{l}\text { Elevated blood Se levels in } \\
\text { sheep }\end{array}$ & $\begin{array}{l}\text { Moorhouse et al. } 1999 \text { - NZGA } \\
\text { Vol. } 61\end{array}$ \\
\hline Tannin containing forages & $\begin{array}{l}\text { Reduced development of } \\
\text { parasitic nematodes in sheep }\end{array}$ & $\begin{array}{l}\text { Molan et al. } 1999 \text { - NZGA Vol. } \\
61\end{array}$ \\
\hline $\begin{array}{l}\text { Identification of factors } \\
\text { causing dags }\end{array}$ & Reduced incidence of dags & $\begin{array}{l}\text { Waghorn et al. } 1999 \text { - NZGA } \\
\text { Vol. } 61\end{array}$ \\
\hline $\begin{array}{l}\text { Quality pasture species for } \\
\text { dryland }\end{array}$ & Improved animal performance & $\begin{array}{l}\text { Fraser et al. } 1999 \text { - NZGA Vol. } \\
61\end{array}$ \\
\hline $\begin{array}{l}\text { Vegetatively reproduced red } \\
\text { clovers }\end{array}$ & $\begin{array}{l}\text { Improved persistency of red } \\
\text { clover }\end{array}$ & $\begin{array}{l}\text { Hyslop et al. } 1999 \text { - NZGA } \\
\text { Vol. } 61\end{array}$ \\
\hline $\begin{array}{l}\text { Lotus corniculatus grazing } \\
\text { for sheep }\end{array}$ & Improved ovulation rate in ewes & $\begin{array}{l}\text { Barry et al. } 1999 \text { - NZGA Vol. } \\
61\end{array}$ \\
\hline $\begin{array}{l}\text { Reducing dags to reduce } \\
\text { incidence of fly strike and } \\
\text { lice in sheep }\end{array}$ & Improved animal performance & $\begin{array}{l}\text { Cole \& Heath } 1999 \text { - NZGA } \\
\text { Vol. } 61\end{array}$ \\
\hline $\begin{array}{l}\text { OVERSEER nutrient budget } \\
\text { model }\end{array}$ & $\begin{array}{l}\text { Estimates inputs, outputs and } \\
\text { balances N,P, K and S }\end{array}$ & $\begin{array}{l}\text { Ledgard et al. } 1999 \text { - NZGA } \\
\text { Vol. } 61\end{array}$ \\
\hline $\begin{array}{l}\text { NIRS for predicting feed } \\
\text { composition }\end{array}$ & Improved feed ration balancing & $\begin{array}{l}\text { Corson et al. } 1999 \text { - NZGA } \\
\text { Vol. } 61\end{array}$ \\
\hline $\begin{array}{l}\text { Geographical positioning } \\
\text { system (GPS) and } \\
\text { Geographic information } \\
\text { system (GIS) }\end{array}$ & $\begin{array}{l}\text { Increased accuracy of fertiliser } \\
\text { topdressing application }\end{array}$ & $\begin{array}{l}\text { Gillingham et al. } 1999 \text { - NZGA } \\
\text { Vol. } 61\end{array}$ \\
\hline Precision Farming & Increased profit & Yule 1999 - NZGA Vol. 61 \\
\hline Shelterbelts & $\begin{array}{l}\text { Diversification and possible } \\
\text { animal welfare improvements }\end{array}$ & $\begin{array}{l}\text { Hawke et al. } 1999 \text { - NZGA Vol. } \\
61\end{array}$ \\
\hline Mowing or topping pasture & $\begin{array}{l}\text { Improved summer milk yields } \\
\text { but negligible annual benefits }\end{array}$ & $\begin{array}{l}\text { Kolver et al. } 1999 \text { - NZGA Vol. } \\
61\end{array}$ \\
\hline $\begin{array}{l}\text { Spreadmark standards for } \\
\text { fertiliser evenness }\end{array}$ & $\begin{array}{l}\text { Improved effectiveness of } \\
\text { fertiliser application }\end{array}$ & $\begin{array}{l}\text { Horrell et al. } 1999 \text { - NZGA } \\
\text { Vol. } 61\end{array}$ \\
\hline $\begin{array}{l}\text { Interaction of soil Mn status } \\
\text { and Co availability }\end{array}$ & $\begin{array}{l}\text { High Mn levels reduced Co } \\
\text { availability }\end{array}$ & $\begin{array}{l}\text { Zheng et al. } 1999 \text { - NZGA Vol. } \\
61\end{array}$ \\
\hline 109 forage cultivars & $\begin{array}{l}\text { Proprietary cultivars for NZ } \\
\text { farmers }\end{array}$ & $\begin{array}{l}\text { Charlton \& Stewart } 1999 \text { - } \\
\text { NZGA Vol } 61\end{array}$ \\
\hline National Climate Centre & Improved climate information & Daw 1999 - NZGA Vol. 61 \\
\hline $\begin{array}{l}\text { Collated list of pasture and } \\
\text { forage cultivars }\end{array}$ & $\begin{array}{l}\text { Assistance in identifying } \\
\text { appropriate seed mixtures }\end{array}$ & $\begin{array}{l}\text { Charlton \& Stewart } 2000 \text { - } \\
\text { GR\&PS Vol. } 8\end{array}$ \\
\hline
\end{tabular}




\begin{tabular}{|c|c|c|}
\hline Technology/advance & Impact/significance & Date - NZGA Proceedings \\
\hline $\begin{array}{l}\text { Once-a-day milk feeding } \\
\text { system }\end{array}$ & $\begin{array}{l}\text { Successful and cost effective } \\
\text { method of rearing calves }\end{array}$ & $\begin{array}{l}\text { Muir et al. } 2000 \text { - NZGA Vol. } \\
62\end{array}$ \\
\hline QuickFeed & $\begin{array}{l}\text { Predicts intake ad performance } \\
\text { of cattle and sheep on pasture }\end{array}$ & $\begin{array}{l}\text { Woodward et al. } 2000 \text { - NZGA } \\
\text { Vol. } 62\end{array}$ \\
\hline Strip seeder technique & $\begin{array}{l}\text { Improved establishment in } \\
\text { drought prone soils }\end{array}$ & $\begin{array}{l}\text { Wills \& Trainor } 2000 \text { - NZGA } \\
\text { Vol. } 62\end{array}$ \\
\hline Pasture resowing & Improved profitability & $\begin{array}{l}\text { Stevens et al. } 2000 \text { - NZGA } \\
\text { Vol. } 62\end{array}$ \\
\hline Caucasian clover & $\begin{array}{l}\text { More tolerant of drought than } \\
\text { white clover }\end{array}$ & $\begin{array}{l}\text { Black \& Lucas } 2000 \text { - NZGA } \\
\text { Vol. } 62\end{array}$ \\
\hline $\begin{array}{l}\text { Land application of dairy } \\
\text { effluent }\end{array}$ & $\begin{array}{l}\text { Growth responses similar to urea } \\
\text { at same } \mathrm{N} \text { input rates, but } \\
\text { increased } \mathrm{K} \text { concentrations in } \\
\text { pasture }\end{array}$ & $\begin{array}{l}\text { Roach et al. } 2000 \text { - NZGA Vol. } \\
62\end{array}$ \\
\hline $\begin{array}{l}\text { Denmark and Leura } \\
\text { subterranean clover }\end{array}$ & $\begin{array}{l}\text { Improved re-establishment and } \\
\text { late winter-spring growth }\end{array}$ & $\begin{array}{l}\text { Widdup \& Pennell } 2000 \text { - } \\
\text { NZGA Vol. } 62\end{array}$ \\
\hline $\begin{array}{l}\text { Low rates of glyphosate use } \\
\text { on pastures }\end{array}$ & $\begin{array}{l}\text { Improved pasture quality and } \\
\text { reduced weeds }\end{array}$ & $\begin{array}{l}\text { Casey et al. } 2000 \text { - NZGA Vol. } \\
62\end{array}$ \\
\hline $\begin{array}{l}\text { Single } \mathrm{N} \text { application in } \\
\text { March or August }\end{array}$ & $\begin{array}{l}\text { Increased pasture production in } \\
\text { Southland }\end{array}$ & $\begin{array}{l}\text { Smith et al. } 2000 \text { - NZGA Vol. } \\
62\end{array}$ \\
\hline Strategic destocking & $\begin{array}{l}\text { Reduced pugging and nitrate } \\
\text { leaching }\end{array}$ & $\begin{array}{l}\text { de Klein et al. } 2000 \text { - NZGA } \\
\text { Vol. } 62\end{array}$ \\
\hline AR1 endophyte & $\begin{array}{l}\text { Enhanced livestock production } \\
\text { and resistance to Argentine stem } \\
\text { weevil }\end{array}$ & $\begin{array}{l}\text { Easton et al. } 2001 \text { - NZGA Vol. } \\
63\end{array}$ \\
\hline TechnoGrazing & $\begin{array}{l}\text { Increased pasture utilisation and } \\
\text { profits }\end{array}$ & $\begin{array}{l}\text { Charlton \& Weir } 2001 \text { - NZGA } \\
\text { Vol. } 63\end{array}$ \\
\hline $\begin{array}{l}\text { Grasslands Tahora and Prop } \\
\text { white clovers }\end{array}$ & $\begin{array}{l}\text { Cultivars adapted to moist and } \\
\text { dry hill country }\end{array}$ & $\begin{array}{l}\text { Dodd et al. } 2001 \text { - NZGA Vol. } \\
63\end{array}$ \\
\hline $\begin{array}{l}\text { Grasslands Kopu II and } \\
\text { Crusader white clovers } \\
\end{array}$ & $\begin{array}{l}\text { Clover cultivars for national and } \\
\text { international markets }\end{array}$ & $\begin{array}{l}\text { Woodfield et al. } 2001 \text { - NZGA } \\
\text { Vol. } 63\end{array}$ \\
\hline Browse willows & Nutritive feed for cattle & $\begin{array}{l}\text { Kemp et al. } 2001 \text { - NZGA Vol. } \\
63\end{array}$ \\
\hline Low toxin endophytes & $\begin{array}{l}\text { Improved pasture quality and } \\
\text { increased milksolids production }\end{array}$ & $\begin{array}{l}\text { Keogh \& Blackwell } 2001 \text { - } \\
\text { NZGA Vol. } 63\end{array}$ \\
\hline Maize silage & $\begin{array}{l}\text { Cost effective supplementary } \\
\text { feed }\end{array}$ & $\begin{array}{l}\text { Densley et al. } 2001 \text { - NZGA } \\
\text { Vol. } 63\end{array}$ \\
\hline $\begin{array}{l}\text { Protocols for low chemical } \\
\text { farming systems }\end{array}$ & Organic farming options & $\begin{array}{l}\text { Mackay et al. } 2001 \text { - NZGA } \\
\text { Vol. } 63\end{array}$ \\
\hline Tannins in erect Dorycnium & $\begin{array}{l}\text { Disrupts the gastro-intestinal } \\
\text { parasite life cycle }\end{array}$ & $\begin{array}{l}\text { Waghorn \& Molan } 2001 \text { - } \\
\text { NZGA Vol. } 63\end{array}$ \\
\hline $\begin{array}{l}\text { Protocol for sowing novel } \\
\text { endophyte ryegrass }\end{array}$ & $\begin{array}{l}\text { Reduced contamination from } \\
\text { wild type endophyte ryegrass }\end{array}$ & $\begin{array}{l}\text { Bluett et al. } 2001 \text { - NZGA Vol. } \\
63\end{array}$ \\
\hline $\begin{array}{l}\text { Parasitoid for Argentine stem } \\
\text { weevil }\end{array}$ & Biological control option & $\begin{array}{l}\text { McNeill et al. } 2001 \text { - NZGA } \\
\text { Vol. } 63\end{array}$ \\
\hline Clover content & $\begin{array}{l}\text { Trends in milksolids production } \\
\text { follow clover content }\end{array}$ & $\begin{array}{l}\text { Thom et al. } 2001 \text { - NZGA Vol. } \\
63\end{array}$ \\
\hline $\begin{array}{l}\text { Pasture utilisation efficiency } \\
\text { increases with LWT/t DM }\end{array}$ & $\begin{array}{l}\text { Optimum economic farm surplus } \\
\text { occurs at less than maximum } \\
\text { feed efficiency }\end{array}$ & $\begin{array}{l}\text { MacDonald et al. } 2001 \text { - NZGA } \\
\text { Vol. } 63\end{array}$ \\
\hline $\begin{array}{l}\text { Targets for good maize silage } \\
\text { quality }\end{array}$ & Improved nutritive value & $\begin{array}{l}\text { Kolver et al. } 2001 \text { - NZGA Vol. } \\
63\end{array}$ \\
\hline Rising plate meter & Inexpensive tool to aid farm & Lile et al. 2001 - NZGA Vol. \\
\hline
\end{tabular}




\begin{tabular}{|c|c|c|}
\hline Technology/advance & Impact/significance & \begin{tabular}{|l} 
Date - NZGA Proceedings \\
\end{tabular} \\
\hline & monitoring and decision making & 63 \\
\hline $\begin{array}{l}\text { Standard calibration for } \\
\text { rising plate meter }\end{array}$ & $\begin{array}{l}\text { Improved reliability of pasture } \\
\text { mass measurement }\end{array}$ & $\begin{array}{l}\text { Thomson et al. } 2001 \text { - NZGA } \\
\text { Vol. } 63\end{array}$ \\
\hline Best practice calf rearing & Successful calf rearing & $\begin{array}{l}\text { Muir et al. } 2002 \text { - NZGA Vol. } \\
64\end{array}$ \\
\hline $\begin{array}{l}\text { Effect of breed and milking } \\
\text { frequency on milksolids } \\
\text { production and productivity }\end{array}$ & $\begin{array}{l}\text { Jersey cow better suited to once } \\
\text { a day milking }\end{array}$ & $\begin{array}{l}\text { Tong et al. } 2002 \text { - NZGA Vol. } \\
64\end{array}$ \\
\hline $\begin{array}{l}\text { Automatic milking systems } \\
\text { (AMS) }\end{array}$ & $\begin{array}{l}\text { Potential indicated for using } \\
\text { AMS in extensive grazed } \\
\text { systems }\end{array}$ & $\begin{array}{l}\text { Jago \& Woolford } 2002 \text { - NZGA } \\
\text { Vol. } 64\end{array}$ \\
\hline Kuriwao Farm Action Group & $\begin{array}{l}\text { Faster progress and less costly } \\
\text { mistakes in uptake of knowledge } \\
\text { and technologies }\end{array}$ & $\begin{array}{l}\text { Cock et al. } 2002 \text { - NZGA Vol. } \\
64\end{array}$ \\
\hline $\begin{array}{l}\text { Close frequent grazing to } \\
\text { remove Californian thistle }\end{array}$ & Reduced thistle presence & $\begin{array}{l}\text { Mitchell et al. } 2002 \text { - NZGA } \\
\text { Vol. } 64\end{array}$ \\
\hline $\begin{array}{l}\text { Mycoherbicide - Sclerotinia } \\
\text { sclerotiorum }\end{array}$ & $\begin{array}{l}\text { Biological control of giant } \\
\text { buttercup }\end{array}$ & $\begin{array}{l}\text { Bourdot \& Lamoureaux } 2002 \text { - } \\
\text { NZGA Vol. } 64\end{array}$ \\
\hline Lotus silage & $\begin{array}{l}\text { Improved summer-autumn } \\
\text { milksolids }\end{array}$ & $\begin{array}{l}\text { Woodward et al. } 2002 \text { - NZGA } \\
\text { Vol. } 64\end{array}$ \\
\hline $\begin{array}{l}\text { Weekly estimates of pasture } \\
\text { growth rate }\end{array}$ & $\begin{array}{l}\text { Increased accuracy of monthly } \\
\text { growth rates }\end{array}$ & $\begin{array}{l}\text { Prewer et al. } 2002 \text { - NZGA Vol. } \\
64\end{array}$ \\
\hline $\begin{array}{l}2 \text { day spell for animals } \\
\text { grazing high endophyte } \\
\text { before moving to paddocks } \\
\text { with nil or novel endophyte }\end{array}$ & $\begin{array}{l}\text { Reduced contamination of nil } \\
\text { and novel endophyte swards }\end{array}$ & $\begin{array}{l}\text { Burggraaf \&Thom } 2002 \text { - } \\
\text { NZGA Vol. } 64\end{array}$ \\
\hline $\begin{array}{l}\text { High quality lamb specific } \\
\text { pasture }\end{array}$ & $\begin{array}{l}\text { Enhancing lamb growth rates } \\
\text { prior to weaning }\end{array}$ & $\begin{array}{l}\text { Moffat et al. } 2002 \text { - NZGA Vol. } \\
64\end{array}$ \\
\hline $\begin{array}{l}\text { Condition scoring of beef } \\
\text { cows }\end{array}$ & $\begin{array}{l}\text { Improved monitoring of feed } \\
\text { regimes }\end{array}$ & $\begin{array}{l}\text { Morris et al. } 2002 \text { - NZGA Vol. } \\
64\end{array}$ \\
\hline Sulla silage & $\begin{array}{l}\text { Increased digestion rate and } \\
\text { rumen clearance }\end{array}$ & $\begin{array}{l}\text { Chaves et al. } 2002 \text { - NZGA } \\
\text { Vol. } 64\end{array}$ \\
\hline Longer pasture residuals & Reduced weed problems & $\begin{array}{l}\text { Eerens et al. } 2002 \text { - NZGA Vol. } \\
64\end{array}$ \\
\hline Ragwort flee beetle & Biocontrol of ragwort & \begin{tabular}{|l|} 
Betteridge \& Costall 2002 - \\
NZGA Vol. 64 \\
\end{tabular} \\
\hline $\begin{array}{l}\text { Cereal silage and stand-off } \\
\text { pads }\end{array}$ & $\begin{array}{l}\text { Reduced greenhouse gas } \\
\text { emissions }\end{array}$ & $\begin{array}{l}\text { de Klein et al. } 2002 \text { - NZGA } \\
\text { Vol. } 64\end{array}$ \\
\hline Condensed tannin forages & Reduced methane production & $\begin{array}{l}\text { Waghorn et al. } 2002 \text { - NZGA } \\
\text { Vol. } 64\end{array}$ \\
\hline Whole crop cereals & South Is high quality feed option & \begin{tabular}{|l|} 
de Ruiter et al. 2002 - NZGA \\
Vol. 64
\end{tabular} \\
\hline $\mathrm{NaCl}$ use & Reduced Na deficiency & $\begin{array}{l}\text { Hawke et al. } 2002 \text { - NZGA Vol. } \\
64\end{array}$ \\
\hline $\begin{array}{l}\text { Updated list of pasture and } \\
\text { forage cultivars }\end{array}$ & $\begin{array}{l}\text { Assistance in identifying } \\
\text { appropriate seed mixtures }\end{array}$ & $\begin{array}{l}\text { Charlton \& Stewart } 2003 \text { - } \\
\text { GR\&PS Vol. } 82^{\text {nd }} \text { edition }\end{array}$ \\
\hline $\begin{array}{l}\text { Grazing behaviour of deer } \\
\text { related to pasture height and } \\
\text { mass }\end{array}$ & $\begin{array}{l}\text { Maximum levels of deer } \\
\text { production achieved at a pasture } \\
\text { height of } 8 \mathrm{~cm}\end{array}$ & $\begin{array}{l}\text { Nicol \& Barry } 2003 \text { - GR\&PS } \\
\text { Vol. } 9\end{array}$ \\
\hline $\begin{array}{l}\text { Deer have salivary proteins } \\
\text { that bind condensed tannins }\end{array}$ & $\begin{array}{l}\text { Deer can consume forages with } \\
\text { high concentrations of } \\
\text { condensed tannins }\end{array}$ & $\begin{array}{l}\text { Hoskin et al. } 2003 \text { - GR\&PS } \\
\text { Vol. } 9\end{array}$ \\
\hline
\end{tabular}




\begin{tabular}{|c|c|c|}
\hline Technology/advance & Impact/significance & Date - NZGA Proceedings \\
\hline Fodder trees & $\begin{array}{l}\text { Fodder trees can provide useful } \\
\text { feed in drought }\end{array}$ & $\begin{array}{l}\text { Charlton et al. 2003; Olsen \& } \\
\text { Charlton 2003; Kemp et al. } \\
2003 \text { - GR\&PS Vol. } 10\end{array}$ \\
\hline $\begin{array}{l}\text { Poplar and willow feed } \\
\text { increase reproductive rate of } \\
\text { ewes }\end{array}$ & $\begin{array}{l}\text { Increased reproductive } \\
\text { performance }\end{array}$ & $\begin{array}{l}\text { McWilliam et al. 2003; } \\
\text { Orsborn et al. } 2003 \text { - GR\&PS } \\
\text { Vol. } 10\end{array}$ \\
\hline Tangoio tree willow & Tree clone for fodder production & $\begin{array}{l}\text { Douglas et al. } 2003 \text { - GR\&PS } \\
\text { Vol. } 10\end{array}$ \\
\hline Tree shelter & Increased animal production & $\begin{array}{l}\text { Hawke \& Dodd } 2003 \text { - GR\&PS } \\
\text { Vol. } 10\end{array}$ \\
\hline Farm Forestry Calculators & $\begin{array}{l}\text { Decision support system to assist } \\
\text { with farm forestry management }\end{array}$ & $\begin{array}{l}\text { Halliday \& Knowles } 2003 \text { - } \\
\text { GR\&PS Vol. } 10\end{array}$ \\
\hline Subterranean clover & Legume for dry hill country & $\begin{array}{l}\text { Smetham } 2003 \text { - GR\&PS Vol. } \\
11\end{array}$ \\
\hline Caucasian clover & $\begin{array}{l}\text { Legume with potential for } \\
\text { increased spring and summer } \\
\text { production }\end{array}$ & $\begin{array}{l}\text { Black et al. } 2003 \text { - GR\&PS Vol. } \\
11\end{array}$ \\
\hline Rooting depth of lucerne & $\begin{array}{l}\text { Access to more water during } \\
\text { summer/autumn }\end{array}$ & $\begin{array}{l}\text { Brown et al. } 2003 \text { - GR\&PS } \\
\text { Vol. } 11\end{array}$ \\
\hline Lotus corniculatus & $\begin{array}{l}\text { Potential as a specialist feed in } \\
\text { dryland environments }\end{array}$ & $\begin{array}{l}\text { Barry et al. 2003; } \\
\text { Ramirez-Restrepo et al. } 2003 \text { - } \\
\text { GR\&PS Vol. } 11\end{array}$ \\
\hline $\begin{array}{l}\text { Persian, balansa and } \\
\text { subterranean clovers }\end{array}$ & $\begin{array}{l}\text { Winter active legumes preferred } \\
\text { by hoggets }\end{array}$ & $\begin{array}{l}\text { Hyslop et al. } 2003 \text { - GR\&PS } \\
\text { Vol. } 11\end{array}$ \\
\hline $\begin{array}{l}\text { Grass suppression using the } \\
\text { herbicide Gallant }\end{array}$ & Improved legume content & $\begin{array}{l}\text { Hepp et al. } 2003 \text { - GR\&PS Vol. } \\
11\end{array}$ \\
\hline $\begin{array}{l}\text { Trifolium repens } \mathrm{x} T \text {. } \\
\text { ambiguum hybrid }\end{array}$ & $\begin{array}{l}\text { Potential for improved drought } \\
\text { tolerance }\end{array}$ & $\begin{array}{l}\text { Widdup et al. } 2003 \text { - GR\&PS } \\
\text { Vol. } 11\end{array}$ \\
\hline $\begin{array}{l}\text { Reduce grazing pressure on } \\
\text { subterranean clover during } \\
\text { flowering and seed } \\
\text { maturation }\end{array}$ & $\begin{array}{l}\text { Increased subterranean clover } \\
\text { seed production in grazed } \\
\text { pastures }\end{array}$ & $\begin{array}{l}\text { Smetham \& Dear } 2003 \text { - } \\
\text { GR\&PS Vol. } 11\end{array}$ \\
\hline $\begin{array}{l}\text { Lucerne provides extra } \\
\text { summer feed on North Is. hill } \\
\text { country }\end{array}$ & Improved lamb production & $\begin{array}{l}\text { McGowan et al. } 2003 \text { - GR\&PS } \\
\text { Vol. } 11\end{array}$ \\
\hline $\begin{array}{l}\text { Strategy for managing } \\
\text { lucerne }\end{array}$ & Improved lucerne growth & $\begin{array}{l}\text { Moot et al. } 2003 \text { - GR\&PS Vol. } \\
11\end{array}$ \\
\hline $\begin{array}{l}\text { Subterranean clover autumn } \\
\text { sward management }\end{array}$ & $\begin{array}{l}\text { Increased subterranean clover } \\
\text { yields }\end{array}$ & $\begin{array}{l}\text { Moot et al. } 2003 \text { - GR\&PS Vol. } \\
11\end{array}$ \\
\hline $\begin{array}{l}\text { Maximising pasture growth } \\
\text { and utilisation of all year } \\
\text { round grass farming }\end{array}$ & $\begin{array}{l}\text { Improved efficiency of bull beef } \\
\text { production }\end{array}$ & $\begin{array}{l}\text { Cosgrove et al. } 2003 \text { - NZGA } \\
\text { Vol. } 65\end{array}$ \\
\hline $\begin{array}{l}\text { High } \mathrm{N} \text { fertiliser inputs on } \\
\text { hill country }\end{array}$ & $\begin{array}{l}\text { Economically viable option but } \\
\text { long term sustainability not } \\
\text { confirmed }\end{array}$ & $\begin{array}{l}\text { Lambert et al. } 2003 \text { - NZGA } \\
\text { Vol. } 65\end{array}$ \\
\hline $\begin{array}{l}\text { Combining genetics, good } \\
\text { milk production and pasture } \\
\text { growth rates }\end{array}$ & $\begin{array}{l}\text { Best practice individual and mob } \\
\text { live weight gains }\end{array}$ & $\begin{array}{l}\text { Muir et al. } 2003 \text { - NZGA Vol. } \\
65\end{array}$ \\
\hline $\begin{array}{l}\text { Growing ryegrass and white } \\
\text { clovers separately }\end{array}$ & $\begin{array}{l}\text { Higher average daily weight } \\
\text { gains of lambs and hoggets }\end{array}$ & $\begin{array}{l}\text { Cosgrove et al. } 2003 \text { - NZGA } \\
\text { Vol. } 65\end{array}$ \\
\hline AR1 endophyte for dairying & $\begin{array}{l}\text { Higher milksolids production } \\
\text { compared to wild type } \\
\text { endophyte }\end{array}$ & $\begin{array}{l}\text { Bluett et al. } 2003 \text { - NZGA Vol. } \\
65\end{array}$ \\
\hline
\end{tabular}




\begin{tabular}{|c|c|c|}
\hline Technology/advance & Impact/significance & Date - NZGA Proceedings \\
\hline $\begin{array}{l}\text { "Standing off" pasture } \\
\text { management in winter }\end{array}$ & Reduced pugging & Drewry 2003 - NZGA Vol. 65 \\
\hline $\begin{array}{l}\text { Soil P movement greater in } \\
\text { low anion storage capacity } \\
\text { soils }\end{array}$ & $\begin{array}{l}\text { Impact on } \mathrm{P} \text { enrichment of water } \\
\text { bodies }\end{array}$ & $\begin{array}{l}\text { Morton et al. } 2003 \text { - NZGA } \\
\text { Vol. } 65\end{array}$ \\
\hline $\begin{array}{l}\text { Lifting maize populations } \\
\text { from } 115,000 \text { to } 130,000 \\
\text { plants per ha }\end{array}$ & $\begin{array}{l}\text { Profitable increase in maize } \\
\text { yields }\end{array}$ & $\begin{array}{l}\text { Densley et al. } 2003 \text { - NZGA } \\
\text { Vol. } 65\end{array}$ \\
\hline $\begin{array}{l}\text { Integrating winter and } \\
\text { summer crops and } \\
\text { minimising } \mathrm{N} \text { leaching }\end{array}$ & $\begin{array}{l}\text { Increased yields without } \\
\text { increasing } \mathrm{N} \text { leaching }\end{array}$ & $\begin{array}{l}\text { Judge et al. } 2003 \text { - NZGA Vol. } \\
65\end{array}$ \\
\hline $\begin{array}{l}\text { Isotopic composition of cow } \\
\text { tail switch hair }\end{array}$ & $\begin{array}{l}\text { Information archive of animal } \\
\text { environment }\end{array}$ & $\begin{array}{l}\text { Schwertl et al. } 2003 \text { - NZGA } \\
\text { Vol. } 65\end{array}$ \\
\hline Red clover & Tolerant of clover root weevil & $\begin{array}{l}\text { Cooper et al. } 2003 \text { - NZGA } \\
\text { Vol. } 65\end{array}$ \\
\hline $\begin{array}{l}\text { Grasslands Tribute white } \\
\text { clover }\end{array}$ & $\begin{array}{l}\text { Medium large leaved cultivar } \\
\text { with wide adaptation }\end{array}$ & $\begin{array}{l}\text { Woodfield et al. } 2003 \text { - NZGA } \\
\text { Vol. } 65\end{array}$ \\
\hline DNA finger printing & $\begin{array}{l}\text { Application for identification of } \\
\text { white clover cultivars }\end{array}$ & $\begin{array}{l}\text { Jahufer et al. } 2003 \text { - NZGA } \\
\text { Vol. } 65\end{array}$ \\
\hline Deferred effluent irrigation & Reduced leaching of nutrients & $\begin{array}{l}\text { Houlbrooke et al. } 2003 \text { - NZGA } \\
\text { Vol. } 65\end{array}$ \\
\hline Life cycle assessment & $\begin{array}{l}\text { Whole system approach to } \\
\text { resource use and environmental } \\
\text { emissions }\end{array}$ & $\begin{array}{l}\text { Ledgard et al. } 2003 \text { - NZGA } \\
\text { Vol. } 65\end{array}$ \\
\hline OVERSEER nutrient budgets & On-farm resource accounting & $\begin{array}{l}\text { Wheeler et al. } 2003 \text { - NZGA } \\
\text { Vol. } 65\end{array}$ \\
\hline $\begin{array}{l}\text { Cocksfoot in ryegrass } \\
\text { pastures }\end{array}$ & $\begin{array}{l}\text { Reduced incidence of ryegrass } \\
\text { staggers }\end{array}$ & $\begin{array}{l}\text { Hyslop et al. } 2003 \text { - NZGA } \\
\text { Vol. } 65\end{array}$ \\
\hline $\begin{array}{l}\text { Differential fertiliser } \\
\text { application }\end{array}$ & $\begin{array}{l}\text { More accurate application of } \\
\text { fertiliser }\end{array}$ & $\begin{array}{l}\text { Gillingham et al. } 2003 \text { - NZGA } \\
\text { Vol. } 65\end{array}$ \\
\hline Maintaining soil structure & $\begin{array}{l}\text { Nitrous oxide emissions } \\
\text { increased with increased soil } \\
\text { compaction }\end{array}$ & $\begin{array}{l}\text { Bhandral et al. } 2003 \text { - NZGA } \\
\text { Vol. } 65\end{array}$ \\
\hline $\begin{array}{l}\text { High levels of specific } \\
\text { flavonoids in clover }\end{array}$ & Increased UV-B stress tolerance & $\begin{array}{l}\text { Hoffman et al. } 2003 \text { - NZGA } \\
\text { Vol. } 65\end{array}$ \\
\hline Groundwater allocation & $\begin{array}{l}\text { Management of water resources } \\
\text { for irrigated farming }\end{array}$ & $\begin{array}{l}\text { Miller \& Veltman } 2004 \text { - NZGA } \\
\text { Vol. } 66\end{array}$ \\
\hline $\begin{array}{l}\text { Improving grazing } \\
\text { management to reduce dead } \\
\text { material reduces lime } \\
\text { requirement to lower Mn } \\
\text { levels in herbage below the } \\
\text { animal health threshold }\end{array}$ & $\begin{array}{l}\text { Less lime required to lower } \mathrm{Mn} \\
\text { in herbage }\end{array}$ & $\begin{array}{l}\text { Smith et al. } 2004 \text { - NZGA Vol. } \\
66\end{array}$ \\
\hline Whole crop cereal silages & $\begin{array}{l}\text { An alternative for supplementing } \\
\text { pasture silage }\end{array}$ & $\begin{array}{l}\text { Stevens et al. } 2004 \text { - NZGA } \\
\text { Vol. } 66\end{array}$ \\
\hline $\begin{array}{l}\text { Integrating multi-graze crops } \\
\text { with summer legume/cereal } \\
\text { crop }\end{array}$ & $\begin{array}{l}\text { Achieve an excess of } 25 \mathrm{t} / \text { ha dry } \\
\text { matter per year }\end{array}$ & $\begin{array}{l}\text { Fraser et al. } 2004 \text { - NZGA Vol. } \\
66\end{array}$ \\
\hline $\begin{array}{l}\text { Plant growth regulators and } \\
\text { new generation fungicides }\end{array}$ & $\begin{array}{l}\text { Improved seed yields of ryegrass } \\
\text { and tall fescue }\end{array}$ & $\begin{array}{l}\text { Rolston et al. } 2004 \text { - NZGA } \\
\text { Vol. } 66\end{array}$ \\
\hline $\begin{array}{l}\text { Direct drilling winter forages } \\
\text { crops and avoid grazing on } \\
\text { wet soils }\end{array}$ & Reduced nitrous oxide emission & $\begin{array}{l}\text { Thomas et al. } 2004 \text { - NZGA } \\
\text { Vol. } 66\end{array}$ \\
\hline
\end{tabular}




\begin{tabular}{|c|c|c|}
\hline Technology/advance & Impact/significance & Date - NZGA Proceedings \\
\hline $\begin{array}{l}\text { Reduce volume of irrigation } \\
\text { run-off }\end{array}$ & $\begin{array}{l}\text { Reduced loss of nutrients and } \\
\text { faecal bacteria to waterways }\end{array}$ & $\begin{array}{l}\text { Carey et al. } 2004 \text { - NZGA Vol. } \\
66\end{array}$ \\
\hline $\begin{array}{l}\text { Increasing proportion of } \\
\text { clover in diet }\end{array}$ & $\begin{array}{l}\text { Reduced methane per } \mathrm{kg} \\
\text { milksolids and increased } \\
\text { milksolids production }\end{array}$ & Lee et al. 2004 - NZGA Vol. 66 \\
\hline $\begin{array}{l}\text { Protocol for turnip } \\
\text { production }\end{array}$ & Higher yields & $\begin{array}{l}\text { Eerens \& Lane } 2004 \text { - NZGA } \\
\text { Vol. } 66\end{array}$ \\
\hline Forage Master & $\begin{array}{l}\text { A decision tool for selecting and } \\
\text { managing forages for sheep and } \\
\text { beef farms }\end{array}$ & $\begin{array}{l}\text { Finlayson et al. } 2004 \text { - NZGA } \\
\text { Vol. } 66\end{array}$ \\
\hline High floral tannin clover & $\begin{array}{l}\text { Reduced rumen ammonia } \\
\text { concentrations }\end{array}$ & $\begin{array}{l}\text { Burggraaf et al. } 2004 \text { - NZGA } \\
\text { Vol. } 66\end{array}$ \\
\hline Chicory and plantain & Natrophiles that provide high $\mathrm{Na}$ & $\begin{array}{l}\text { Aspinall et al. } 2004 \text { - NZGA } \\
\text { Vol. } 66\end{array}$ \\
\hline Kieserite $-\mathrm{MgSO} 4$ & $\begin{array}{l}\text { Quicker acting } \mathrm{Mg} \text { fertiliser than } \\
\mathrm{MgO}\end{array}$ & $\begin{array}{l}\text { O'Connor et al. } 2004 \text { - NZGA } \\
\text { Vol. } 66\end{array}$ \\
\hline $\begin{array}{l}\text { Modifying forage lipid } \\
\text { concentration and fatty acid } \\
\text { profile }\end{array}$ & $\begin{array}{l}\text { Feed-sparing effect and } \\
\text { improved human health effects } \\
\text { (in meat) }\end{array}$ & $\begin{array}{l}\text { Cosgrove et al. } 2004 \text { - NZGA } \\
\text { Vol. } 66\end{array}$ \\
\hline High sugar grasses & $\begin{array}{l}\text { Low temperatures required to } \\
\text { stimulate high water soluble } \\
\text { carbohydrates in harvestable } \\
\text { components of ryegrass }\end{array}$ & $\begin{array}{l}\text { Parsons et al. } 2004 \text { - NZGA } \\
\text { Vol. } 66\end{array}$ \\
\hline $\begin{array}{l}\text { Crop before grass sowing } \\
\text { and parasitoid }\end{array}$ & $\begin{array}{l}\text { Reduced impact of clover root } \\
\text { weevil }\end{array}$ & $\begin{array}{l}\text { Eerens et al. } 2005 \text { - NZGA Vol. } \\
67\end{array}$ \\
\hline $\begin{array}{l}\text { Vigorous white clovers and } \\
\text { red clover }\end{array}$ & $\begin{array}{l}\text { Improved tolerance of clover } \\
\text { root weevil }\end{array}$ & $\begin{array}{l}\text { Crush et al. } 2005 \text { - NZGA Vol. } \\
67\end{array}$ \\
\hline $\begin{array}{l}\text { Nematode resistant white } \\
\text { clover selections }\end{array}$ & $\begin{array}{l}\text { Improved ability to withstand } \\
\text { nematodes }\end{array}$ & $\begin{array}{l}\text { Mercer et al. } 2005 \text { - NZGA Vol. } \\
67\end{array}$ \\
\hline Soil consolidation & $\begin{array}{l}\text { Improved white clover } \\
\text { establishment }\end{array}$ & $\begin{array}{l}\text { Brock et al. } 2005 \text { - NZGA Vol. } \\
67\end{array}$ \\
\hline Maize silage & $\begin{array}{l}\text { Improved milksolids production } \\
\text { and depending on payout } \\
\text { improved profitability }\end{array}$ & $\begin{array}{l}\text { Dalley et al. } 2005 \text { - NZGA Vol. } \\
67\end{array}$ \\
\hline Dairy Systems Monitoring & $\begin{array}{l}\text { Extension tool to highlight the } \\
\text { impact of new technologies or } \\
\text { management practices }\end{array}$ & $\begin{array}{l}\text { Savage \& Lewis } 2005 \text { - NZGA } \\
\text { Vol. } 67\end{array}$ \\
\hline $\begin{array}{l}\text { Roller drill and double } \\
\text { sowing rates }\end{array}$ & $\begin{array}{l}\text { Improved establishment when } \\
\text { sowing into flood damaged } \\
\text { pastures }\end{array}$ & $\begin{array}{l}\text { Wilson \& Valentine } 2005 \text { - } \\
\text { NZGA Vol. } 67\end{array}$ \\
\hline $\begin{array}{l}\text { Timothy/white clover } \\
\text { pastures }\end{array}$ & $\begin{array}{l}\text { Improved milksolids production } \\
\text { on irrigated soils free of } \\
\text { Argentine stem weevil }\end{array}$ & $\begin{array}{l}\text { Thomson \& Kay } 2005 \text { - NZGA } \\
\text { Vol. } 67\end{array}$ \\
\hline $\begin{array}{l}\text { Maize sowing between } 15 \\
\text { and } 24 \text { October }\end{array}$ & Improved yields in Taranaki & $\begin{array}{l}\text { Densley et al. } 2005 \text { - NZGA } \\
\text { Vol. } 67\end{array}$ \\
\hline $\begin{array}{l}\text { Paddock feed out rate of } 4 \mathrm{~kg} \\
\text { silage DM per linear } \mathrm{m}\end{array}$ & Reduced waste & $\begin{array}{l}\text { Stevens \& Platfoot } 2005 \text { - } \\
\text { NZGA Vol. } 67\end{array}$ \\
\hline Conventional maize hybrids & $\begin{array}{l}\text { More milksolids and profit per } \\
\text { ha than when using leafy maize } \\
\text { hybrids }\end{array}$ & $\begin{array}{l}\text { Densley et al. } 2005 \text { - NZGA } \\
\text { Vol. } 67\end{array}$ \\
\hline AR542 endophyte & $\begin{array}{l}\text { Increased resistance of tall } \\
\text { fescue to Argentine stem weevil } \\
\text { and black beetle }\end{array}$ & $\begin{array}{l}\text { Popay et al. } 2005 \text { - NZGA Vol. } \\
67\end{array}$ \\
\hline
\end{tabular}

